Mauren Fernanda Moller dos Santos

\title{
Estudo genético de síndromes associadas à obesidade
}

Dissertação apresentada ao Instituto de Biociências da Universidade de São Paulo, para a obtenção de Título de Mestre em Biologia/Genética.

São Paulo 
Mauren Fernanda Moller dos Santos

\section{Estudo genético de síndromes associadas à obesidade}

Dissertação apresentada ao Instituto de Biociências da Universidade de São Paulo, para a obtenção de Título de Mestre em Biologia/Genética.

Orientadora: Profa. Dra. Celia P. Koiffmann

São Paulo 


\begin{tabular}{|} 
Santos, Mauren Fernanda Moller dos \\
Estudo genético de síndromes associadas à obesidade \\
174 pág. \\
Dissertação de Mestrado - Instituto de Biociências da \\
Universidade de São Paulo. Departamento de Genética e \\
Biologia Evolutiva. \\
1 - Obesidade e/ou Hiperfagia \\
2 - Atraso do desenvolvimento neuropsicomotor \\
3 - Distúrbios de comportamento \\
$4-$ SNP-array \\
$5-$ Array-CGH \\
6 - Variação do número de cópias (CNV)
\end{tabular}

\section{Comissão Julgadora}

Profa. Dra. Celia P. Koifmann

Orientadora 


\section{AGRADECIMENTOS}

À Dra. Celia P. Koiffmann, pela oportunidade de participar de seu laboratório, pelos ensinamentos, por ter confiado em meu trabalho e pela sua paciência.

Às Dras. Carla Rosenberg, Debora Bertola e Regina Célia Mingroni Netto, que participaram da minha qualificação e pelas suas sugestões.

Aos pacientes e seus familiares que contribuíram para este trabalho, tornando possível o avanço dos estudos nesta área do conhecimento.

À Cláudia, Carla, Amanda, Cris, Estela, Rose, Monica e Luceleni, por me ajudarem sempre que preciso, pela amizade e risadas. Especialmente à Cláudia por me ensinar citogenética e possibilitar que eu continue trabalhando com isso e à Carla pela grande colaboração nas técnicas e análises e pelas revisões de texto.

Aos colegas do Departamento de Genética e Biologia Evolutiva e do Genoma pelas colaborações e empréstimo de materiais, principalmente à Simone, do laboratório da Dra. Maria Rita S. e Passos Bueno, e à Silvia, do laboratório da Dra. Carla Rosenberg, por me ensinarem e auxiliarem nas técnicas de arrays.

Aos meus pais, ao Thiago, aos familiares e amigos que apoiaram e de alguma forma contribuíram para a realização deste trabalho. 


\section{ÍNDICE}

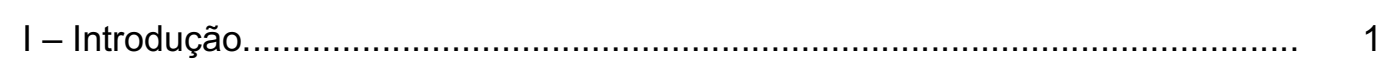

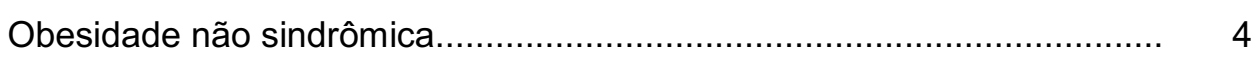

Obesidade monogênica..................................................... 4

Deficiência da leptina ou do receptor de leptina................ 5

Deficiência de pro-opiomelanocortina.............................. 6

Deficiência do receptor-4 de melanocortina...................... 8

Gene FTO..................................................... 8

Obesidade sindrômica................................................................. 9

Síndrome de Prader-Willi...................................................... 9

Síndromes associadas à obesidade e/ou hiperfagia..................... 10

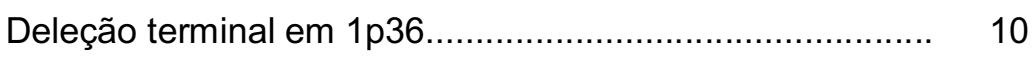

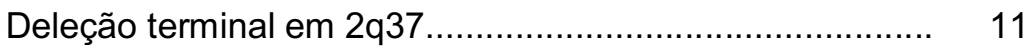

Deleção em 6q16.2 e haploinsuficiência do gene SIM1...... 12

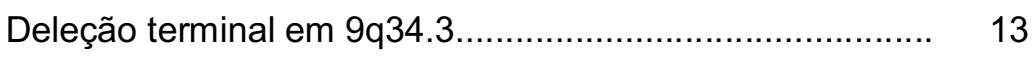

Síndrome de WAGR ................................................. 14

Síndrome de Smith-Magenis........................................ 15

Síndrome de Bardet-Bield........................................... 16

Hibridação Genômica Comparativa baseada em arrays........................ 17

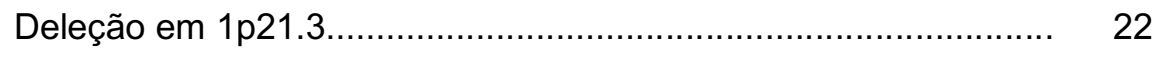

Deleção em 2p25.3............................................................ 22

Translocação não equilibrada entre os cromossomos 8 e 12 -

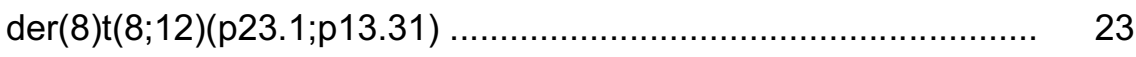

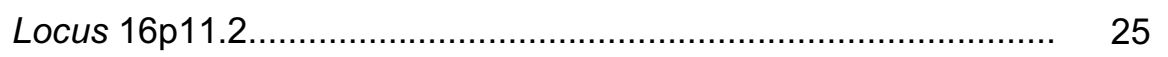

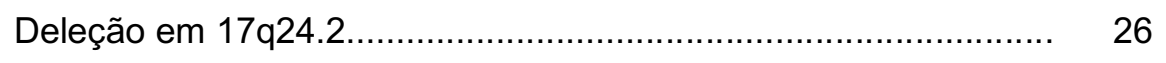




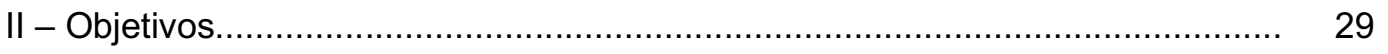

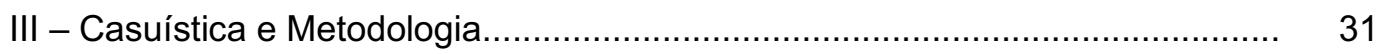

Casuística................................................................................. 32

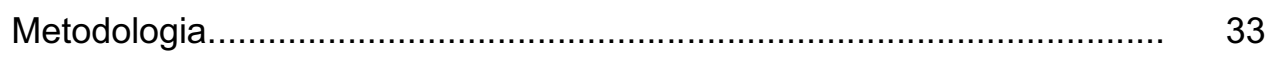

Cultura de linfócitos de sangue periférico.................................. 34

Análise cromossômica por bandamento GTG............................ $\quad 36$

Análise citogenética molecular por FISH (fluorescence in situ

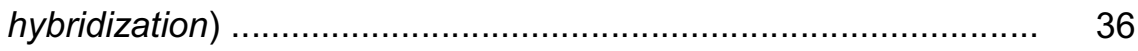

Quantitative polymerase chain reaction (qPCR) ....................... 38

IV - Resultados e Discussão...................................................................... 40

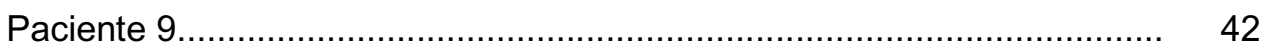

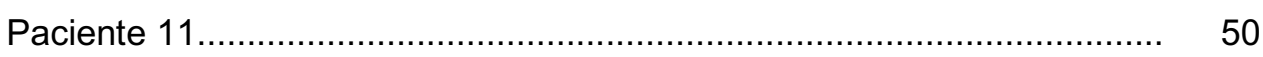

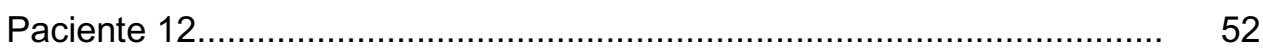

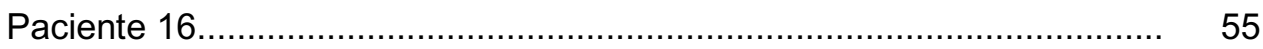

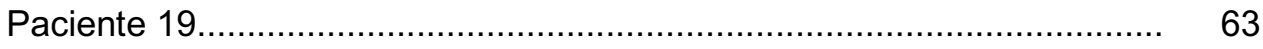

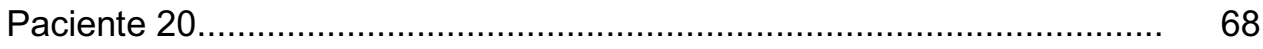

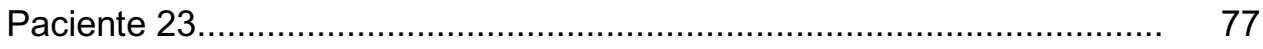

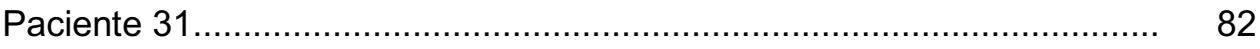

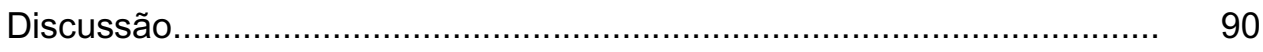

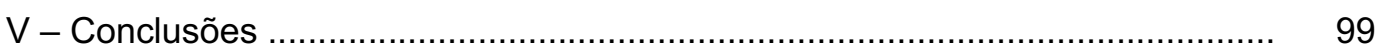

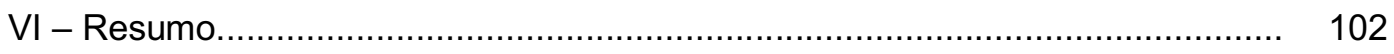

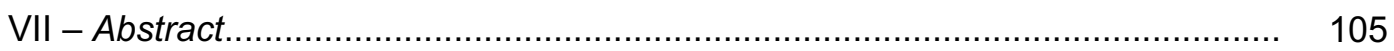

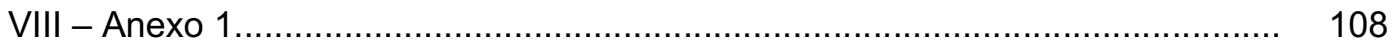

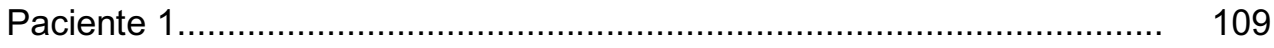

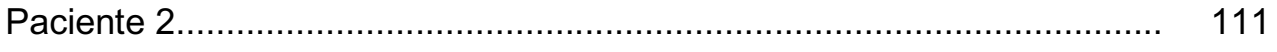

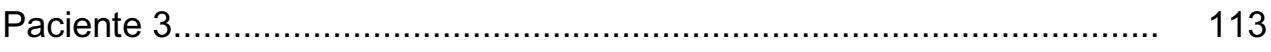

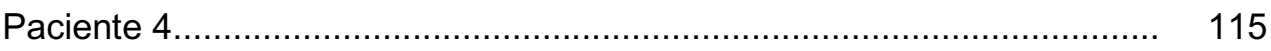




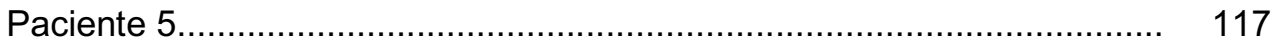

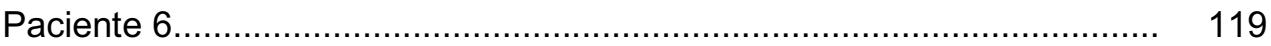

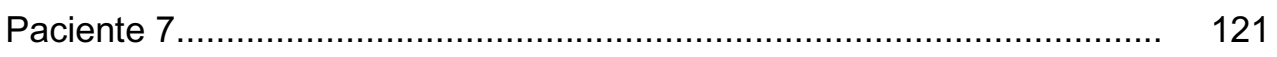

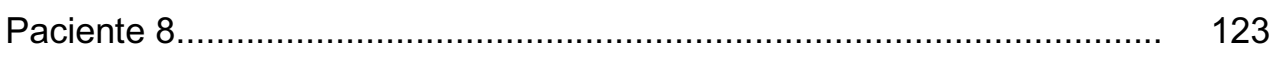

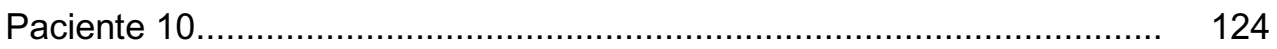

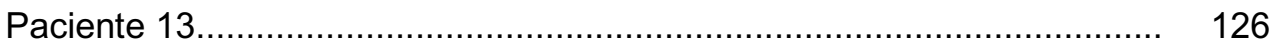

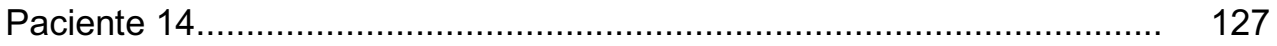

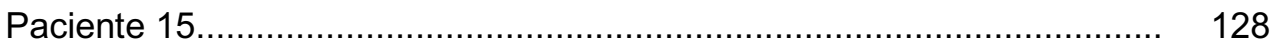

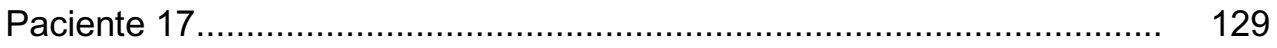

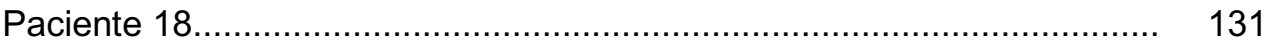

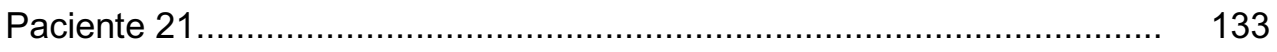

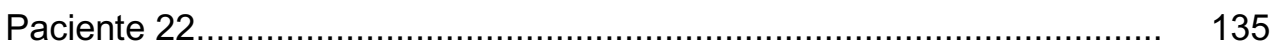

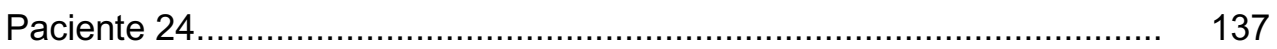

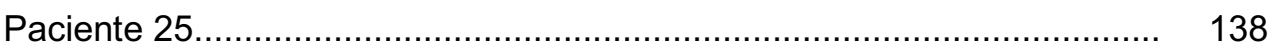

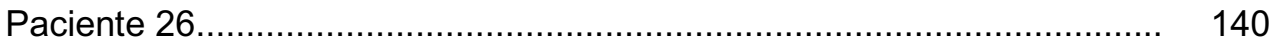

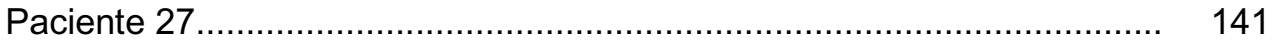

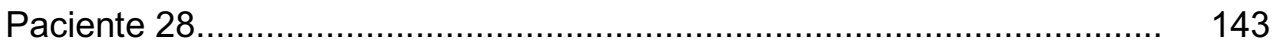

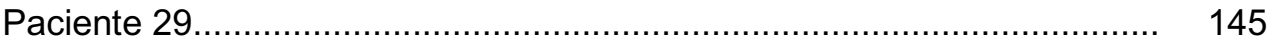

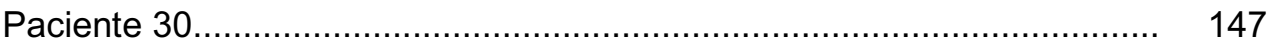

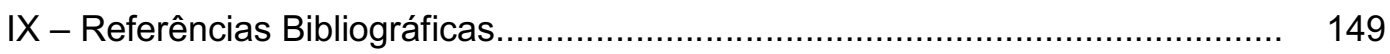

Referências Eletrônicas................................................................... 150

Referências Bibliográficas............................................................... 151 


\section{Introdução}




\section{I - Introdução}

A obesidade se tornou uma das maiores preocupações de saúde pública, aumentando a taxa de mortalidade e o risco de morbidade entre os casos de hipertensão, dislipidemia, diabetes mellitus e doenças cardiovasculares (Calton et al., 2009). De acordo com a Organização Mundial de Saúde (OMS), em 2005, a estimativa de adultos com sobrepeso (IMC > $25 \mathrm{~kg} / \mathrm{m}^{2}$ ) era de 1,6 bilhões de indivíduos e de adultos obesos $\left(\mathrm{IMC}>30 \mathrm{~kg} / \mathrm{m}^{2}\right.$ ) 400 milhões de indivíduos. Já a estimativa para as crianças menores que 5 anos era de 20 milhões com sobrepeso. Além disso, a OMS calcula que em 2015 haverá aproximadamente 2,3 bilhões de adultos com sobrepeso e mais de 700 milhões de obesos.

O índice de massa corporal (IMC) é uma das principais medidas antropométricas utilizadas em estudos sobre obesidade, e é calculado pela divisão do peso do indivíduo em quilogramas pelo quadrado da altura em metros (Bell et al., 2005).

Tabela 1 - A Classificação Internacional do IMC para indivíduos adultos

\begin{tabular}{|c|c|}
\hline Classificação & IMC $\left(\mathrm{kg} / \mathrm{m}^{2}\right)$ \\
\hline Muito abaixo do peso & Abaixo de 17 \\
\hline Abaixo do peso & Entre 17 e 18,49 \\
\hline Peso normal & Entre 18,5 e 24,99 \\
\hline Sobrepeso & Entre 25 e 29,99 \\
\hline Obesidade I & Entre 30 e 34,99 \\
\hline Obesidade II (severa) & Entre 35 e 39,99 \\
\hline Obesidade III (mórbida) & Acima de 40 \\
\hline
\end{tabular}

Adaptado de OMS (http://apps.who.int/bmi/index.jsp?introPage=intro_3.html) 
Diversos autores, como Bell et al. (2005), Mutch et al. (2006), Barness et al. (2007) e Calton et al. (2009), definem a obesidade como resultado da ingestão de calorias em excesso e um baixo gasto energético. Este último devido, inclusive, ao estilo de vida sedentário adotado pelas populações ocidentais. Apesar disso, Barness et al. (2007) referem que a atividade física representa apenas cerca de $10 \%$ da utilização da energia total em um adulto médio e, embora a diminuição da capacidade de exercício possa acompanhar a obesidade, falta de exercício físico não necessariamente resulta em obesidade.

Existem os fatores genéticos que também estão envolvidos no ganho de peso, de forma que os indivíduos que geneticamente tem uma susceptibilidade ao ganho de peso, em um ambiente obesogênico acabam se tornando excessivamente obesos. (Bell et al., 2005).

Estudos realizados no final dos anos 80 e início dos anos 90 com gêmeos e crianças adotadas indicaram que $80 \%$ da variação do IMC é atribuída a fatores genéticos (Bouchard et al., 1990,1994). Outros estudos baseados na composição corporal de gêmeos criados separados e estudos comparando a composição corporal de crianças adotadas com seus pais biológicos e com seus pais adotivos também sugerem forte influência genética sobre a composição corporal e distribuição da gordura (Barness et al., 2007).

A obesidade é um distúrbio neuroendócrino no qual fatores ambientais e a predisposição genética agem em conjunto (Hebebrand, 2007; Hebebrand et al, 2003, Hebebrand \& Hinney, 2009). A última atualização do Human obesity gene Map, publicada em 2006, apresentou 127 genes candidatos, resultado de 426 associações positivas com o fenótipo obesidade. 
A obesidade é, portanto, considerada uma doença multifatorial que envolve uma complexa interação entre componentes genéticos e influências ambientais, levando ao excesso de armazenamento de energia na forma de gordura corporal. A modulação da quantidade de energia que ingerimos envolve os mecanismos neurofisiológicos que conectam o cérebro com o intestino e possivelmente a outros sistemas que regulam a homeostase energética e o comportamento alimentar (Kousta et al., 2009).

Diferentes estratégias têm sido utilizadas para abordar os determinantes genéticos da obesidade, incluindo estudos de associação, análises de varredura genômica (genome-wide scan), o estudo das formas monogênicas de obesidade e o estudo de síndromes genéticas com anomalias do desenvolvimento associadas à obesidade (Kousta et al., 2009).

Centenas de estudos dos últimos 15 anos têm sugerido uma associação positiva das variantes comuns de um grande número de genes candidatos com fenótipos de obesidade ou relacionados a ela, porém os efeitos dessas variantes explicam apenas uma pequena porcentagem da variação no peso e IMC. Isso indica que a susceptibilidade à obesidade em humanos pode ser resultado dos efeitos aditivos das variantes genéticas comuns, de diferentes mutações raras em um grande conjunto de genes, ou da combinação de ambos, além dos efeitos do ambiente (Calton et al., 2009; Hinney et al., 2010).

\section{Obesidade não sindrômica}

\section{Obesidade monogênica}

Mutações em genes que codificam proteínas com provável função na regulação de apetite são responsáveis por doenças mendelianas em que a 
obesidade é o fenótipo mais evidente (Bell et al., 2005). Estudos sobre formas monogênicas de obesidade revelaram diversos genes e mutações envolvidos no equilíbrio de energia, fornecendo entendimento sobre alguns dos mecanismos relacionados à regulação do peso corporal (Kousta et al., 2009).

Mutações nos genes da leptina (LEP), receptor da leptina (LEPR), proopiomelanocortina (POMC), pró-hormônio convertase e receptor-4 de melanocortina (MC4R), afetam a regulação do apetite resultando em um fenótipo de obesidade grave devido à hiperfagia, indicando que estas vias são criticamente importantes na regulação do peso e adiposidade em seres humanos (Barness et al., 2007) (Figura1).

\section{Deficiência da leptina ou do receptor de leptina}

O hormônio anorexigênico leptina parece ser o principal indicador da adiposidade e do sinal do estado de nutrição, pois seus níveis no plasma são altamente correlacionados ao número de adipócitos e ao teor de gordura. Esse papel pode ser observado pela reposição de leptina em uma criança de 9 anos extremamente obesa com deficiência congênita de leptina. A injeção subcutânea diária de leptina recombinante humana por um ano levou a uma reversão completa da obesidade, com perda de massa gorda (Bell et al., 2005).

O gene da leptina está localizado em 7q31.3, enquanto que o gene do receptor de leptina está em 1p31 (Beales et al., 2009). A deficiência em qualquer um dos genes resulta no aumento do peso, sendo que os pacientes apresentam peso normal ao nascimento, porém nos primeiros meses de vida ocorre rápido ganho de peso, levando a obesidade grave. Quando a leptina não é detectada no soro há uma grande possibilidade de se diagnosticar a 
deficiência congênita de leptina, decorrente da homozigose do gene mutado que leva à perda de função do gene. A mutação no gene do receptor de leptina resulta em um processamento (splicing) anormal do RNAm, gerando um receptor sem os domínios transmembrânico e intracelular. Assim, o receptor mutante circula em alta concentração, vinculado à leptina, levando a uma elevada concentração de leptina no soro.

\section{Deficiência de pro-opiomelanocortina}

O gene da pro-opiomelanocortina (POMC), localizado na região cromossômica 2p23.3, é transcrito em vários tecidos, incluindo as células corticotróficas da hipófise anterior, os neurônios do núcleo arqueado do hipotálamo e as células na derme e do sistema linfático. Em todos estes tipos de células POMC sofre um processamento pós-traducional que resulta em uma série de peptídeos menores (Coll et al., 2004).

Krude et al. (2009) citam que em dois estudos de ligação cobrindo todo o genoma o locus do gene POMC estava ligado com a ocorrência de fenótipos obesos. A triagem das mutações na região codificante do gene falhou em detectar alterações associadas ao fenótipo obeso, de maneira que os autores concluíram que mudanças na região não codificante devem existir e interferem na expressão apropriada do gene POMC. Devido às suas diversas funções, defeitos no gene resultam em uma doença complexa, com deficiência de corticotropina, obesidade severa de início precoce e hipopigmentação. 


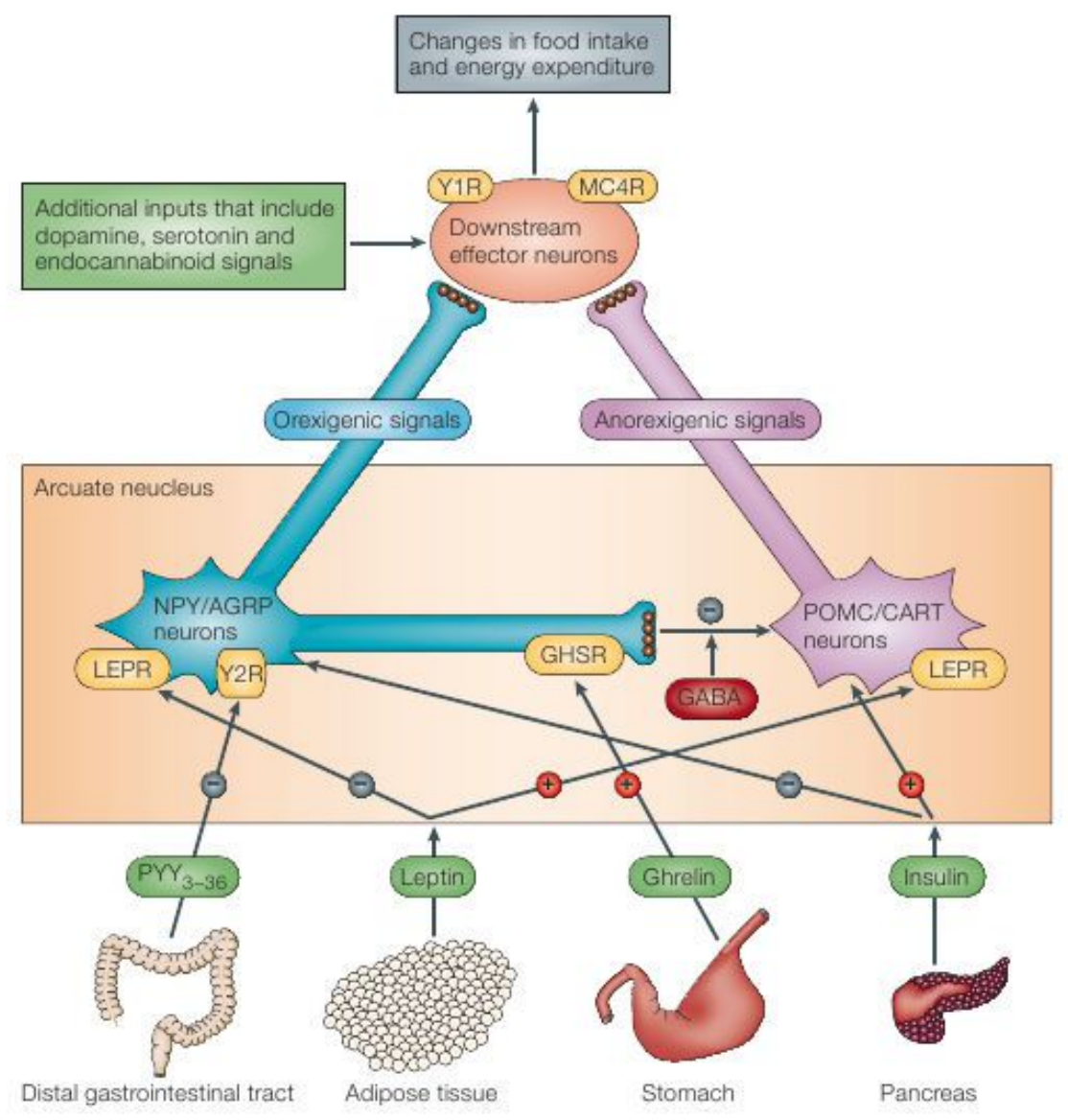

Figura 1 - Regulação fisiológica do balanço energético.

Os neurônios produtores de neuropeptídeo Y (NPY) / proteína relacionada a agouti (AGRP) e os neurônios produtores de pro-opiomelanocortina $(\mathrm{POMC}) /$ transcrito relacionado à cocaína e anfetamina (CART) no núcleo arqueado do hipotálamo têm uma função chave na regulação do balanço energético. A ativação dos neurônios NPY/AGRP tem efeito orexigênico, promovendo a ingestão de alimento, enquanto que a ativação dos neurônios POMC/CART tem o efeito oposto anorexigênico. A POMC é ativada através de modificação pós-traducional dando origem ao hormônio melanócito-estimulante alfa ( $\alpha-\mathrm{MSH}$, não mostrado). Essas duas classes de neurônios recebem sinais de vários hormônios. A leptina é secretada pelo tecido adiposo, circulando em níveis que são proporcionais às reservas de gordura corporal e exerce seu efeito através de seu receptor (LEPR), inibindo os neurônios NPY/AGRP e estimulando os neurônios POMC/CART. O pâncreas secreta a insulina, que tem influência anorexigênica sobre o núcleo arqueado. A grelina é produzida pelo estômago e duodeno, e estimula os neurônios NPYIAGRP através de seus receptores secretagogos de hormônio de crescimento (GHSRs). O peptídeo YY3-36 (PYY3-36) é secretado pelo trato gastrointestinal distal e sinaliza através dos receptores Y2 (Y2Rs) a produção de um efeito inibitório sobre os neurônios NPY/AGRP. Os neurônios NPY/AGRP também têm um efeito inibitório sobre os neurônios POMC/CART através da liberação do ácido $\gamma$-aminobutírico (GABA), que pode ser estimulado pela ligação da grelina aos GHSRs. Os sinais orexigênicos e anorexigênicos produzidos pelos neurônios NPYIAGRP e POMC/CART são então enviados até neurônios efetores de segunda ordem, que também recebem sinais modificadores da dopamina, serotonina e endocanabinóides. Esses neurônios efetores expressam receptores que incluem o receptor $\mathrm{Y} 1$ (Y1R) e o receptor-4 de melanocortina (MC4R). Esses diversos sinais atuam juntos para proporcionar o total equilíbrio entre a aquisição de alimento e o gasto energético. (Modificado de Bell et al., 2005). 


\section{Deficiência do receptor-4 de melanocortina}

A forma de obesidade de herança autossômica dominante mais freqüente é causada por mutações no gene que codifica o receptor-4 de melanocortina (MC4R), localizado na região 18q22 (Bell et al., 2005; Mutch et al., 2006). Está presente em 1-6\% dos indivíduos obesos de diferentes grupos étnicos, com maior prevalência em casos de maior gravidade e idade de início precoce.

Os pacientes apresentam um acelerado crescimento linear e hiperinsulinemia precoce, além de pressão arterial baixa. Também apresentam hiperfagia, mas não tão grave como a observada na deficiência de leptina (Farooqi et al., 2009).

Camundongos com deficiência em MC4R não são hiperfágicos ao serem alimentados com uma dieta pobre em gordura, porém a hiperfagia é observada após a introdução de um maior teor de gordura, indicando interações geneambiente.

\section{Gene FTO}

Recentemente, pesquisadores britânicos descobriram um gene (FTO) presente no cromossomo 16q12.2, que está fortemente associado com o controle de índice de massa corporal. Os $16 \%$ dos adultos que são homozigotos para o alelo de risco pesavam cerca de $3 \mathrm{~kg}$ a mais e tiveram um risco 1,67 vezes maior de obesidade, quando comparados com aqueles que não herdaram o alelo de risco (Barness et al., 2007). Outros pesquisadores testaram 48 SNPs em diferentes regiões intergênicas para estimar a distribuição de SNPs neutros em sua amostra de caso-controle para 
obesidade. Eles observaram associação entre SNPs no primeiro íntron de FTO e um aumento no risco de obesidade (Beales et al., 2009).

\section{Obesidade sindrômica}

Há entre 20 e 30 doenças herdadas de forma Mendeliana nas quais os pacientes são clinicamente obesos e também apresentam deficiência intelectual, características dismórficas e anomalias do desenvolvimento de órgãos específicos (Mutch et al., 2006). Somente algumas dessas síndromes, tais como Prader-Willi, Bardet-Biedl, Alström, Cohen, WAGR (tumor de Wilms, aniridia, anomalias genitourinárias e deficiência intelectual) estão associadas à obesidade de início precoce (Choquet et al., 2010).

A obesidade nestas síndromes parece envolver defeitos estruturais e/ou funcionais do hipotálamo que estão relacionados ao comportamento alimentar e a liberação de insulina, porém os mecanismos fisiopatológicos exatos não são totalmente conhecidos. (Barness et al., 2007).

\section{Síndrome de Prader-Willi}

A síndrome de Prader-Willi (PWS) é a mais freqüente das síndromes que possui a obesidade como uma de suas características, com incidência de 1:25.000 nascimentos. É caracterizada por hipotonia neonatal com dificuldade de sucção, atraso do desenvolvimento neuropsicomotor (DNPM), hiperfagia, obesidade, baixa estatura em adolescentes, mãos e pés pequenos, hipogonadismo, distúrbios do sono, características faciais dismórficas, deficiência intelectual leve a moderada e comportamento obsessivo-compulsivo (Varela et al., 2005; Kousta et al., 2009). 
O segmento 15q11-q13 está relacionado ao imprinting genômico, sendo que vários genes nesta região são ativos apenas no cromossomo herdado do pai, enquanto outro(s) gene(s) é ativo apenas no cromossomo herdado da mãe. A PWS é uma das doenças humanas que está relacionada ao imprinting e resulta da ausência de expressão de genes ativos no cromossomo paterno. A perda dos genes ativos herdados paternamente contribui para o fenótipo completo da síndrome de Prader-Willi, no entanto, a ausência de um pequeno RNA organizador nucleolar (snoRNA), SNORD116 (HBII-85), parece produzir muitas das características clínicas, como hipotonia neonatal, obesidade mórbida de início precoce e hipogonadismo (Cassidy et al., 2012).

Existem três mecanismos genéticos que resultam na síndrome de Prader-Willi. O principal deles é a deleção paterna dentro do segmento 15q11q13, que ocorre em aproximadamente $70 \%$ dos casos. A dissomia uniparental materna (UPD) do cromossomo 15 ocorre em aproximadamente $25 \%$ dos casos e em torno de $2 \%$ dos pacientes têm um defeito no centro de imprinting. No caso da deleção, existem 5 tipos dependendo dos pontos de quebra, sendo que os dois mais encontrados são o tipo I, com pontos de quebra em BP1 e BP3, e o tipo II, com pontos de quebra em BP2 e BP3 (Varela et al., 2005).

\section{Síndromes associadas à obesidade e/ou hiperfagia \\ Deleção terminal em $1 p 36$}

Rearranjos subteloméricos ocorrem em aproximadamente $5 \%$ dos pacientes com deficiência intelectual idiopática, sendo que a deleção terminal de $1 p$ é a mais comum, tendo uma incidência estimada de 1:5.000 (D'Angelo et al., 2006). 
A síndrome da deleção de 1 p36 tem como características atraso no DNPM e/ou deficiência intelectual, hipotonia, perda auditiva, epilepsia, microcefalia, braquicefalia, olhos fundos, ponte nasal baixa, cardiomiopatias, dificuldades de alimentação na infância e alguns pacientes possuem obesidade e/ou hiperfagia (Beales et al., 2009).

D'Angelo et al. (2010) sugerem que o segmento 1p36.33-36.32, na sua parte distal de 2-3 Mb , seria a região crítica para a manifestação da obesidade e hiperfagia.

\section{Deleção terminal em 2q37}

A síndrome de deleção de 2q37, também conhecida como osteodistrofia hereditária de Albright-like ou síndrome de braquidactilia e deficiência intelectual (BDMR), é outra síndrome de deleção terminal com mais de 100 pacientes já descritos (Leroy et al., 2013). Possui uma variabilidade fenotípica significativa, sendo suas principais características o atraso no desenvolvimento, problemas de comportamento, transtorno do espectro do autismo, defeitos cardíacos, obesidade e braquidactilia do tipo E (braquimetafalangia), além de baixa estatura, deficiência intelectual, hipotonia e fácies característica (Falk \& Casas, 2007; Morris et al., 2012).

Deleções ou mutações em heterozigose que envolvem o gene HDAC4 são descritas como a causa para o fenótipo da síndrome. HDAC4 regula fatores que são necessários para o desenvolvimento e regulação muscular, cardíaco e neurológico, sendo crítico para esqueletogênese e condrogênese adequadas, bem como a sobrevivência neuronal (Williams et al., 2010; Morris et al., 2012). 


\section{Deleção em 6q16.2 e haploinsuficiência do gene SIM1}

A perda do gene SIM1, localizado em 6q16.2, tem sido associada com hiperfagia na obesidade sindrômica. Em humanos, a deleção ou quebra da região SIM1 resulta em um fenótipo Prader-Willi-like ou uma forma de obesidade de início precoce associada com excesso de ingestão de alimentos, similar a hiperfagia vista em camundongos (Bell et al., 2005). O gene SIM1 desempenha um papel fundamental na diferenciação neuronal dentro do núcleo paraventricular do hipotálamo, região crítica na regulação da ingestão de alimentos (Bonnefond et al., 2013). Estes autores estudaram o envolvimento do gene SIM1 com o desenvolvimento da obesidade em 44 crianças com características de síndrome de Prader-Willi-like, 198 crianças com obesidade grave de início precoce, 568 adultos com obesidade mórbida e 383 controles, encontrando três mutações que mostraram fortes efeitos de perda de função (p.T46R, p.H323Y e p.T714A) e foram associadas com alto risco para a obesidade severa.

Holder et al. (2000) estudaram uma menina com obesidade de início precoce que possuia uma translocação cromossômica de novo entre os cromossomos 1p22.1 e 6q16.2, na qual o gene SIM1 foi rompido. Além disso, citam dois outros estudos de pacientes com fenótipo complexo, incluindo a obesidade de início precoce e pequenas deleções intersticiais que se sobrepõem à região de sua paciente.

Em um estudo com indivíduos apresentando fenótipo Prader-Willi-like, Varela et al. (2006) encontraram uma deleção de origem paterna do segmento 6q15-q21 em uma paciente, o que sugere que a obesidade de início precoce e a hiperfagia são determinadas pela haploinsuficiência do gene SIM1, enquanto 
a hipotonia, o atraso no desenvolvimento, dismorfismos faciais e extremidades pequenas são causados pela deleção de outros genes localizados no segmento cromossômico 6q15-q21. Vignoli et al. (2013) realizaram uma revisão da literatura com 25 pacientes apresentando deleção entre os segmentos $6 q 15$ e $6 q 23$. Identificaram entre as características comuns da síndrome a ocorrência de deficiência intelectual - variando de grave (16\% dos casos), moderada (24\%) a leve (20\%) e em $40 \%$ o grau de deficiência intelectual não foi especificado; problemas de comportamento (36\%), principalmente transtorno do espectro do autismo e déficit de atenção com hiperatividade e agressividade; 44\% com fenótipo PWS-like (que inclui obesidade, hipotonia e mãos e pés pequenos). Uma grande variabilidade foi observada entre os dismorfismos descritos, sendo os mais recorrentes: hipertelorismo (36\%), olhos amendoados (16\%), fissuras palpebrais oblíquas (28\%), ponte nasal larga (24\%), nariz bulboso $(20 \%)$, orelhas dismórficas (80\%), palato ogival (28\%), microrretrognatia (32\%) e mãos curtas ou dismórficas/dedos afilados nas pontas (48\%).

\section{Deleção terminal em 9q34.3}

Beales et al. (2009) apresentaram um estudo no qual duas crianças com obesidade e hiperfagia, deficiência intelectual, atraso no desenvolvimento, hipotonia, além de outras características dismórficas, tinham uma deleção terminal na região cromossômica 9q34.3. Esta região contém cerca de 20 genes. Em outro estudo com 13 pacientes possuindo essa mesma deleção, apenas dois apresentavam obesidade, apesar de que três morreram recémnascidos devido a problemas cardíacos congênitos (Goldstone et al, 2008). 
Atualmente esta síndrome é denominada síndrome de Kleefstra, em que já foram descritos mais de 100 pacientes com deleções submicroscópicas na região 9q34.3 ou com mutações intragênicas em EHMT1, causando a haploinsuficiência deste gene e consequentemente seu fenótipo. É caracterizada por atraso no desenvolvimento e deficiência intelectual de moderados a severos, hipotonia e características faciais distintas, compreendendo braquicefalia, microcefalia, sinofre, formato incomum das sobrancelhas, hipoplasia da face média, lábio inferior evertido, língua protrusa e prognatismo. As características clínicas adicionais incluem defeitos cardíacos e urogenitais congênitos, epilepsia, distúrbios comportamentais e psiquiátricos e sobrepeso (Willemsen et al., 2012).

\section{Síndrome de WAGR}

A síndrome de WAGR (tumor de Wilms, aniridia, anomalias genitourinárias, deficiência intelectual) é causada por deleções intersticiais da região 11 p13 devido à haploinsuficiência de genes nesta região, incluindo WT1 e PAX6. O gene WT1 é responsável pelo desenvolvimento do tumor de Wilms e nefropatias enquanto que PAX6 pela aniridia. Desta maneira, é reconhecida como uma síndrome de genes contíguos (Yamamoto et al., 2014).

Deleções maiores, com pontos de quebra centroméricos e teloméricos atípicos que abrangem a região $11 \mathrm{p} 14$, têm sido descritas em pacientes com fenótipo WAGR em associação com deficiência intelectual e obesidade (Shinawi et al., 2011). Este subgrupo que inclui obesidade é denominado WAGRO e tem sido associado com haploinsuficiência para o gene BDNF. O gene $B D N F$, presente na região $11 \mathrm{p} 14.1$, tem um papel fundamental na 
diferenciação de células, sobrevivência neuronal, migração, arborização dendrítica, sinaptogênese e desenvolvimento da medula espinhal (Shinawi et al., 2011). Rodríguez-López et al. (2013) afirmam que a região crítica para a obesidade infantil na síndrome de WAGR está localizada dentro de uma região de $80 \mathrm{~kb}$ do exon 1 de BDNF. Han et al. (2008) descreveram pacientes com haploinsuficiência de BDNF que apresentaram o IMC significativamente mais elevado durante a infância em comparação com controles, com uma prevalência de $100 \%$ de obesidade infantil.

\section{Síndrome de Smith-Magenis}

A síndrome de Smith-Magenis tem uma prevalência estimada de 1;15.000 - 25.000 nascimentos. Suas principais características são deficiência intelectual, distúrbios do sono (atribuído a um ritmo circadiano invertido), comportamento auto-agressivo, anomalias craniofaciais, neurológicas, baixa estatura e obesidade. Muitas das características pleiotrópicas da síndrome resultam da haploinsuficiência do gene RAl1 presente na região cromossômica 17p11.2. Trata-se de uma região rica em low copy repeats (LCRs) em que mais de $75 \%$ dos pacientes apresentam deleções de cerca de 3,7Mb, aproximadamente $16 \%$ apresentam deleções atípicas de $\sim 5 \mathrm{Mb}$ e aproximadamente $10 \%$ têm mutações pontuais em RAl1 (Elsea \& Williams, 2011). A duplicação recíproca desta região resulta na síndrome de PotockiLupski, com apresentação clínica variável que inclui deficiência intelectual, atraso de desenvolvimento, problemas de comportamento, características autistas, hipotonia, má alimentação e alterações cardiovasculares (Magoulas et al., 2014). 
Burns et al. (2010) estudaram o papel de RAl1 na obesidade, através da haploinsuficiência de Rai1 em camundongos. Os animais Rai1 ${ }^{\text {+/- }}$ apresentaram fenótipo obeso e hiperfágico. Também verificaram que RA/1 regula diretamente a expressão do $B D N F$, onde Bdnf é downregulated no hipotálamo dos camundongos Rai $1^{+/}$. Além disso, observaram que em pacientes com a síndrome de Smith-Magenis a obesidade de início precoce está presente em mais de $50 \%$ dos indivíduos a partir de 9 anos de idade (percentil igual ou superior a 85) e a obesidade truncal é mais comumente constatada.

\section{Síndrome de Bardet-Bield}

A síndrome de Bardet-Bield (BBS) tem uma freqüência estimada em 1:100.000 nascimentos e suas principais características são: distrofia retiniana, polidactilia, dificuldades de aprendizado, hipogonadismo, problemas renais e obesidade (Bell et al., 2005). O fenótipo dessa síndrome é heterogêneo, provavelmente devido a mutações em diversos loci genéticos, sendo os já mapeados: BBS1 em 11q13, BBS2 em 16q21, BBS3 em 3p13, BBS4 em 15q22.3, BBS5 em 2q31, BBS6 em 20p12, BBS7 em 4q27, BBS8 em 14q32.11, BBS9 em 7p14, BBS10 em 12q21.2, BBS11 em 9q33.1, BBS12 em 4q27, BBS13 em 17q23, BBS14 em 12q21.3, BBS15 em 2p15, BBS16 em 1q43, BBS17 em 3p21.31 e BBS18 em 10q25.2 (Forsythe \& Beales, 2013; Scheidecker et al., 2014).

A herança desta síndrome é considerada como autossômica recessiva, entretanto, a ocorrência de herança trialélica vem sendo sugerida em algumas famílias. Mutch et al., (2006) exemplificam que certas formas da BBS estão relacionadas com mutações recessivas em um dos loci associadas com outra 
mutação em um segundo locus, levantando também a hipótese de modelo de transmissão trialélica.

Além da BBS, outras síndromes, como a síndrome de Alström e a síndrome de Carpenter, têm a patogênese da obesidade ligada a disfunções dos cílios, organelas presentes em quase todas as células eucariontes. A fisiopatologia na BBS não está totalmente clara, mas há evidências que sugerem que defeitos dos cílios no transporte de vesículas podem levar ao fenótipo da doença, incluindo a hiperfagia e a obesidade (Kousta et al., 2009).

Mutações homólogas a BBS7 e BBS8 em Caenorhabditis elegans produzem defeitos na função ciliar, e mutações no BBS5 em Chlamydomonas levam a uma perda de flagelos. Todos os genes bbs conhecidos em $C$. elegans são expressos exclusivamente em células com cílios e em camundongos mutantes Bbs há perturbação ciliar grave com defeitos no olfato, defeitos do tubo neural e interrupção de feixes ciliares da cóclea (Barness et al., 2007).

Outras síndromes relacionadas ao fenótipo de obesidade estão brevemente descritas na Tabela 2.

\section{Hibridação Genômica Comparativa baseada em arrays}

A técnica de Hibridação Genômica Comparativa baseada em arrays (aCGH) é o método mais poderoso utilizado para detectar e localizar perdas e ganhos de material genético atualmente. (Mantripragada et al., 2004). Ele permite mapear todo o genoma de uma só vez com uma alta resolução e revelar alterações submicroscópicas do número de cópias do DNA que não são 
possíveis de avaliar por outras técnicas como o estudo do cariótipo tradicional (Vissers et al., 2003).

Inicialmente, seu uso principal foi na pesquisa de câncer, mas a aplicação no estudo de doenças genéticas congênitas tornou-se importante. Mantripragada et al. (2004) citam estudos que identificaram deleções em pacientes com síndrome de DiGeorge, além da detecção de deleções terminais e intersticiais, cromossomos derivados e rearranjos complexos em pacientes com deficiência intelectual.

A técnica de aCGH é baseada na hibridação de DNA teste e DNA referência em uma placa contendo sondas relacionadas às regiões do genoma. A resolução do método é determinada pela distância genômica entre as sondas e o tamanho dos fragmentos de DNA clonados. O DNA teste (DNA genômico que se pretende estudar) e o DNA referência (amostra controle) são marcados com fluorocromos verde e vermelho, respectivamente, e hibridados no array na presença de DNA Cot1, que bloqueia as sequências repetitivas. Depois da hibridação os sinais fluorescentes são capturados e sua intensidade quantificada. Regiões com intensidades fluorescentes iguais de DNA teste e referência resultam na cor amarela. As regiões deletadas são detectadas em vermelho e as regiões duplicadas aparecem em verde.

Slater et al. (2005) abordaram em seu estudo as vantagens do array em relação à análise citogenética, como a utilização de uma pequena quantidade de DNA, além de não ser necessária a produção de cultura celular que é demorada e algumas vezes problemática. A resolução é superior, permitindo uma análise mais refinada, determinando os pontos de quebra de forma mais precisa, além de identificar pequenas duplicações e deleções, inclusive em 
translocações aparentemente equilibradas. O array GeneChip Mapping 100K que utilizaram no trabalho, além de gerar dados do número de cópias como em outros aCGH, também ofereceu dados de genotipagem, possibilitando a detecção de alterações cromossômicas de cópias neutras, onde não há mudança no número de cópias, tais como dissomia uniparental (UPD). Gijsbers et al. (2009) também relatam que os arrays que pesquisam polimorfismos de nucleotídeo único (SNP) são utilizados na genotipagem e identificam variações do número de cópias (CNV) submicroscópicas, assim como baixos níveis de mosaicismos cromossômicos e UPDs. Em aproximadamente 25\% dos pacientes com deficiência intelectual/anomalias congênitas múltiplas, CNVs são detectados por aCGH e SNP array. Para Mantripragada et al. (2004), tanto pequenas duplicações e deleções quanto determinados SNPs podem ser importantes na detecção de fatores de predisposição a doenças.

Da mesma forma, De Vries et al. (2005) demonstram que a resolução do array e a cobertura de todo o genoma permitem uma maior detecção de alterações do número de cópias comparado aos resultados da análise cromossômica e da análise quantitativa das regiões subteloméricas com o uso de MLPA (Multiplex Ligation-dependent Probe Amplification), pois as alterações encontradas em seu estudo eram intersticiais e 7 de 10 anormalidades eram menores que $4 \mathrm{Mb}$.

Porém, Slater et al. (2005) e Gijsbers et al. (2009) descreveram uma desvantagem no uso do array em relação ao cariótipo tradicional que é a incapacidade de detectar rearranjos equilibrados, tais como translocações recíprocas e inversões. Cerca de $6 \%$ dos casos diagnosticados no pré-natal que apresentaram esses rearranjos estão associados a fenótipos anormais. 
Provavelmente, os pontos de quebra dos rearranjos interromperam um gene ou pequenas deleções ou duplicações além da resolução utilizada estão presentes. Dependendo da resolução do SNP array, sua análise pode detectar essas pequenas anomalias, mas o rompimento dos genes permanecerá desconhecido. A impossibilidade de detectar os rearranjos cromossômicos equilibrados é resultado do método de preparação, que inclui a fragmentação do genoma antes da hibridação aos BAC, PAC ou oligonucleotídeos do array, de forma que a informação linear não é preservada.

A população humana mostra extenso polimorfismo no número de cópias dos segmentos cromossômicos, algo conhecido como variação do número de cópias (CNV). Uma alta proporção do genoma, estimada em até $12 \%$ está sujeita a essa variação. Porém, a maior parte das variações é desvantajosa, e a mudança no número de cópias em algum gene específico pode levar a um grupo de condições patológicas conhecidas como doenças genômicas (Hastings et al., 2009).

Kearney et al. (2011) publicaram diretrizes para a interpretação e relato de variações do número de cópias. Os fatores que podem ser utilizados para auxiliar a interpretação das CNVs são: o tamanho do segmento, a posição (intersticial, centromérica, regiões de repetição), o número de cópias, o conteúdo gênico da CNV, a origem da CNV (de novo ou herdada) e a frequência na população em geral. Uma vez que o tamanho de uma CNV está associado com o número de genes afetados, a probabilidade de patogenicidade aumenta com o tamanho da CNV (Hehir-Kwa et al., 2013; Vulto-van Silfhout et al., 2013). 
Mudanças na quantidade de cópias de um ou mais genes são causas comuns de deficiência intelectual (Gijsbers et al., 2009), sendo que as regiões subteloméricas são conhecidas por serem afetadas por rearranjos submicroscópicos em aproximadamente 5\% dos pacientes com malformações e deficiência intelectual (de Vries et al., 2005).

De Vries et al. (2005) relatam o caso de um paciente com a deleção do segmento envolvido com a síndrome de DiGeorge e VCFS (síndrome velocardiofacial) que apresentava deficiência intelectual leve, baixa estatura e algumas características faciais sugestivas, mas sem as características de diagnóstico da VCFS, como anomalias cardíacas, fenda palatina, dedos longos e finos, hipocalcemia ou hipoplasia tímica, o que demonstra que o array $\mathrm{CGH}$ também auxilia no diagnóstico de fenótipos atípicos de síndromes comuns de microdeleções.

Muitas síndromes têm sido descritas como resultado de alterações do número de cópias que ocorrem no genoma, sendo identificadas após o avanço de tecnologias que detectam CNVs, como o array-CGH. A seguir, algumas dessas síndromes, em que a obesidade está presente como uma de suas características, são descritas. 


\section{Deleção em 1p21.3}

A síndrome de microdeleção em 1p21.3 é uma anomalia extremamente rara, com menos de 10 casos relatados até o momento, de ocorrência principalmente de novo que envolve o gene DPYD e o miRNA MIR137. É caracterizada por um atraso de linguagem grave, deficiência intelectual leve a moderada, transtorno do espectro do autismo, obesidade e características faciais dismórficas menores, como orelhas grandes, olhos profundos, ponte nasal larga e lábio inferior espesso (Willemsen et al., 2011; Carter et al., 2011).

\section{Deleção em 2p25.3}

A deleção da região de terminal do braço curto do cromossomo 2 já foi descrita na literatura em cerca de 13 pacientes, muitas vezes associada com um fenótipo de Prader-Willi-like (Doco-Fenzy et al., 2014). Estes autores descreveram 5 pacientes com deleção em 2p25 apresentando obesidade de início precoce, hiperfagia, deficiência intelectual e alterações comportamentais. A análise dos genes contidos na região deletada levou-os a especular que os genes ACP1, TMEM18, e/ou MYT1L podem estar envolvidos na obesidade de início precoce. Além disso, a deficiência intelectual e problemas de comportamento podem ser explicados pela perda de heterozigose dos genes SNTG2 e MYT1L.

Com o uso de microarrays, Stevens et al. (2011) identificaram deleções em 2p25.3, com tamanhos variando de 0.37 a $3.13 \mathrm{Mb}$, em três irmãos adultos e três pacientes não relacionados, todos apresentando deficiência intelectual, obesidade ou excesso de peso, sem características faciais dismórficas evidentes. Ao combinarem os dados encontrados com outros três pacientes da 
literatura definiram a região mínima de sobreposição que continha o gene MYT1L. Porém, não encontraram evidências na literatura de uma associação direta entre haploinsuficiência de MYT1L e excesso de peso. Já o gene TMEM18, previamente associado à obesidade, estava deletado em quatro dos pacientes.

Rio et al. (2013) relataram duas irmãs gêmeas monozigótigas com genótipos discordantes, resultado de uma alteração cromossômica na região 2p25.3, provavelmente devido a uma recombinação mitótica não-alélica que ocorreu durante as divisões do blastômero de um zigoto normal, levando a um fenótipo também discordante. Uma gêmea apresentava atraso no desenvolvimento global, excesso de peso e hiperatividade devido a deleção em 2p25.3 enquanto que a outra gêmea apresentava o transtorno do espectro autista devido ao mosaicismo, onde um terço das células mostrou uma deleção em 2p25.3, um terço das células uma duplicação em 2p25.3 e um terço das células eram normais. A gêmea com apenas a deleção exibiu um fenótipo compatível com o descrito na literatura para outros portadores desta deleção em que sua CNV, abrangendo os genes MYT1L, SNTG2 e TMEM18, sugere ser uma ligação causal entre a alteração genômica e o fenótipo observado.

\footnotetext{
Translocação não equilibrada entre os cromossomos 8 e 12 $\operatorname{der}(8) t(8 ; 12)(p 23.1 ; p 13.31)$

Goldlust et al. (2013) descreveram 7 pacientes compartilhando o mesmo rearranjo genômico, uma translocação não equilibrada entre os cromossomos 8 e 12, resultando numa perda de 7,0Mb no braço curto do cromossomo 8 e um ganho de 8,5Mb no braço curto do cromossomo 12 e fenótipo de deficiência
} 
intelectual, macrocefalia, eczema, convulsões e obesidade. Há 23 genes dentro da deleção em 8p e 107 genes dentro da duplicação em 12p, com destaque para o gene GNB3 no cromossomo 12, previamente associado com obesidade.

O gene GNB3 codifica a subunidade GB3 (proteína G $\beta 3$ ) que é expressa em todos os tecidos, representando um componente chave na transdução de sinal intracelular. Localiza-se no cromossomo $12 \mathrm{p} 13$ e compreende 11 éxons e 10 íntrons. O polimorfismo C825T no éxon 10 não afeta a sequência de aminoácidos, mas está associado com a ocorrência de uma proteína diferente, denominada G $\beta 3$ s, devido a um splicing variante, que resulta em um ganho dominante de função, ou seja, um aumento na transdução de sinal em células e tecidos humanos. O polimorfismo C825T do gene GNB3 tem sido associado com vários fenótipos, incluindo a hipertensão, arteriosclerose, obesidade, resistência à insulina, depressão e respostas imunes (Kenkle et al., 2011).

Ou et al. (2011) forneceram evidência molecular que apoia que NAHR entre LCR intercromossômicas seja um potencial mecanismo para translocações recíprocas recorrentes. Análises do banco de dados de seus pacientes estudados por array retornou dois casos com $\operatorname{der}(8) \mathrm{t}(8 ; 12)(\mathrm{p} 23.1 ; \mathrm{p} 13.31)$. Análise bioinformática dos pontos de quebra nas regiões da $\mathrm{t}(8 ; 12)$ revelou um cluster de LCR de $\sim 579 \mathrm{~kb}$ (posição genômica 7,52 - 8,10Mb) no cromossomo 8p23.1 e um cluster de LCR de $\sim 287 \mathrm{~kb}$ no cromossomo 12p13.31 (posição genômica 8,31 - 8,60Mb), que compartilham $285 \mathrm{~kb}$ de homologia significativa (sequência de identidade do DNA > 94\%). 


\section{Locus 16p11.2}

O braço curto do cromossomo 16 é rico em duplicações segmentares (segmental duplications) (trechos maiores que $1 \mathrm{~kb}$ com uma alta identidade com outras sequências). Os mais conhecidos distúrbios genômicos recorrentes resultam da recombinação homóloga não-alélica (NAHR) ou crossing-over desigual entre esses segmentos grandes e altamente idênticos (> $10 \mathrm{~kb}$ ) (Girirajan et al., 2010). Vários desequilíbrios genômicos (microdeleções ou microduplicações) já foram caracterizados tendo pontos de quebra mapeados dentro de duplicações segmentares do cromossomo 16, associados ao autismo, esquizofrenia, deficiência intelectual, anomalias congênitas e obesidade (Itsara et al., 2009; Girirajan et al., 2010; Bachmann-Gagescu et al., 2010; Sahoo et al., 2011).

Bochukova et al. (2010) estudaram 300 pacientes com obesidade severa de início precoce, sendo que 143 tinham também atraso no desenvolvimento. Foram identificados três pacientes com a deleção no cromossomo 16p11.2, sendo que em dois destes pacientes (que possuiam atraso leve de desenvolvimento) a deleção estendia-se por uma região de 593kb anteriormente associada a autismo e deficiência intelectual. Em outra amostra de 1.062 pacientes com apenas obesidade grave detectaram a deleção de 16p11.2 em mais dois pacientes. Assim, os autores relataram 5 pacientes portando a deleção em 16p11.2 com uma região mínima de sobreposição de 220kb (28.73-28.95 Mb, hg 18) que inclui o gene SH2B1, conhecido por estar envolvido na sinalização da insulina e leptina.

Walters et al. (2010) relataram uma forma altamente penetrante da obesidade, inicialmente observada em 31 indivíduos que eram heterozigotos 
para deleções de aproximadamente 600kb em 16p11.2 (29.5-30.1 Mb) e também apresentavam déficits cognitivos. Os autores fizeram um levantamento a partir de GWAS realizados em 16.053 indivíduos de oito coortes europeias identificando dezenove deleções semelhantes ao seu achado. Essas deleções estavam ausentes dos controles não obesos e representavam $0,7 \%$ dos casos de obesidade mórbida.

A duplicação recíproca desta região de $600 \mathrm{~kb}$ foi associada a um fenótipo espelho ao IMC extremo. Jacquemont et al. (2011) detectou 138 portadores da duplicação que mostram uma redução significativa no peso e IMC pós-natal $\left(\mathrm{IMC}<18,5 \mathrm{~kg} / \mathrm{m}^{2}\right)$, tanto em indivíduos com atraso no desenvolvimento e deficiência intelectual como em indivíduos sem essas características. Também detectou uma associação entre a deleção e a duplicação com aumento e redução do perímetro cefálico $(26,7 \%$ apresentando microcefalia), respectivamente.

Al-Kateb et al., (2014) estudaram 10 pacientes com rearranjos em 16p11.2, sugerindo que casos com rearranjos nesta região têm uma maior incidência de escoliose e anomalias vertebrais. Dois destes pacientes portavam uma deleção na região e tinham a obesidade como uma de suas características.

\section{Deleção em 17q24.2}

Vergult et al. (2012) descreveram 4 pacientes com deleções em 17q24.2 e fenótipo de atraso no desenvolvimento, atraso na fala, problemas de alimentação na infância, obesidade truncal e fácies semelhante. Eles apresentavam a menor região de sobreposição das deleções de 713 kb de 
tamanho que contêm um microRNA e cinco genes: PRKCA, HELZ e um conjunto de três genes CACNG que codificam a subunidade gama de um canal de cálcio dependente de voltagem.

Já Lestner et al. (2012) e Bartnik et al. (2014) descrevem pacientes com deleções que se sobrepõem parcialmente às descritas acima, apresentando algumas características clínicas comuns como atraso no desenvolvimento, deficiência intelectual, problemas de alimentação e características faciais dismórficas, como fronte alta e larga, hipertelorismo e epicanto, porém sem o fenótipo de obesidade.

PRKCA codifica uma proteína quinase $\mathrm{C}$ alfa, que tem um papel importante em muitos processos celulares diferentes. Uma análise de ligação do genoma ao IMC apontou PRKCA como um locus pleiotrópico a ser associado com o IMC e asma (Murphy et al., 2009). A deleção de PRKCA pode contribuir para a obesidade truncal observada (Vergult et al., 2012). 
Tabela 2 - Algumas síndromes genéticas que apresentam obesidade como característica clínica

\begin{tabular}{|c|c|c|c|}
\hline Síndrome & $\begin{array}{l}\text { Localização } \\
\text { cromossômica }\end{array}$ & Gene & Principais caracteristicas \\
\hline $\begin{array}{l}\text { Osteodistrofia Hereditária } \\
\text { de Albright (AHO) e } \\
\text { Pseudohipoparatireoidis- } \\
\text { mo tipo la (PHP1A) }\end{array}$ & $20 q 13$ & GNAS1 & $\begin{array}{l}\text { AHO (pseudo-pseudohipoparatireoidismo): } \\
\text { baixa estatura, braquidactilia, obesidade, } \\
\text { deformidades crânio-faciais, membros } \\
\text { curtos ou ossos metacarpianos curtos, } \\
\text { calcinose subcutânea; em alguns casos } \\
\text { anomalias mentais e do desenvolvimento. } \\
\text { PHP1A: fenótipo de AHO com a presença } \\
\text { também de resistência multihormonal. } \\
\text { Relacionadas ao imprinting do gene, sendo } \\
\text { que o alelo materno mutado leva à PHP1A, } \\
\text { enquanto que o alelo paterno mutado leva } \\
\text { a AHO }\end{array}$ \\
\hline S. Alström & $2 p 13$ & ALMS1 & $\begin{array}{l}\text { Deficiência neurossensorial, obesidade na } \\
\text { infância, resistência à insulina, } \\
\text { hiperisulinemia levando à diabetes tipo } 2 \text {, } \\
\text { hipogonadismo em homens, baixa estatura }\end{array}$ \\
\hline S. Carpenter & $6 \mathrm{p} 11$ & $R A B 23$ & $\begin{array}{l}\text { Oxicefalia, craniossinostose, braquidactilia } \\
\text { e sindactilia nas mãos, polidactilia pré-axial } \\
\text { nos pés, anomalias dentais. Obesidade } \\
\text { presente em pacientes mais velhos }\end{array}$ \\
\hline S. Cohen & $8 q 22.2$ & $\mathrm{COH} 1$ & $\begin{array}{c}\text { Deficiência intelectual, microcefalia, fácies } \\
\text { típica, obesidade, baixa estatura, hipotonia, } \\
\text { distrofia retiniana progressiva }\end{array}$ \\
\hline $\begin{array}{l}\text { S. Börjeson-Forssman- } \\
\text { Lehmann }\end{array}$ & Xq26.3 & PHF6 & $\begin{array}{c}\text { Deficiência intelectual, obesidade, } \\
\text { ginecomastia, hipogonadismo, orelhas } \\
\text { grandes }\end{array}$ \\
\hline S. Wilson-Turner & Xq21.2-q22 & WTS & $\begin{array}{l}\text { Deficiência intelectual, obesidade, } \\
\text { ginecomastia, dificuldades na fala, } \\
\text { instabilidade emocional, dedos afilados, } \\
\text { pés pequenos }\end{array}$ \\
\hline S. Ahmad & Xp11.3-q23 & - & $\begin{array}{l}\text { Deficiência intelectual, obesidade, } \\
\text { hipogonadismo, dedos afilados }\end{array}$ \\
\hline MEHMO & Xp21.1-p22.13 & - & $\begin{array}{c}\text { Deficiência intelectual, epilepsia, } \\
\text { hipogonadismo, microcefalia, obesidade }\end{array}$ \\
\hline
\end{tabular}

Baseado em Beales et al, 2009 e Kousta et al, 2009 
Objetivos 


\section{II-Objetivos}

O presente trabalho tem como principal objetivo investigar pacientes com obesidade e/ou hiperfagia associada a atraso do desenvolvimento neuropsicomotor, dificuldades de aprendizagem, distúrbios de comportamento e outras características clínicas visando à identificação de alterações no genoma relacionadas à obesidade e hiperfagia.

\section{Objetivos específicos}

Estudar com plataformas de SNP array ("The GeneChip ${ }^{\circledR}$ Mapping 500K Set", da Affymetrix) e/ou de array CGH (CytoSure ISCA, da Oxford Gene Technology - OGT) pacientes com obesidade sindrômica que foram anteriormente estudados por meio de testes de MLPA que investigam as regiões subteloméricas de todos os cromossomos e várias regiões genômicas nas quais as deleções e duplicações estão associadas a síndromes conhecidas e apresentaram resultados normais.

Investigar in silico as funções de genes presentes nas regiões alteradas a fim de correlacioná-los a obesidade e hiperfagia.

Correlacionar as diferentes alterações cromossômicas às características fenotípicas e comportamentais dos pacientes.

Proporcionar o diagnóstico e prognóstico dos pacientes e Aconselhamento Genético aos pais e familiares. 
Casuística e Metodologia 


\section{III - Casuística e Metodologia}

\section{Casuística}

Os pacientes com suspeita de diagnóstico clínico de PWS são encaminhados ao nosso Serviço por médicos do Hospital das Clínicas da FMUSP, por médicos da UNIFESP-EPM e de outras instituições para testes genéticos.

A amostra foi composta por 31 pacientes com atraso do DNPM e/ou dificuldade de aprendizado, distúrbios de comportamento, obesidade e/ou hiperfagia que apresentaram resultado negativo para o teste de metilação para PWS/AS (Dra. Mônica Castro Varela). Alguns pacientes também tiveram seu DNA analisado por testes de MLPA (Multiplex Ligation-dependent Probe Amplification), que estudam as regiões subteloméricas dos cromossomos (kits P036 e P070) e regiões relacionadas a deficiência intelectual (kit P064) (MSc. Claudia Irene Emílio de Castro), além de um kit sintético elaborado em nosso laboratório pela Pós-Doutoranda Carla S. D’Angelo contendo regiões já descritas na literatura envolvidas com obesidade.

Para cada paciente foi preenchida uma ficha de anamnese genética contendo dados gestacionais, familiais e fenotípicos. As características comportamentais fornecidas pelos genitores, assim como as observadas durante a consulta, foram anotadas. No momento da consulta, o(s) responsável(is) legal(is) pelo paciente assinou(aram) um termo de consentimento livre e esclarecido autorizando a realização dos exames moleculares e o armazenamento do DNA. O sangue dos genitores, quando possível, também foi colhido para extração de DNA e, se necessário, para a realização do cariótipo. O projeto de Pesquisa ao qual se insere este trabalho 
foi aprovado pelo Comitê de Ética em Pesquisa do Instituto de Biociências da Universidade de São Paulo, sob o Protocolo de número 021/2004.

\section{Metodologia}

Nove pacientes selecionados tiveram seu DNA genômico extraído de linfócitos do sangue periférico para o estudo do genoma pela técnica de SNParray, com o uso do Kit "The GeneChip Mapping 500K Set" (Affymetrix), segundo protocolo fornecido pelo fabricante, para verificar a ocorrência de variações no número de cópias (CNVs) no material genético. A análise dos dados foi realizada através do The Affymetrix ${ }^{\circledR}$ Genotyping Console ${ }^{\mathrm{TM}}$ software (GTC) versão 4.0 .

Para se determinar quais CNVs encontradas são relevantes para o estudo, os seguintes parâmetros foram delimitados: CNVs com tamanho mínimo de $300 \mathrm{~kb}$, segmentos que possuem no mínimo 5 marcadores (número de SNPs usados para avaliar perda de heterozigosidade) e porcentagem menor que $50 \%$ de marcadores no segmento que se sobrepõem aos limites de conhecidas CNVs, presentes no banco de dados DGV Toronto.

Oito dos pacientes analisados com o SNP-array da Affymetrix foram analisados também pelo array-CGH CytoSure da OGT ISCA $8 \times 60 \mathrm{k}$ (colaboração da Dra Carla Rosenberg) para a confirmação dos resultados obtidos anteriormente.

Em seguida foram selecionados mais 22 pacientes para serem analisados pelo array-CGH CytoSure da OGT ISCA 4x180k. Este array é composto de aproximadamente 180.000 oligonucleotídeos de 60-mer a uma distância de cerca de $25 \mathrm{~kb}$ entre oligonucleotídeos, cobrindo todo o genoma. 
O protocolo utilizado foi o fornecido pelo fabricante e a análise feita no programa Agilent Genomic Workbench Lite Edition 6.5.0.18, considerando alterações maiores que $300 \mathrm{~kb}$, presentes em regiões com genes e/ou que rompessem algum gene.

Os pacientes que apresentaram alterações no genoma tiveram os genitores também estudados.

Nos pacientes nos quais foi observada alguma alteração genômica realizamos o cultivo do sangue em meio apropriado para estudo citogenético com a finalidade de investigar por bandamento GTG a ocorrência de alterações numéricas e estruturais, além da técnica de FISH (fluorescence in situ hybridization) ou da técnica de $\mathrm{PPCR}$ (quantitative polymerase chain reaction) para a validação do diagnóstico obtido através do array.

A investigação in silico de genes relacionados à obesidade e/ou hiperfagia e atraso do DNPM, dificuldade de aprendizado e/ou distúrbios de comportamento foi realizada através dos bancos de dados do Ensembl Genome Browser e University of California Santa Cruz Genome Bioinformatics (UCSC). A análise dos dados foi feita através de pesquisas a banco de dados de diversos sites como GeneCards, DECIPHER, ISCA, OMIM, entre outros, e artigos depositados no PubMed.

\section{Cultura de linfócitos de sangue periférico}

Os pacientes e seus genitores tiveram cerca de $5 \mathrm{~mL}$ de sangue coletado em tubo heparinizado. 
Ao meio de cultura RPMI Medium 1640 (Gibco) foi acrescentado 20\% de soro fetal bovino (Cultilab), $1,5 \%$ de fitohemaglutinina (Gibco) e $0,3 \%$ de Lglutamina (Sigma).

Em $10 \mathrm{~mL}$ de meio de cultura foram semeadas 10 gotas de sangue total e incubados em estufa a $37^{\circ} \mathrm{C}$ por 72 horas. Pouco antes do término das 72 horas foi acrescentado $10 \mu \mathrm{L}$ de brometo de etídio ao meio, permanecendo por 3 horas e 15 minutos na estufa. Após esse período, foi adicionado $200 \mu \mathrm{L}$ de colchicina, ficando mais 45 minutos na estufa.

Ao término do período, as amostras foram transferidas para tubos falcon e centrifugadas por 5 minutos a 1500rpm em temperatura ambiente. 0 sobrenadante foi desprezado e, em seguida, acrescentou-se solução hipotônica de cloreto de potássio $(\mathrm{KCl})$ até completar $8 \mathrm{~mL}$. O material foi bem homogeneizado e permaneceu em temperatura ambiente por 30 minutos, sendo ressuspendido algumas vezes.

Após os 30 minutos acrescentou-se $2 \mathrm{~mL}$ de fixador, preparado com 3 partes de metanol para 1 parte de ácido acético, novamente ressuspendido e centrifugado por 5 minutos a $1500 \mathrm{rpm}$. O sobrenadante foi descartado e agora acrescentado mais $5 \mathrm{~mL}$ de fixador, ressuspendido e centrifugado por 5 minutos a 1500rpm. Este último processo foi repetido mais duas vezes, totalizando três etapas de lavagem.

Após a última etapa de lavagem, adicionou-se $5 \mathrm{~mL}$ de Cytoclear (ProCell Reagents) por 5 minutos a temperatura ambiente, seguido de mais um ciclo de centrifugação e acréscimo de fixador de acordo com a quantidade de pellet formada. O Cytoclear é utilizado para remover o citoplasma que permaneceu após o processo de lavagem com fixador. 
Lâminas limpas mantidas em geladeira foram posicionadas sobre o banho-maria onde se pingou 3 gotas do material fixado para a análise.

\section{Análise cromossômica por bandamento GTG}

As lâminas foram envelhecidas por uma semana e também por 5 minutos em microondas. Então foram incubadas em 2XSSC (cloreto de sódio $0,3 \mathrm{M}$ e citrato trissódico $0,03 \mathrm{M}$ ) por 5 minutos a $65^{\circ} \mathrm{C}$ seguida de lavagem em água destilada e secas a temperatura ambiente. Em seguida, foram incubadas em solução de tripsina $0,025 \%$ em tampão fosfato Sorensen $\left(\mathrm{Na}_{2} \mathrm{HPO}_{4}\right.$ 0,03M e $\left.\mathrm{NaH}_{2} \mathrm{PO}_{4} 0,03 \mathrm{M}\right) \mathrm{pH} 6,8$ à $37^{\circ} \mathrm{C}$ por tempo variável de 45 a 60 segundos, lavadas em água destilada e álcool $80^{\circ}$ e coradas com solução Giemsa a $4 \%$ em tampão fosfato Sorensen por 10 minutos.

As lâminas foram analisadas em microscópio Axiophot Motorizado (Zeiss) e pelo menos 10 metáfases foram capturadas por câmera de vídeo e cariotipadas no programa lkaros (Metasystems).

\section{Análise citogenética molecular por FISH (fluorescence in situ hybridization)}

Em quatro pacientes foi realizado o estudo por fluorescence in situ hybridization (FISH), para confirmação do resultado obtido no array. As sondas específicas para as regiões alteradas foram pesquisadas no banco de dados do Ensembl Genome Browser, com a finalidade de se encontrar sondas presentes em BACs da biblioteca de 1Mb, mantida no laboratório da Profa. Dra. Angela M. V. Morgante e gentilmente cedidos para este trabalho. 
Os BACs de interesse foram inoculados em $2 \mathrm{~mL}$ de meio TB acrescido de $2 \mu \mathrm{L}$ de antibiótico cloranfenicol e deixados para crescer overnight em um shaker a $225-300 \mathrm{rpm}$ a $37^{\circ} \mathrm{C}$. O isolamento do DNA dos clones de BAC foi feito segundo protocolo fornecido por CHORI, com a substituição do último passo pela incubação em banho-maria a $60^{\circ} \mathrm{C}$ por 15 minutos.

As sondas foram marcadas pela reação de nick translation com biotina ou digoxigenina utilizando os kits Biotin-Nick Translation Mix e Dig-Nick

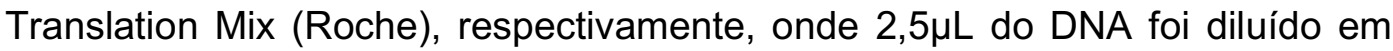
$1 \mu \mathrm{L}$ do Mix e $6,5 \mu \mathrm{L}$ de água Milli-Q e incubado por 4 horas a $15^{\circ} \mathrm{C}$.

Logo após foi realizada a etapa de precipitação onde foi acrescentado à mistura acima $7 \mu \mathrm{L}$ de COT-1 (Invitrogen), $1,7 \mu \mathrm{L}$ de acetato de sódio e $42,5 \mu \mathrm{L}$ de etanol $100 \%$ a $-20^{\circ} \mathrm{C}$ e deixado overnight no freezer a $-20^{\circ} \mathrm{C}$. O material foi centrifugado a $13.000 \mathrm{rpm}$ por 30 minutos a $4^{\circ} \mathrm{C}$, o sobrenadante descartado e o pellet lavado em $50 \mu \mathrm{L}$ de etanol $70 \%\left(-20^{\circ} \mathrm{C}\right)$, seguido de mais um ciclo de centrifugação por 10 minutos a mesma temperatura e rotação e o descarte do sobrenadante. As sondas foram ressuspendidas em $15 \mu \mathrm{L}$ de meio de hibridação e desnaturadas por 10 minutos a $100^{\circ} \mathrm{C}$.

As lâminas foram desnaturadas em solução de formamida $(70 \%$ de formamida, $10 \%$ de 20 XSSC e $20 \%$ de água Milli-Q) por 2 minutos a $73^{\circ} \mathrm{C}$. A sonda foi aplicada na lâmina e esta incubada em câmara úmida em estufa a $37^{\circ} \mathrm{C}$ overnight.

Após a incubação, as lâminas foram lavadas em 2 soluções de lavagem iguais (50\% de formamida, $10 \%$ de 20XSSC e $40 \%$ de água Milli-Q) por 3 minutos cada seguido de banho por 5 minutos em solução de $2 \mathrm{XSSC}$, a $37^{\circ} \mathrm{C}$, e um banho de PBT por 5 minutos a temperatura ambiente. 
O anticorpo utilizado foi avidina conjugada a FITC para a sonda marcada com biotina e para a sonda marcada com digoxigenina utilizou-se o anticorpo anti-digoxigenina conjugada com rodamina, ambos diluídos em 1:50 em PBT. Aplicou-se $20 \mu \mathrm{L}$ do anticorpo na lâmina, incubando-a em câmara úmida a $37^{\circ} \mathrm{C}$ por 45 minutos. A seguir, 3 banhos de PBT de 2 minutos a temperatura ambiente foram dados e as lâminas coradas com $15 \mu \mathrm{L}$ de DAPI (Sigma) mais Vectashield Mouting Médium (Vector Laboratories).

As lâminas foram analisadas em microscópio Axiophot Motorizado (Zeiss) e pelo menos 10 metáfases foram capturadas por câmera de vídeo com os filtros específicos para a detecção da fluorescência e analisadas no programa Isis (Metasystems).

\section{Quantitative polymerase chain reaction (qPCR)}

Para as alterações menores em que não seria possível utilizar as sondas da técnica de FISH, realizou-se o estudo com a técnica de quantitative polymerase chain reaction ( $\mathrm{PPCR}$ ), também conhecida por real-time PCR. Foram estudados 3 pacientes e seus genitores, sendo que de cada alteração genômica selecionou-se um gene de interesse para o desenho dos primers.

As amostras de DNA dos pacientes, genitores e controles (feminino e masculino) foram diluídas para uma concentração de $5 \mathrm{ng} / \mu \mathrm{L}$. Preparou-se o mix com $10 \mu \mathrm{L}$ de SYBR® Green PCR Master Mix (Applied Biosystems), 0,6 $\mu \mathrm{L}$ do Primer Foward a 10mM, 0,6 $\mu \mathrm{L}$ do Primer Reverse a $10 \mathrm{mM}$ e $4,8 \mu \mathrm{L}$ de água Milli-Q. Esse mix foi adicionado a $4 \mu \mathrm{L}$ de DNA das amostras. Os genes para controle endógeno utilizados foram GAPDH (no cromossomo 12) e HPRT (no cromossomo X) e os experimentos realizados em quadruplicata. 
A reação de PCR ocorreu no equipamento $A B I 7500$ Fast e foi constituída por 40 ciclos compostos por desnaturação a $95^{\circ} \mathrm{C}$ por 15 segundos e uma etapa de anelamento/extensão com 60 segundos a $60^{\circ} \mathrm{C}$.

O método utilizado para quantificação relativa é o da comparação do limiar da fase exponencial (Cycle Threshold - $\mathrm{C}_{T}$ ), que consiste na comparação dos valores $\mathrm{C}_{\mathrm{T}}$ da amostra com os valores $\mathrm{C}_{\mathrm{T}}$ do controle. Os valores de $\mathrm{C}_{\mathrm{T}}$ de ambos são normalizados aos de genes endógenos. Tal método é também conhecido por método $2^{-\Delta \Delta C T}$, onde $\Delta \Delta C_{T}=\Delta C_{\text {Tamostra }}-\Delta C_{\text {Tcontrole }}$. Nesta equação, $\Delta \mathrm{C}_{\mathrm{T}}$ amostra é o valor de $\mathrm{C}_{\mathrm{T}}$ da amostra normalizada ao gene endógeno e $\Delta \mathrm{C}_{\mathrm{T}}$ controle é o valor de $\mathrm{C}_{\mathrm{T}}$ para o controle normalizado ao gene endógeno (Schmittgen \& Livak, 2008; Ma et al., 2006). 


\section{Resultados e Discussão}




\section{IV - Resultados e Discussão}

Dos nove pacientes estudados com "The GeneChip Mapping 500K Set" (Affymetrix), apenas um apresentou uma alteração de ganho de cópia do material genético. E, ao serem analisados pelo array ISCA 8x60k da OGT, este paciente dentre os nove teve o resultado da duplicação intersticial no braço longo do cromossomo 17q11.2 de 540kb confirmado.

Em seguida, 22 pacientes foram estudados com o array-CGH CytoSure ISCA 4x180k da OGT. Sete pacientes apresentaram alterações de número de cópias do genoma, sendo 6 alterações patogênicas ou possivelmente patogênicas e uma provavelmente benigna.

Os capítulos a seguir referem-se aos pacientes nos quais alterações foram encontradas. Descrevemos os dados obtidos na anamnese, os resultados encontrados e a discussão dos achados. No Anexo 1 incluímos a descrição dos pacientes nos quais não foram observadas alterações. 


\section{Paciente 9}

G. F. O., sexo feminino, 6 anos e 7 meses. Pai com 38 e mãe com 35 anos, não-consanguíneos, não há histórico de aborto. Irmãos de 18 e 13 anos, saudáveis. Relato de casos na família: sobrinho da mãe tem hiperatividade. A paciente foi encaminhada ao nosso serviço com suspeita de obesidade sindrômica. A gestação durou 33 semanas, necessitou de medicações no $4^{\circ} \mathrm{e}$ $5^{\circ}$ mês para manter a gestação. Parto cesáreo devido à ausência de dilatação, peso ao nascimento $1820 \mathrm{~g}$, comprimento $44 \mathrm{~cm}$ e perímetro cefálico $31 \mathrm{~cm}$, boa sucção; apgar 9-10. Icterícia. Hipotonia neonatal. Ganhou peso rapidamente. Hiperfagia e obsessão por comida desde os 5 meses. Firmou a cabeça com 7 meses, sentou sem apoio após 1 ano e começou a andar com quase 2 anos e formular frases com mais de 6 anos. Tem atraso psicológico de 3 anos em relação à idade cronológica. Problemas de articulação da fala. Atraso no desenvolvimento global. Atraso DNPM.

Na ocasião da consulta apresentava estatura de 1,16 m (p25-p50), peso $33,5 \mathrm{~kg}(\mathrm{p}>97,5)$ e perímetro cefálico $50,5 \mathrm{~cm}$ (p50-p75). Braquicefalia, fronte alta e proeminente, implantação baixa de cabelos na fronte. Orelhas rotadas, lóbulo solto, hélices auriculares espessas. Sinofre, epicanto, olhos amendoados, estrabismo, olhos fundos. Nariz em sela. Lábio superior fino e inferior levemente fino, filtro curto. Queixo pontudo. Clinodactilia do $5^{\circ}$ dedo das mãos, pregas palmares normais. Cardiopatia congênita. Auto-abraço. Nunca teve transtorno de sono noturno. Hábito de cutucar feridas. Teimosia, acessos de violência, variações rápidas de humor, comportamento obsessivo/compulsivo. Medicado com ritalina devido à hiperatividade. 
No retorno para coleta de material para estudo citogenético (15/08/2011) a paciente apresentava estatura 1,22 m (p50-p75) e peso $37 \mathrm{~kg}(p>97,5)$. Realiza atividades sozinha como escovar os dentes e trocar de roupa. Frequenta escola especial.

Estudo do padrão de metilação da região PWS/AS e teste de MLPA com os kits P036-E1, P070-B1 e P064-B2 normais.

O emprego do GeneChip Mapping 500K (Affymetrix) mostrou uma duplicação intersticial no braço longo do cromossomo $17 q 11.2$ de 362kb entre os SNPs SNP_A-4256690 localizado em 29,147,164pb e SNP_A-1878539 localizado em 29,508,775pb, conforme o Ensembl Genome Browser (versão NCBI37/hg19).

Com a finalidade de validar a duplicação encontrada no array, realizouse o FISH utilizando a sonda RP11-229K15 para o cromossomo 17q11.2, observando-se marcações nos dois cromossomos 17 , sendo que em um dos cromossomos a marcação era mais intensa (Figura 3). O cariótipo apresentou resultado $46, \mathrm{XX}$.

O emprego do array CytoSure ISCA 8x60k (OGT) também detectou uma duplicação intersticial no braço longo do cromossomo $17 q 11.2$ de $540 \mathrm{~kb}$ entre 29,033,663pb e 29,598,392pb (hg19).

Os genitores foram estudados pelo array CytoSure ISCA 4x180k (OGT) verificando-se que a duplicação foi herdada do pai cuja coordenada genômica é $28,973,693-29,598,251 \mathrm{pb}$. A diferença entre os pontos de quebra presentes na microduplicação da paciente e do pai é provavelmente devido à resolução dos diferentes formatos de array utilizados (8x60k para a paciente e 4x180k para o pai) cuja distância genômica entre as sondas, menor no array 4x180k, 
pode resultar em valores de início e término da alteração divergentes, mas como pode ser visto na Figura 2, envolvem os mesmos genes.

A análise do genoma do paciente por array revelou uma duplicação de 9 genes no cromossomo 17. Esta região contém parcialmente o gene NF1 que, quando mutado, causa a neurofibromatose tipo 1 (NF1), de herança autossômica dominante. Aproximadamente $5 \%$ dos indivíduos com NF1 apresentam microdeleções envolvendo o gene NF1 e outros genes desta região, causando a síndrome de microdeleção do $N F 1$, onde o fenótipo é mais grave do que nos quadros com mutações intragênicas (Moles et al., 2012).

Dentre os genes duplicados destacamos $A D A P 2$, também conhecido como CENTA2, com uma ampla distribuição nos tecidos, sendo particularmente abundante no coração, tecido adiposo e músculo esquelético (Whitley et al., 2002). Os genes CENTA2 e JJAZ1 (este último fora da região duplicada da paciente) são significativamente expressos no coração e candidatos a serem responsáveis por anomalias cardiovasculares (Venturin et al., 2004); DPRXP4, um pseudogene membro da família de genes homeobox que se acredita estar envolvido com o início do desenvolvimento embrionário; e RNF135. Douglas et al. (2007) sugerem que o gene RNF135, presente na duplicação de nossa paciente, quando em haploinsuficiência contribui para um crescimento excessivo e dismorfismos faciais, além de dificuldades no aprendizado e outras anomalias congênitas. Os autores também identificaram mutações heterozigotas neste gene em 4 de 245 indivíduos com uma síndrome de crescimento excessivo caracterizada por aumento no peso e estatura pósnatal, macrocefalia, deficiências de aprendizado e características faciais dismórficas. 
17

A
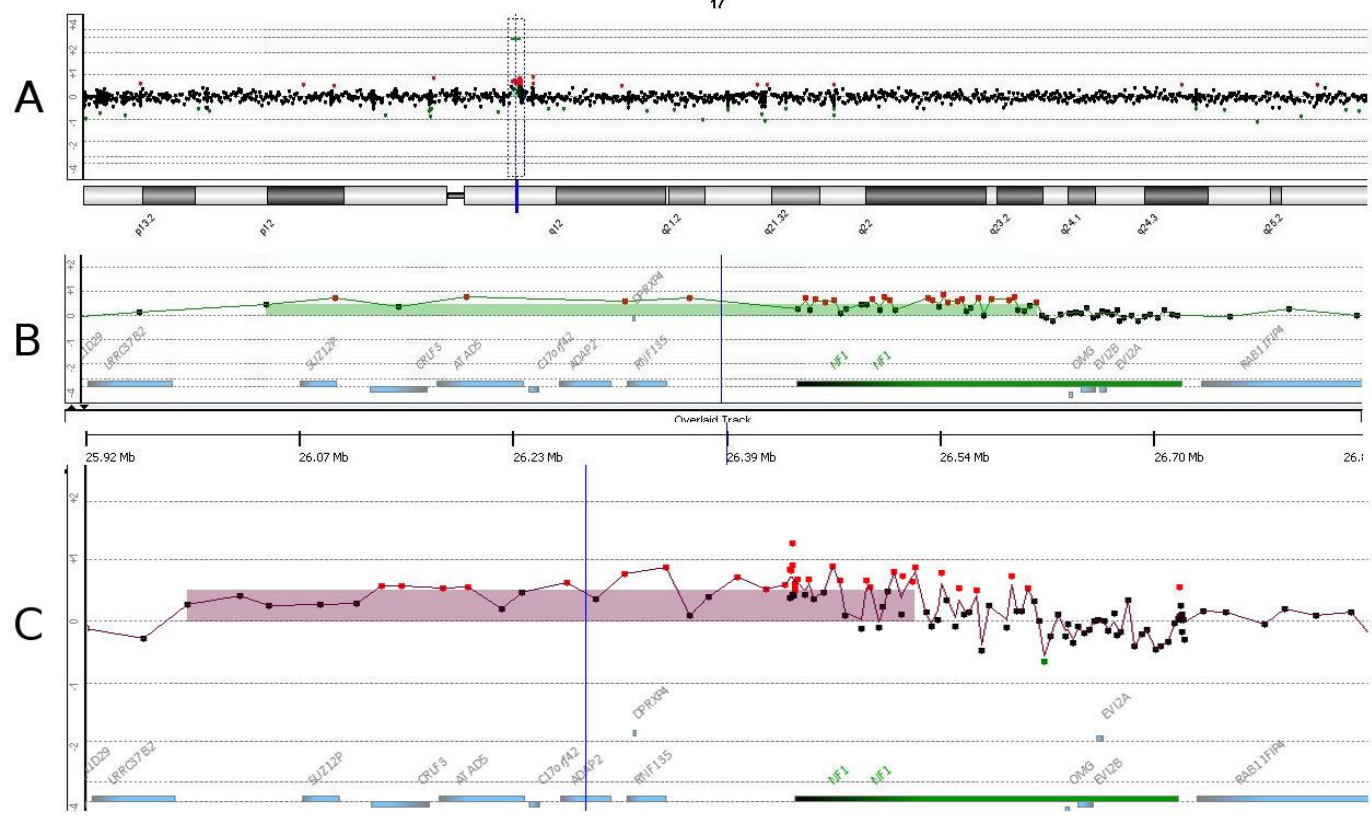

Figura 2 - Visão geral do cromossomo (A) e detalhe da duplicação (B) encontrada no array CytoSure ISCA 8x60k (OGT) da paciente 9. C - Detalhe da duplicação encontrada no array CytoSure ISCA 4x180k (OGT) do pai da paciente 9.

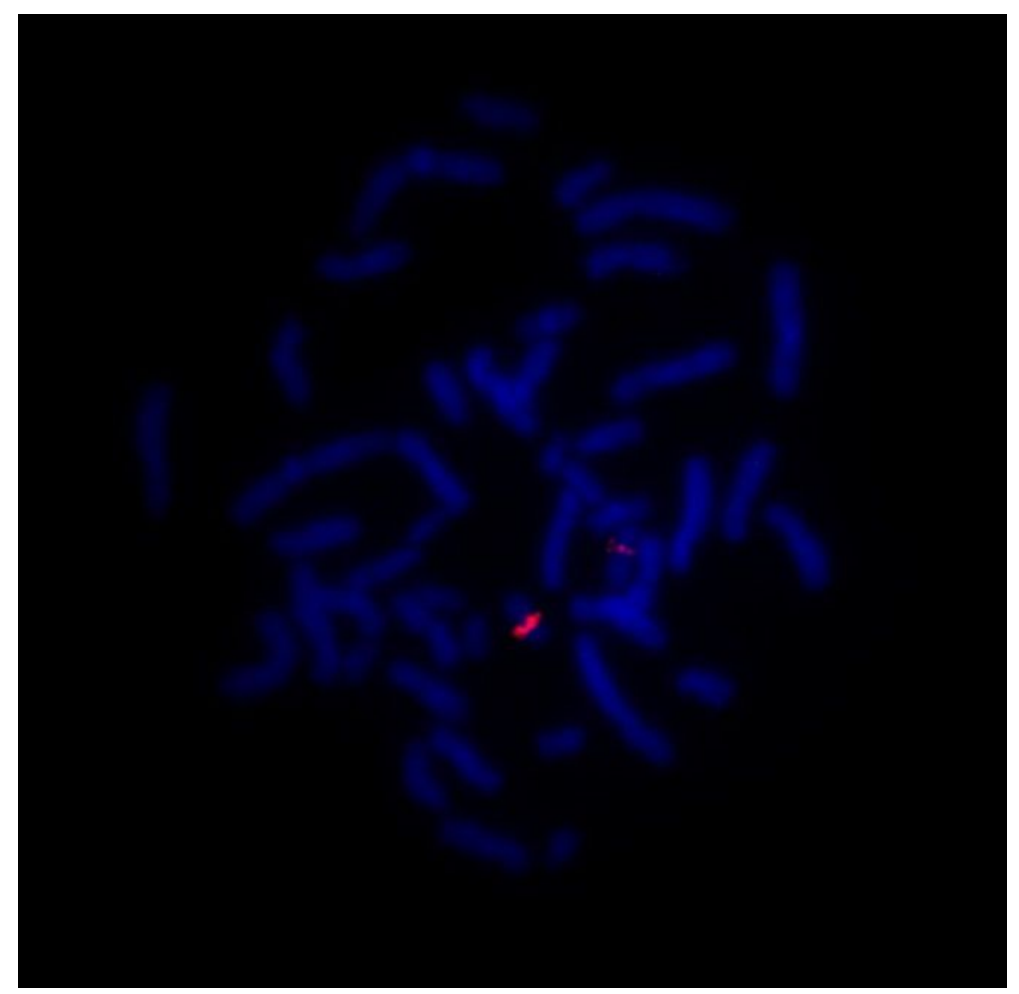

Figura 3 - FISH em metáfases do paciente 9 utilizando a sonda RP11-229K15 para o cromossomo 17q11.2, apresentando duas marcações, sendo uma de maior intensidade. 
A análise do genoma do paciente por array revelou uma duplicação de 9 genes no cromossomo 17. Esta região contém parcialmente o gene NF1 que, quando mutado, causa a neurofibromatose tipo 1 (NF1), de herança autossômica dominante. Aproximadamente $5 \%$ dos indivíduos com NF1 apresentam microdeleções envolvendo o gene NF1 e outros genes desta região, causando a síndrome de microdeleção do $N F 1$, onde o fenótipo é mais grave do que nos quadros com mutações intragênicas (Moles et al., 2012).

Dentre os genes duplicados destacamos $A D A P 2$, também conhecido como CENTA2, com uma ampla distribuição nos tecidos, sendo particularmente abundante no coração, tecido adiposo e músculo esquelético (Whitley et al., 2002). Os genes CENTA2 e JJAZ1 (este último fora da região duplicada da paciente) são significativamente expressos no coração e candidatos a serem responsáveis por anomalias cardiovasculares (Venturin et al., 2004); $D P R X P 4$, um pseudogene membro da família de genes homeobox que se acredita estar envolvido com o início do desenvolvimento embrionário; e RNF135. Douglas et al. (2007) sugerem que o gene RNF135, presente na duplicação de nossa paciente, quando em haploinsuficiência contribui para um crescimento excessivo e dismorfismos faciais, além de dificuldades no aprendizado e outras anomalias congênitas. Os autores também identificaram mutações heterozigotas neste gene em 4 de 245 indivíduos com uma síndrome de crescimento excessivo caracterizada por aumento no peso e estatura pósnatal, macrocefalia, deficiências de aprendizado e características faciais dismórficas.

Moles et al. (2012) sugerem uma hipótese interessante na qual se uma diminuição da função de RNF135 leva a um crescimento excessivo, um 
aumento de função devido a uma duplicação da região poderia ocasionar baixa estatura e microcefalia, como ocorre em sua coorte. Os autores realizaram estudos subsequentes dos pais que revelaram uma microduplicação aparentemente de novo, uma herdada do pai clinicamente normal e uma herdada da mãe com características dismórficas semelhantes às do filho. Os outros pacientes não tiveram os genitores analisados. A ocorrência de portadores saudáveis da microduplicação de $17 q$ sugere uma possível penetrância reduzida ou uma expressividade variável que pode ser modificada por fatores genéticos e não genéticos.

Grisart et al. (2008) relataram 7 membros de uma família com uma microduplicação recíproca à microdeleção de NF1 em que 5 destes apresentaram um fenótipo caracterizado por atraso no desenvolvimento, deficiência intelectual leve, dismorfismos faciais leves, hipoplasia do esmalte dentário e calvície de início precoce. Esta microduplicação também foi descrita por Lu et al., (2007) em uma paciente com atraso no desenvolvimento, deficiência intelectual, déficit pondero-estatural e microcefalia.

Buscas no DECIPHER retornaram como resultado 15 pacientes apresentando sobreposição com a região duplicada de nossa paciente, sendo que 9 pacientes possuíam uma deleção e 6 uma duplicação. Dentre esses casos, em 4 pacientes a alteração era de novo, em 2 era herdada de um dos genitores normais e em 3 era herdada de um dos pais com fenótipo similar ao da criança. Em 6 casos os pais não foram avaliados. Um paciente do sexo feminino descrito no DECIPHER portador de uma duplicação de novo no $17 q$ (29061725-30367156pb) na qual a duplicação de nossa paciente está totalmente inserida, apresenta fenótipo com obesidade generalizada, 
deficiência cognitiva e anomalias nas glândulas tireóide e paratireóide (Figura 4).

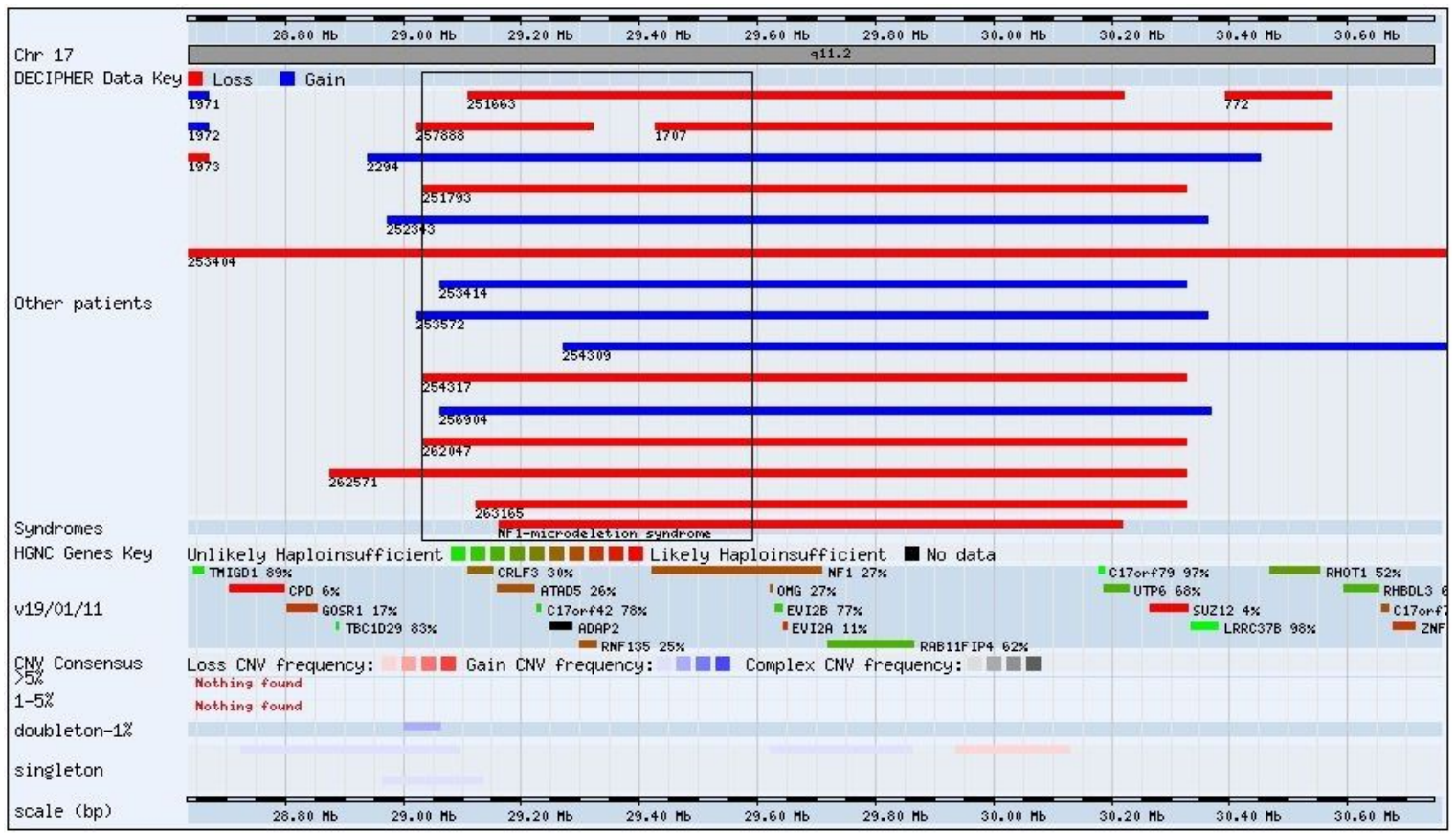

Figura 4 - Pacientes com alterações genômicas que se sobrepõem a da paciente 9. A área demarcada pelo retângulo preto é a área da alteração da paciente. Imagem retirada do DECIPHER em 03/2012.

Buscas no ISCA revelaram 14 pacientes apresentando sobreposição com a região duplicada de nossa paciente, onde 10 possuíam uma deleção, sendo 2 de novo, e 4 uma duplicação (Figura 5).

Trata-se de uma região rica em duplicações segmentares (segmental duplications), o que ajuda a explicar o número de pacientes com CNVs nesta região do genoma. 


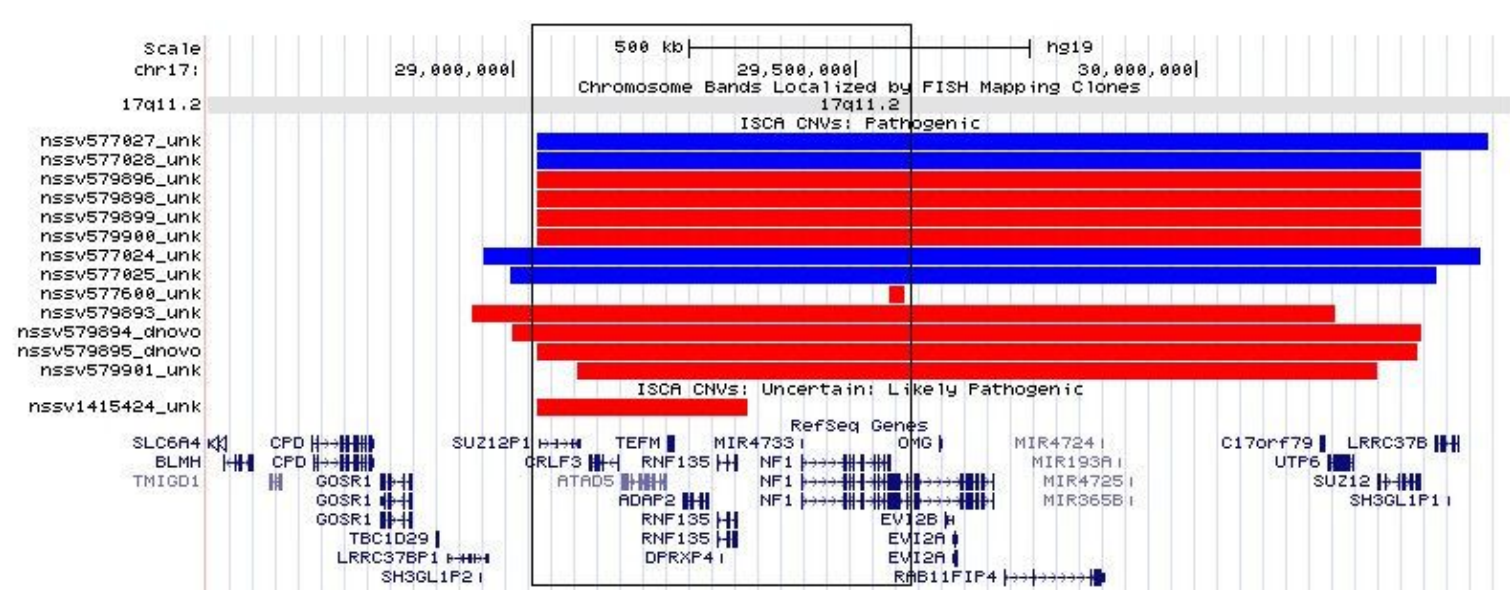

Figura 5 - Pacientes com alterações genômicas que se sobrepõem a da paciente 9. A área demarcada pelo retângulo preto é a área da alteração da paciente. Imagem retirada do UCSC Genome Browser em 05/2012.

As microdeleções de NF1 são causadas por recombinação homóloga não-alélica (NAHR) entre repetições de baixo número de cópias (low copy repeats - LCRs) que flanqueiam esta região (Moles et al., 2012). Recombinação entre as repetições diretas de LCRs próximas ao gene NF1 (NF1REP-P e -M) poderiam dar origem a microdeleções em NF1 por recombinação desigual entre cromátides-irmãs ou recombinação intracromossômica via um "looping do DNA" e excisão. Dessa forma, como as recombinações meióticas desiguais entre cromátides irmãs são a base para a microdeleção de NF1, poderia ser prevista a formação de uma duplicação recíproca (Dorschner et al., 2000).

Evidências crescentes demonstram que NAHR entre repetições altamente homólogas que flanqueiam genes sensíveis à dosagem desempenha um papel central nas doenças genômicas, resultando em duplicações ou deleções (Grisart et al., 2008). 


\section{Paciente 11}

T.C.C.P., sexo feminino, 19 anos. A paciente foi encaminhada ao nosso serviço com suspeita de obesidade sindrômica. A duração da gestação foi de 9 meses, com sangramentos no $5^{\circ}$ e $6^{\circ}$ mês. Parto cesáreo, peso ao nascimento $2250 \mathrm{~g}$ e comprimento $47 \mathrm{~cm}$. Sugou bem ao seio materno até os 10 meses. Sentou sem apoio com 8 meses, andou com 1 ano e 4 meses, começou a falar aos 9 meses.

Na ocasião da consulta apresentava a estatura 1,49 m (p<2,5), peso 107 kg (>p97) e perímetro cefálico $59 \mathrm{~cm}$ (>p98). Macrocrania. Epicanto bilateral. Hirsutismo. Mão com 15,5cm (<p3). Obesidade iniciou-se a partir dos 2 anos, tendo um grande ganho de peso de cerca de $30 \mathrm{~kg}$ em 2007. Ocorrência de psicose e alucinações. Tem atraso no desenvolvimento neuropsicomotor e dificuldade escolar. Crises convulsivas na vigência de febre.

Cariótipo 46,XX, teste de MLPA com os kits P036-E1 e P070-B1 normais.

O emprego do array CytoSure ISCA 4x180k (OGT) mostrou uma duplicação intersticial do braço curto do cromossomo 16 (p13.11p12.3) de $569 \mathrm{~kb}$ localizada em 16292245pb e 16861714pb, conforme o Ensembl Genome Browser (versão NCBI37/hg19).

O cromossomo 16 é rico em low copy repeats, sendo que na região duplicada são descritas duplicações segmentares (segmental duplications) por toda sua extensão (Figura 6).

Hannes et al. (2009) identificaram 5 pacientes com deficiência intelectual e/ou anomalias múltiplas congênitas portando uma deleção em 16p13.11 de $1.5 \mathrm{Mb}$, além de 5 controles normais (de um total de 1682 controles testados) 
portando a duplicação recíproca, ambas ocorrendo devido a recombinação homóloga não-alélica (NAHR) de low copy repeats do cromossomo 16. Dessa forma, a duplicação do nosso paciente parece ser uma variante comum na população, uma variação provavelmente benigna.

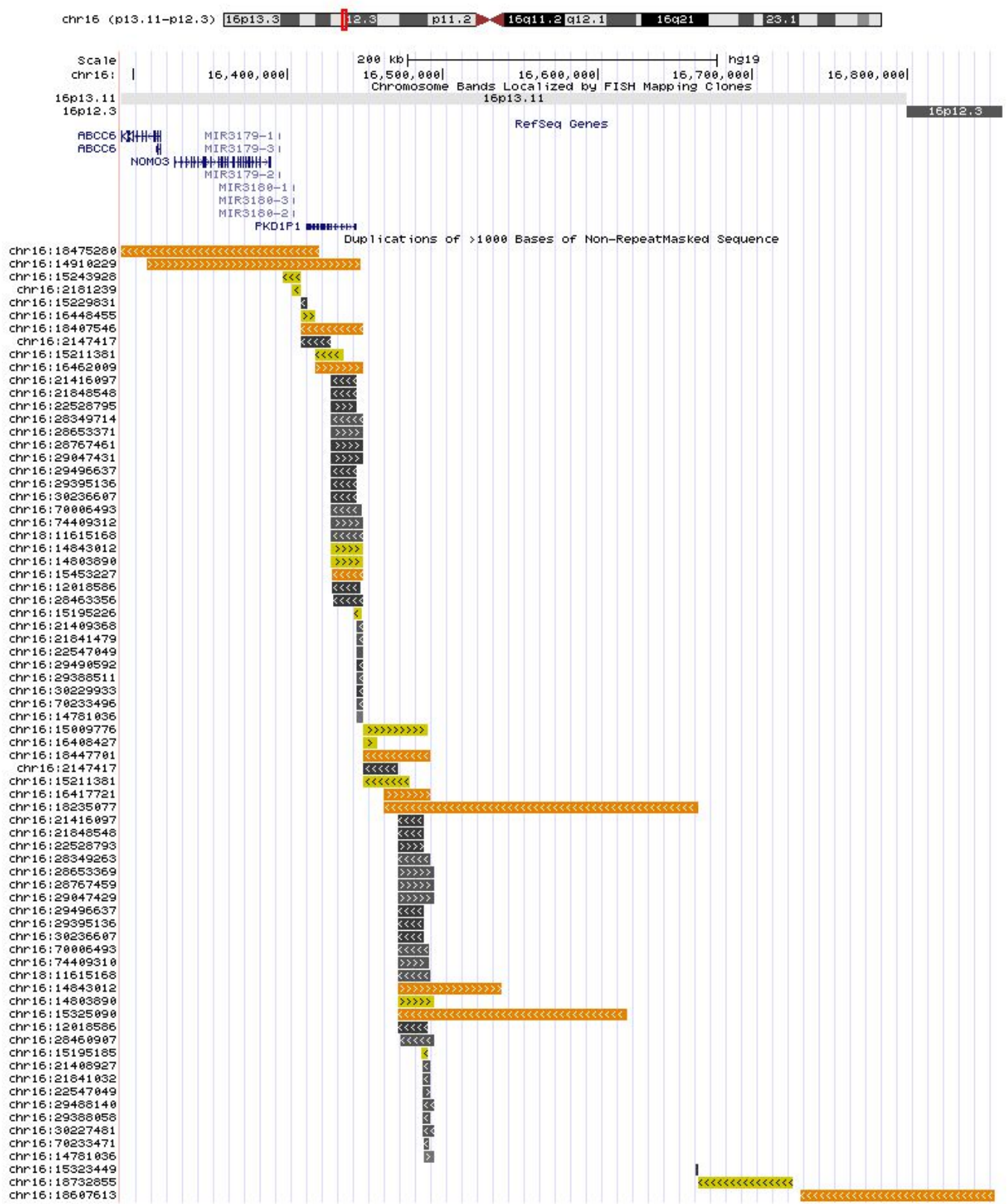

Figura 6 - 'Segmental duplications' presentes na região duplicada do paciente 11, retirada do UCSC Genome Browser em 12/2012. 


\section{Paciente 12}

P.C.B., sexo feminino, 11 anos. Pai com 46 e mãe com 48 anos. Sem irmãos. A paciente foi encaminhada ao nosso serviço com suspeita de síndrome de Prader-Willi. A duração da gestação foi de 37 semanas, parto normal, peso ao nascimento $3000 \mathrm{~g}$ e comprimento $49 \mathrm{~cm}$. Apresentou movimentos fetais normais e tinha boa sucção. Mãe fez mastectomia devido a um câncer e submeteu-se a exames radiológicos para acompanhamento antes e após a gravidez. Firmou a cabeça com 3 meses, sentou sem apoio com 8 meses, andou com 1 ano e 4 meses, elaboração de frases mais completas e entendíveis por volta dos 7 anos e 6 meses, mas ainda apresenta problemas de articulação da fala. Dificuldades na leitura, escrita e cálculos.

$\mathrm{Na}$ ocasião da consulta apresentava a estatura 1,45 m (p2,5-p10), peso 54,1 kg (p90-p95) e perímetro cefálico 49,5 cm (p10). Teve rápido ganho de peso entre 1 e 6 anos de idade com obesidade central devido à hiperfagia. Problemas de comportamento como teimosia, acessos de violência, variações rápidas de humor, comportamento obsessivo/compulsivo, mentiras e roubos. Hipogenitalismo com hipoplasia de pequenos lábios. Distúrbios do sono, fazendo tratamento com Psiquiatra. Mãos e pés pequenos e dedos afilados nas pontas. Alto limiar para a dor. Apresenta dificuldade na capacidade de vomitar.

Exames neuro-musculares normais.

Estudo do padrão de metilação da região PWS/AS e teste de MLPA com o kit P064-B2 normais.

O emprego do array CytoSure ISCA 4x180k (OGT) mostrou uma duplicação intersticial do braço longo do cromossomo 7 (q36.2) de 398kb 
localizada em 154607289pb e 155005535pb, conforme o Ensembl Genome Browser (versão NCBI37/hg19) (Figura 7).

O gene DPP6, parcialmente duplicado em nosso paciente, desempenha um papel importante na regulação da proliferação e migração de neurônios na neurogênese, provavelmente através da participação na excitabilidade neuronal elétrica, integração sináptica e plasticidade (Liao et al., 2013). Estes autores descreveram dois pacientes que portavam uma deleção (de $336 \mathrm{~kb}$ e $362 \mathrm{~kb})$ no cromossomo $7 \mathrm{q} 36$ que abrangia o gene DPP6. Ambos apresentavam baixa estatura, baixo peso, microcefalia e deficiência intelectual moderada. Também identificaram em 4 indivíduos de uma mesma família uma mutação missense neste gene sendo que os portadores da mutação apresentavam microcefalia e deficiência intelectual em graus variados. DPP6 também tem sido identificado como um potencial candidato para o autismo (Marshall et al.,2008).

Van Es et al. (2008) demonstraram a associação de uma variante no gene DPP6 como uma possível causa da esclerose lateral amiotrófica. Já Alders et al. (2009) identificaram uma mutação upstream ao gene DPP6 em 3 indivíduos de uma família e em outros 7 pacientes independentes que apresentavam fibrilação ventricular idiopática. Os autores propuseram que o mecanismo patogênico para esta doença seja a superexpressão de DPP6.

O gene HTR5A é um receptor de serotonina sendo que as variantes deste gene estão fortemente associadas com altos níveis plasmáticos de triglicérides em uma população do norte da Europa, sugerindo regulação dos níveis plasmáticos de triglicérides pelo cérebro (Zhang et al., 2010). 
Buscas no DECIPHER e ISCA retornaram em torno de 70 pacientes com CNVs nessa região, sendo que a maioria apresentava deleções que cobriam a região estudada. Diversos pacientes apresentavam deficiência intelectual e, entre os seis que portavam a duplicação na região $7 q 36.2$ descritos no DECIPHER, um apresentava microcefalia e outro baixa estatura, além de outras características.

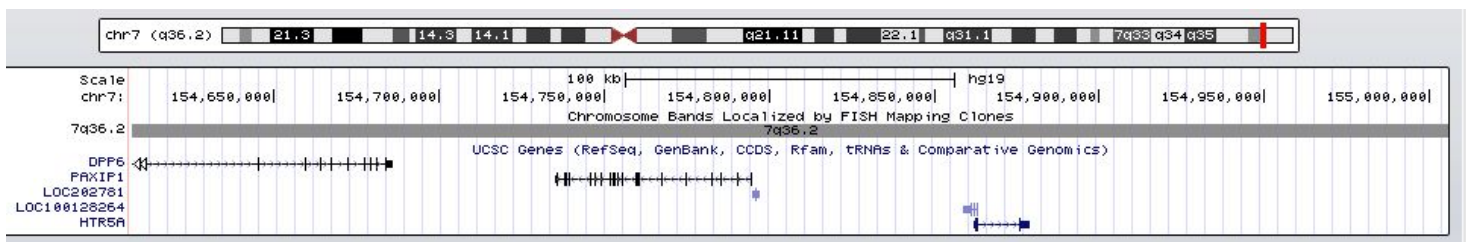

Figura 7 - Ilustração dos genes duplicados da região $7 q 36.2$ da paciente 12 . 0 retângulo vermelho destaca a região duplicada. Retirado do UCSC Genome Browser em 01/2014.

Estudos complementares para validação desse resultado serão realizados posteriormente. 


\section{Paciente 16}

B.H.M.S., sexo masculino, 10 anos. Pais com 32 anos de idade, nãoconsanguíneos. Pai nasceu com pé torto congênito. Pai e paciente apresentam traço falcêmico. Irmã com 3 anos (nascida aos 7 meses; teve problemas pulmonares, ficou em coma por 22 dias, teve 3 paradas cardíacas; no retorno da consulta do paciente foi observado que a irmã de 5 anos apresentava problemas de articulação da fala). O paciente foi encaminhado ao nosso serviço com suspeita de síndrome de Prader-Willi. A gestação durou 6 meses, ocorrendo perdas sanguíneas ao $3^{\circ}$ mês. Parto cesáreo devido à hipertensão e diabetes da mãe, peso ao nascimento $2200 \mathrm{~g}$ e comprimento $39 \mathrm{~cm}$. Chorou, sem sucção, mãe alimentava-o com seringa. Sugou apenas com 4 meses. Hipotonia neonatal. Firmou a cabeça com 1 ano e 6 meses, sentou sem apoio com 2 anos e 3 meses, elaboração de frases com aproximadamente 9 anos; sem controle esfincteriano. Nasceu com pé torto congênito, operando aos 2 anos e 7 meses; após a cirurgia começou a andar. Está na escola desde o berçário, porém não lê, não escreve e não faz contas. Problemas de articulação da fala. Teve pneumonia aos 6 anos e foi diagnosticado que o coração é aumentado em relação ao tamanho normal. Episódios de convulsão com 15 dias, 20 dias, 1 ano, 4 anos e 7 anos.

Na ocasião da consulta (23/05/2011) apresentava a estatura $1,23 \mathrm{~m}$ (p2,5-p10), peso $46 \mathrm{~kg}$ (p95-p97) e perímetro cefálico $54 \mathrm{~cm}$ (p75-p90). Braquicefalia, abaulamento frontal, fronte baixa e estreita. Implantação baixa de cabelos na fronte e nuca. Hemangiomas na fronte e na nuca. Orelhas grandes com lóbulo preso. Sinofre e epicanto bilateral. Miopia e hipermetropia. Nariz grande com hipoplasia alar. Lábio superior e inferior grossos, palato alto e 
estreito, filtro longo. Início da dentição aproximadamente aos 7 meses. Pescoço curto. Hipogenitalismo. Fez cirurgia para correção da criptorquidia bilateral. Mãos pequenas com clinodactilia no $5^{\circ}$ dedo.

Problemas de alimentação na infância tendo posteriormente um rápido e excessivo ganho de peso entre 1 e 6 anos devido à hiperfagia. Distúrbios de comportamento como teimosia, acessos de violência, variações rápidas de humor, comportamento obsessivo/compulsivo.

Distúrbios do sono, sendo que quase não dorme. Alto limiar para a dor e instabilidade de temperatura corpórea. Habilidade em montar quebra-cabeças.

No retorno para coleta de material para estudo citogenético (05/08/2013) o paciente apresentava estatura 1,40 m (p10-p25) e peso 61,8 kg (p95-p97). Houve um aumento da miopia para 5 graus, aumento da agressividade e permanece com distúrbios do sono, tendo apenas cochilos de 5-6 minutos durante o dia. Além disso, ocorreu um episódio de convulsão em julho.

Estudo do padrão de metilação da região PWS/AS e teste de MLPA com o kit P064-B2 normais.

O emprego do array CytoSure ISCA 4x180k (OGT) mostrou uma deleção intersticial do braço longo do cromossomo 3 (q25.33q26.1) de 1.3Mb localizada em 159252702pb e 160555217pb (Figuras 8 e 9). Também foi detectada uma deleção intersticial do braço longo do cromossomo 13 (q31.2q32.1) de 5.59Mb localizada em 89476229pb e 95065310pb (Figuras 10 e 11), conforme o Ensembl Genome Browser (versão NCBI37/hg19). 


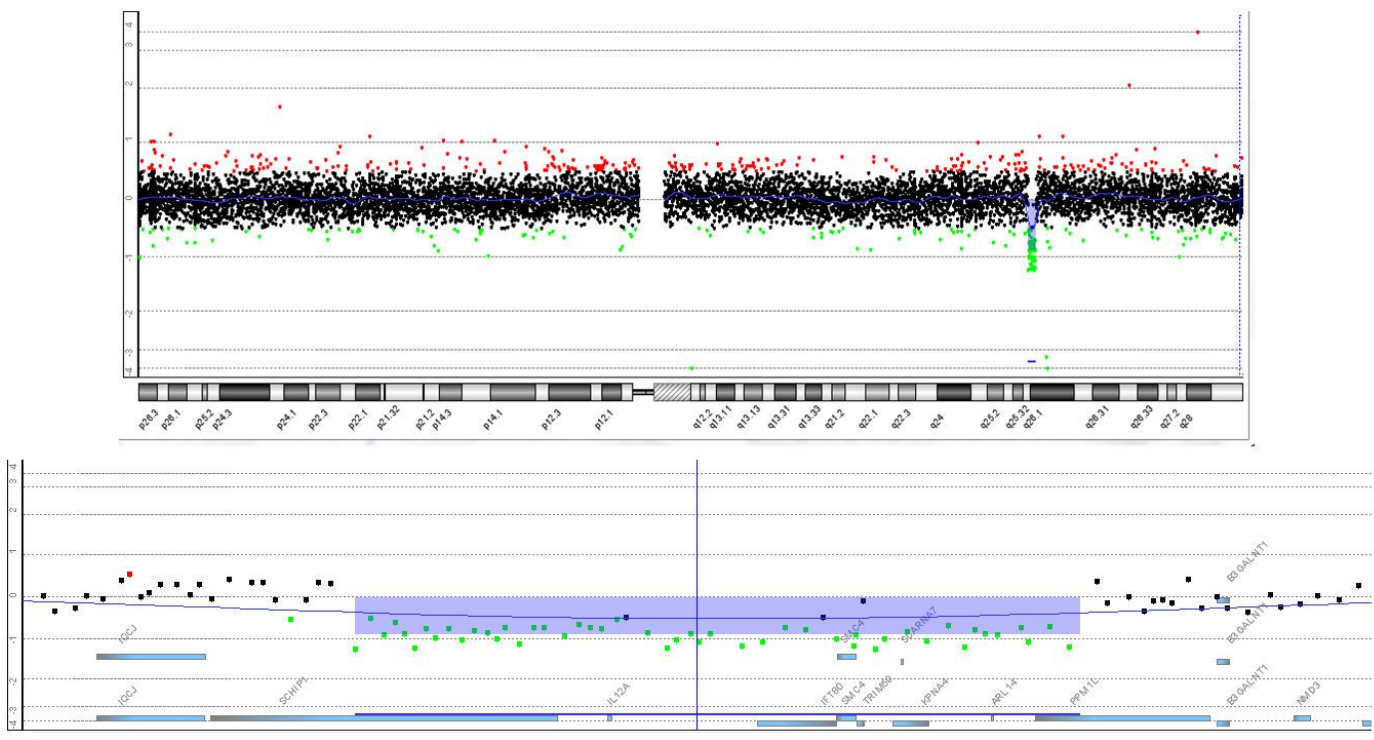

Figura 8 - Visão geral do cromossomo 3 e detalhe da deleção encontrada no array CytoSure ISCA 4x180k (OGT) do paciente 16.

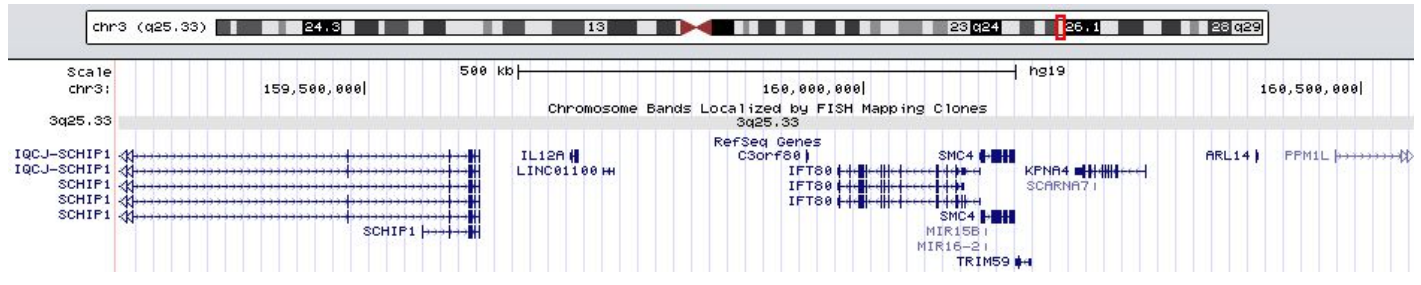

Figura 9 - Ilustração dos genes deletados da região 3q25.33-q26.1 do paciente 16. 0 retângulo vermelho destaca a região deletada. Retirado do UCSC Genome Browser em 10/2012. 


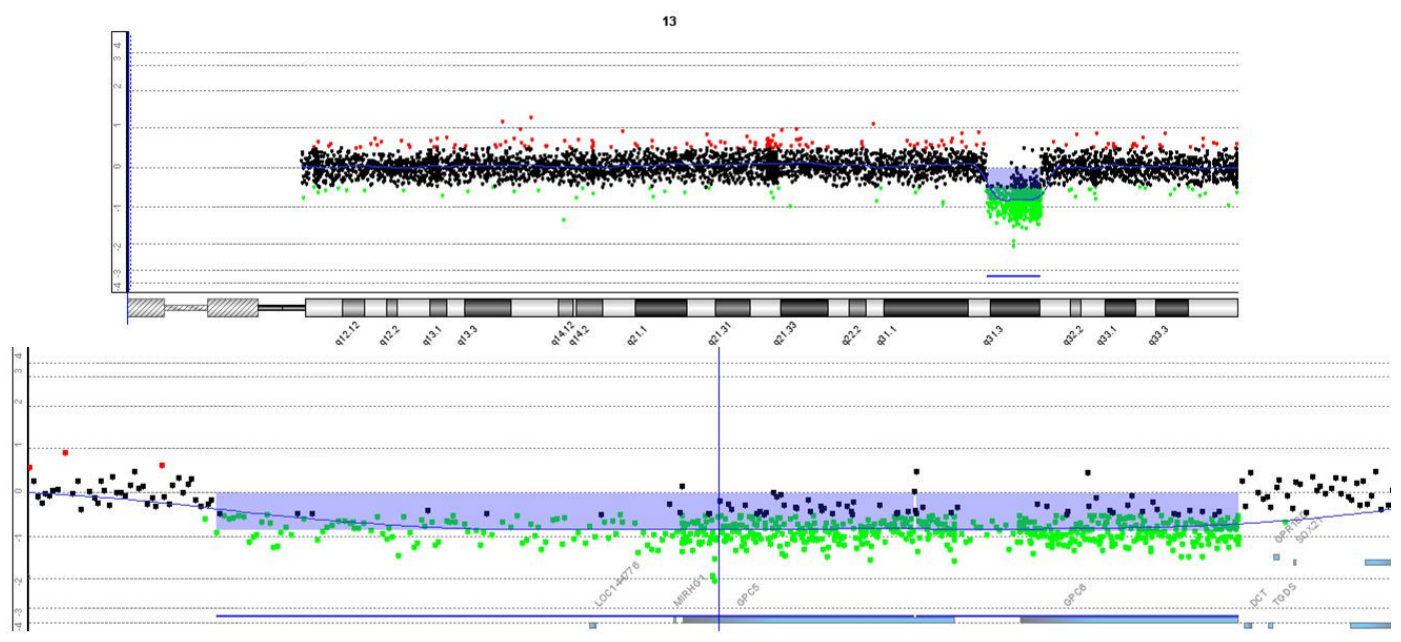

Figura 10 - Visão geral do cromossomo 13 e detalhe da deleção encontrada no array CytoSure ISCA 4x180k (OGT) do paciente 16.

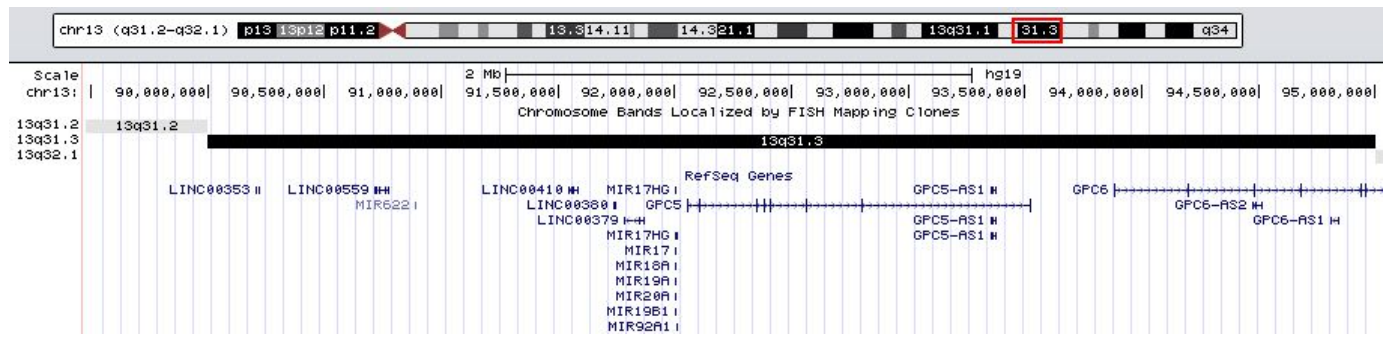

Figura 11 - llustração dos genes deletados da região 13q31.2-q32.1 do paciente 16. 0 retângulo vermelho destaca a região deletada. Retirado do UCSC Genome Browser em 10/2012.

Para a confirmação dos dados encontrados no array procedeu-se a hibridação in situ fluorescente com a sonda RP11-67F24 para o cromossomo 3q26.1, onde se observou uma marcação vermelha, e a sonda RP11-632L2 para o cromossomo 13q31.3, onde se observou uma marcação verde (Figura 12). O cariótipo apresentou resultado $46, X Y$. Os genitores também foram estudados com essas sondas, ambos com duas marcações para o cromossomo 3 e duas marcações para o cromossomo 13 (Figuras 13 e 14). 


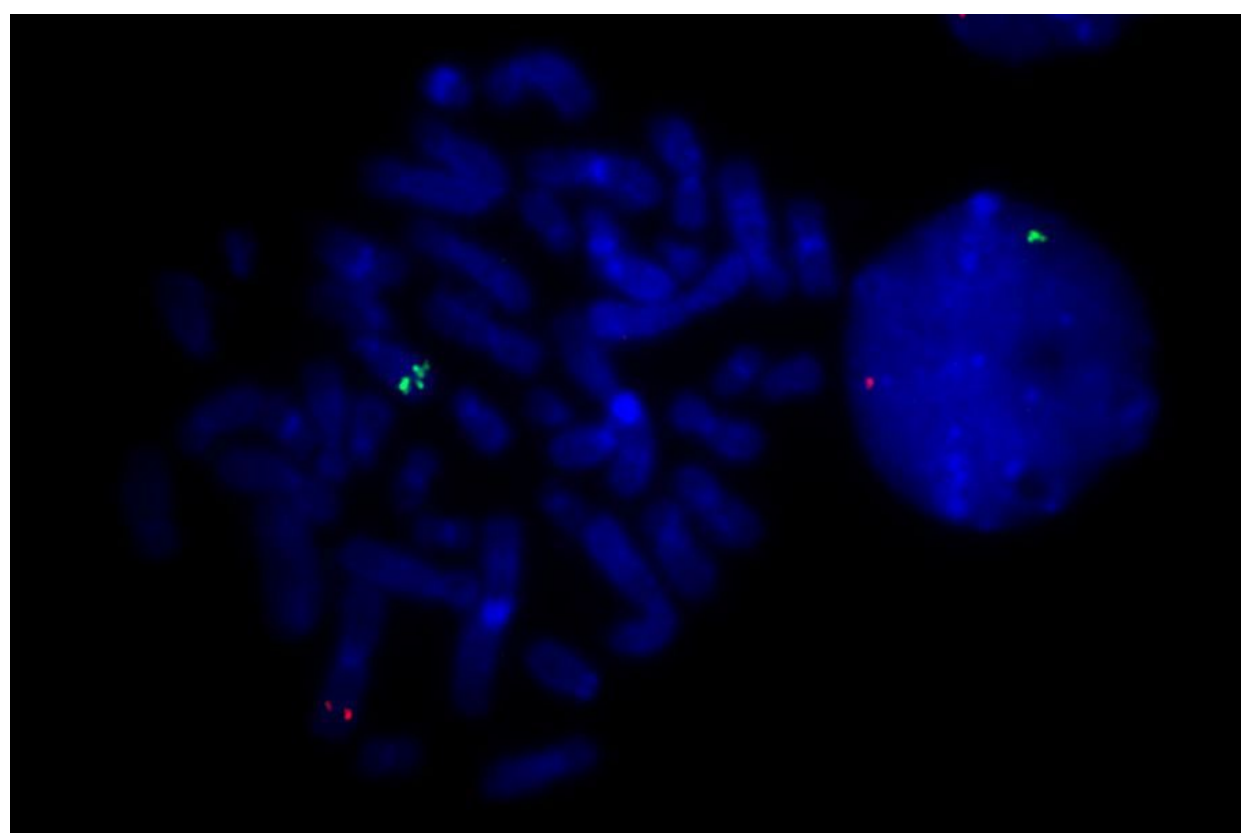

Figura 12 - FISH em metáfases do paciente 16 utilizando a sonda RP11-67F24 para o cromossomo 3q26.1, onde se observou uma marcação vermelha, e a sonda RP11-632L2 para o cromossomo 13q31.3, onde se observou uma marcação verde.

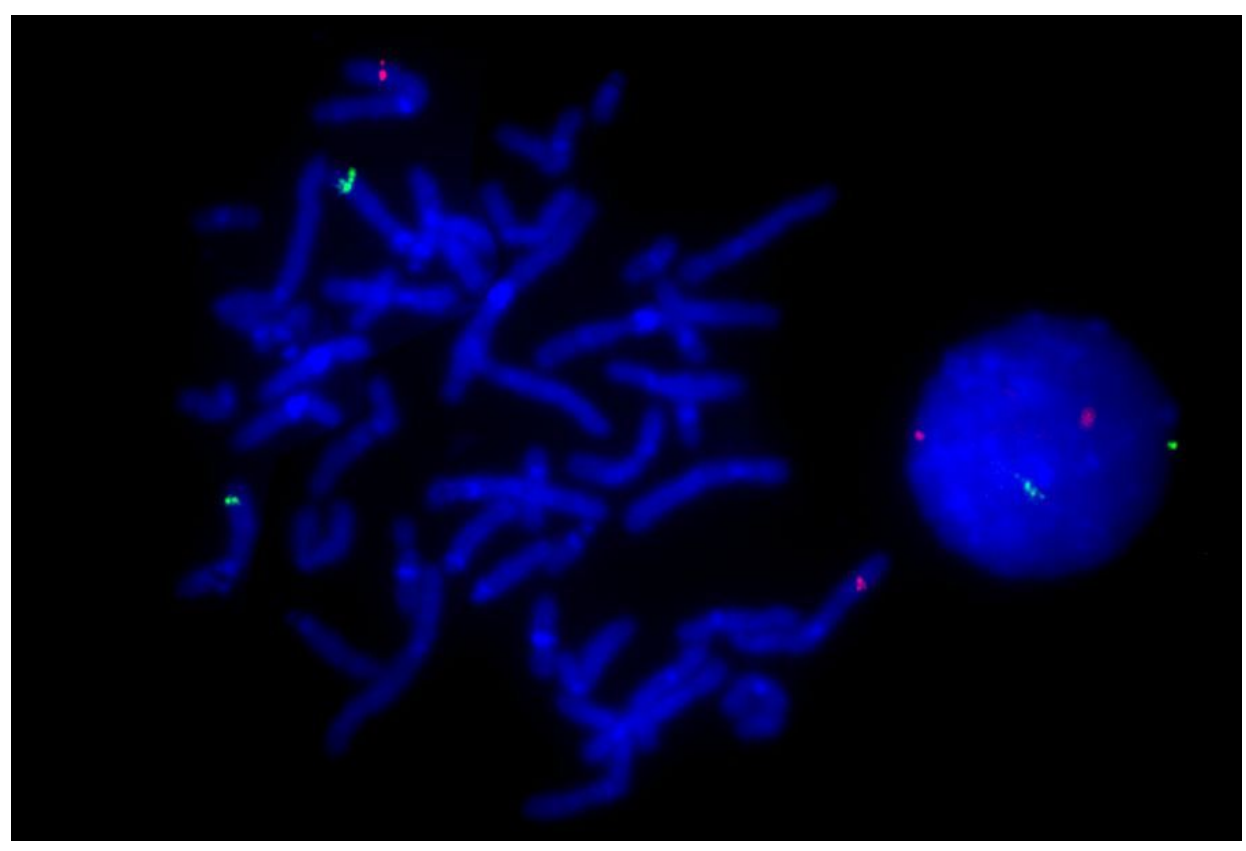

Figura 13 - FISH em metáfases da mãe do paciente 16 utilizando a sonda RP11-67F24 para o cromossomo 3q26.1, onde se observou duas marcações vermelhas, e a sonda RP11-632L2 para o cromossomo 13q31.3, onde se observou duas marcações verdes. 


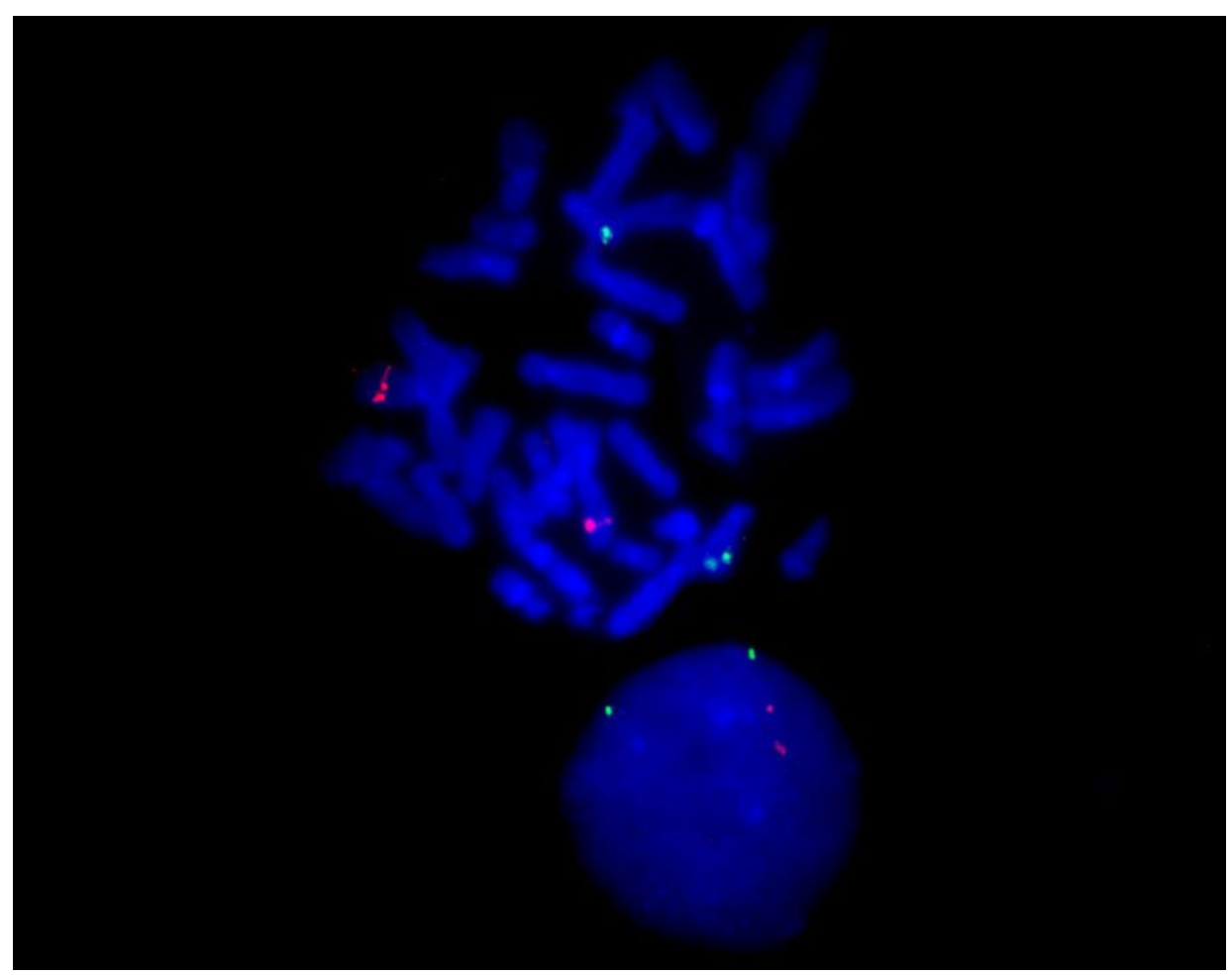

Figura 14 - FISH em metáfases do pai do paciente 16 utilizando a sonda RP11-67F24 para o cromossomo 3q26.1, onde se observou duas marcações vermelhas, e a sonda RP11-632L2 para o cromossomo 13q31.3, onde se observou duas marcações verdes.

A região terminal do braço longo do cromossomo 3 (3q26-qter) já foi descrita como portando diversos genes candidatos, como GLUT2, PIK3CA, $A P O D, A P M 1$, para doença coronária, risco cardiovascular, resistência à insulina, diabetes mellitus e obesidade (Chiodini \& Lewis, 2003), entretanto, esta região não se sobrepõe à região deletada do paciente estudado.

Dentre os genes deletados estão o gene SMC4 que faz parte da família SMC, onde atua como membro da manutenção estrutural dos cromossomos, e tem o papel de reparo de DNA em mamíferos; ARL14 participa da regulação do tráfico de proteínas intracelulares e membranas e da remodelação do citoesqueleto e está expresso em células do sistema imunológico; e IL12, que 
codifica uma subunidade de uma citocina que atua sobre células T e natural killer, além de uma ampla gama de atividades biológicas.

Chen et al. (2008) compararam o peso, massa de gordura, níveis de insulina e glicose, pressão arterial e outras medidas bioquímicas no sangue de camundongos $\mathrm{Ppm}_{1 \mathrm{I}^{-/}}$e selvagens. Os camundongos knockout eram 19,3\% mais pesados, com um aumento de $46,7 \%$ de massa gorda com 20 semanas de idade, níveis de insulina e pressão arterial aumentados e diminuição significativa de ácidos graxos livres comparados aos controles do tipo selvagem. Ppm1/ foi identificado e validado como um gene capaz de modular vários traços de obesidade, diabetes e hipertensão. Nosso paciente apresenta apenas uma cópia inteira deste gene, pois a outra está rompida devido à deleção.

Buscas no DECIPHER retornaram 3 pacientes com perdas cromossômicas na região do cromossomo 3 que se sobrepõem ao do nosso paciente. Um dos pacientes (278461) apresentava atraso no desenvolvimento da fala e linguagem, dificuldades de aprendizado, nevo pigmentado, manchas "Cafe-au-lait" e crescimento excessivo. Outro paciente (257440) apresentava macrocefalia e deficiência intelectual.

Dois trabalhos de 2009 fazem a correlação de deleções no braço longo do cromossomo 13 com o fenótipo. Quélin et al. (2009) citou 12 pacientes (9 eram fetos que não terminaram o desenvolvimento e 3 eram crianças) com deleções de diversos tamanhos do cromossomo 13, sendo as principais características clínicas deficiência intelectual, atraso no crescimento, dismorfismo craniofacial e diversos defeitos congênitos. Seis pacientes apresentaram defeitos dos membros superiores, especialmente envolvendo 
malformações digitais. Os autores sugeriram GPC5 como um gene candidato dentro da banda 13q31.3 para as malformações dos dedos, pois está envolvido na regulação do crescimento celular e morfogênese e foi demonstrado em camundongos a expressão de GPC5 no sistema nervoso central, rins e membros.

Outro estudo determinou os pontos de quebra em 14 pacientes com deleções parciais desta região (Kirchhoff et al., 2009). Todos os pacientes apresentaram hipotonia, além de alguns terem hiperatividade, comportamento agressivo e episódios de epilepsia. Todos os pacientes deste estudo apresentaram deficiência intelectual em um nível variando de moderado a grave, sem que pudesse ser feita alguma correlação entre a deleção e o grau da deficiência intelectual. Os autores também refinaram a menor região ligada à baixa estatura, na banda 13q31.3 (89.5-91.6 Mb) entre diversas outras características.

O paciente com a deleção que mais se assemelha à de nosso paciente, na região 13q31.3-q33.1 (89,550,674-102,678,145pb), tinha 28 anos de idade e algumas características como hipotonia, baixa estatura, braquicefalia, abaulamento frontal, epicanto, palato alto, hiperatividade, comportamento agressivo e deficiência intelectual moderada que convergem com as características fenotípicas de nosso paciente. 


\section{Paciente 19}

M.S.C., sexo feminino, 15 anos. Pai com 40 e mãe com 37 anos. Uma irmã de 19 anos, saudável. Sem abortos. A paciente foi encaminhada ao nosso serviço com suspeita de síndrome de Prader-Willi. A gestação durou 9 meses. Parto cesáreo por falta de dilatação, peso ao nascimento $3650 \mathrm{~g}$. Não chorou, suç̧ão normal. Sentou sem apoio com mais de 1 ano, andou com 2 anos, elaboração de frases em torno dos 2 anos, controle esfincteriano aos 3 anos e 6 meses. Em escola especial a partir dos 5 anos, tendo problemas de aprendizado (não lê, não escreve e não faz contas).

$\mathrm{Na}$ ocasião da consulta apresentava a estatura 1,62 m (p50-p75), peso $97,3 \mathrm{~kg}(p>97,5)$ e perímetro cefálico $59 \mathrm{~cm}(p>97,5)$. Hipotonia. Braquicefalia, fronte alta, fontanela anterior persistente. Pescoço grosso. Hélices auriculares espessas. Nistagmo quando criança, miopia com 14 graus no olho direito e 12,5 graus no olho esquerdo. Filtro bem desenhado. Inicio da dentição aos 5 meses e segunda dentição aos 7 anos. Genitais normais; menarca aos 10 anos. Mãos com $17 \mathrm{~cm}$, clinodactilia e encurtamento do $5^{\circ}$ dedo em ambas as mãos. Marcha normal. Fala bastante. Rápido ganho de peso a partir dos 10 anos, com hiperfagia, obsessão por comida. Problemas de comportamento, principalmente auto-agressão. Não tem distúrbios do sono. Possui alto limiar para a dor. Nunca vomitou. Teve convulsão uma vez, passando a tomar fluoxetina (sic).

Cariótipo 46,XX. Estudo do padrão de metilação da região PWS/AS e teste de MLPA com os kits P036-E1, P070-B1 e P064-B2 normais.

O emprego do array CytoSure ISCA 4x180k (OGT) mostrou uma deleção intersticial do braço curto do cromossomo 1 (p22.1p21.2) de 5.93Mb 
localizada em 93919217pb e 99846176pb, conforme o Ensembl Genome Browser (versão NCBI37/hg19) (Figura 15).

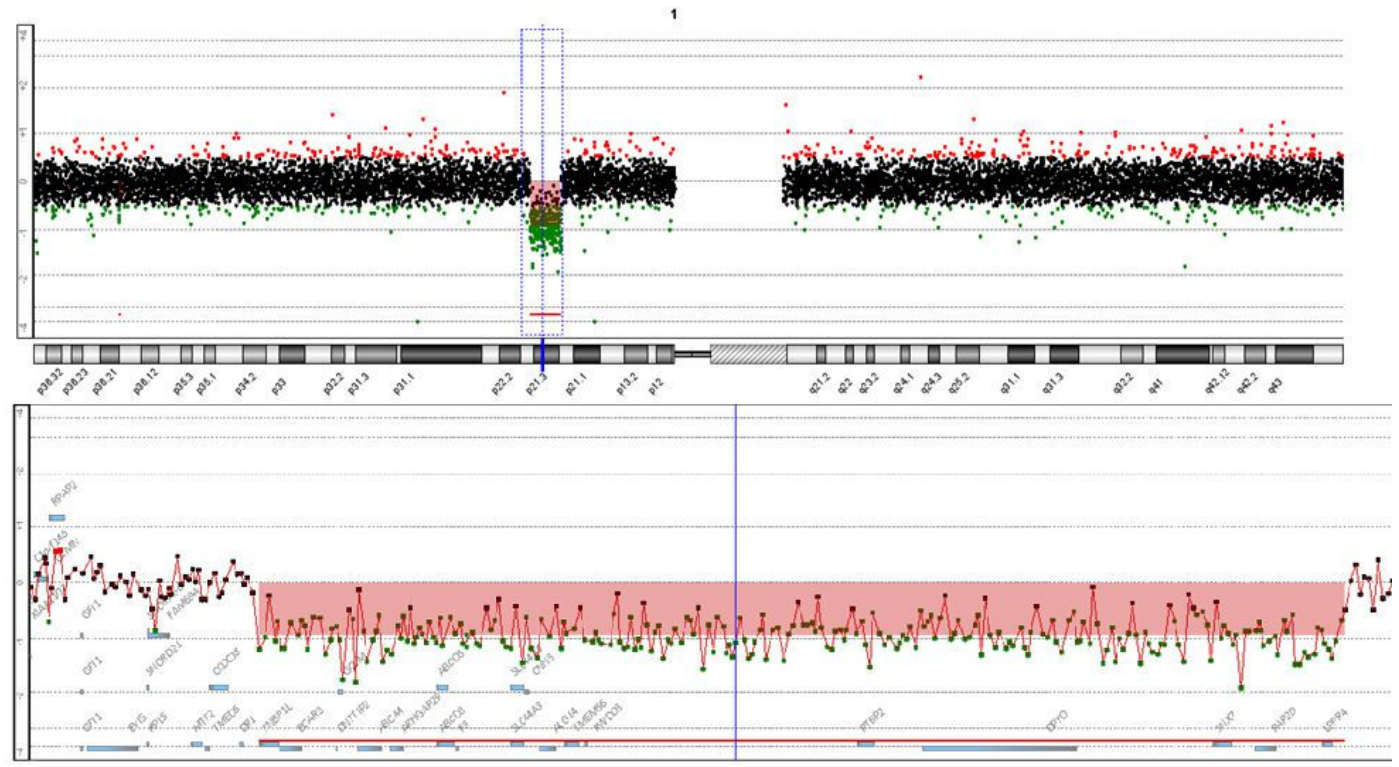

Figura 15 - Visão geral do cromossomo 1 e detalhe da deleção encontrada no array CytoSure ISCA 4x180k (OGT) do paciente 19.

Para a confirmação dos dados encontrados no array procedeu-se a hibridação in situ fluorescente com a sonda RP11-146P11 para o cromossomo 1p21.3, onde se observou uma marcação vermelha (Figura 16). Os genitores também foram estudados com essa sonda, sendo que o pai apresentou duas marcações para o cromossomo 1, porém não foi possível verificar a alteração no genoma materno pois houve falha nas tentativas de hibridação.

A deleção inclui o gene PTBP2 cujo loci foi associado com IMC em um estudo envolvendo 249.796 indivíduos (Speliotes et al., 2010). Este gene controla algumas proteínas envolvidas com a regulação de splicing e é principalmente expresso no cérebro. 
Willemsen et al. (2011) identificou em 3 irmãos e 2 pacientes não relacionados com deficiência intelectual leve uma deleção no cromossomo 1 cuja menor região de sobreposição inclui o gene DPYD e o microRNA MIR137, sendo que um paciente também apresentava deleção do gene PTBP2. Todos apresentavam dismorfismos faciais leves, e 4 dos pacientes eram obesos ou com tendência à obesidade. Carter et al. (2011) descreveram 4 pacientes com deleções totais ou parciais do gene DPYD que possuíam diagnóstico de transtorno do espectro autista (TEA). Dois pacientes apresentavam deficiência intelectual e um desses pacientes também apresentava comportamento agressivo. Os autores especularam que a deficiência da enzima dihidropirimidina desidrogenase resultante da tradução desse gene, que é crucial no neurodesenvolvimento, pode causar uma série de fenótipos neurológicos e comportamentais, incluindo TEA, epilepsia, anormalidades no tônus muscular e deficiência intelectual, principalmente quando ocorre em homozigoze. A deficiência da enzima dihidropirimidina desidrogenase é uma rara doença autossômica recessiva da via de degradação da pirimidina e pode levar a deficiências intelectual e motora e convulsões (van Kuilenburg et al., 2009). 
$\mathbf{A}$

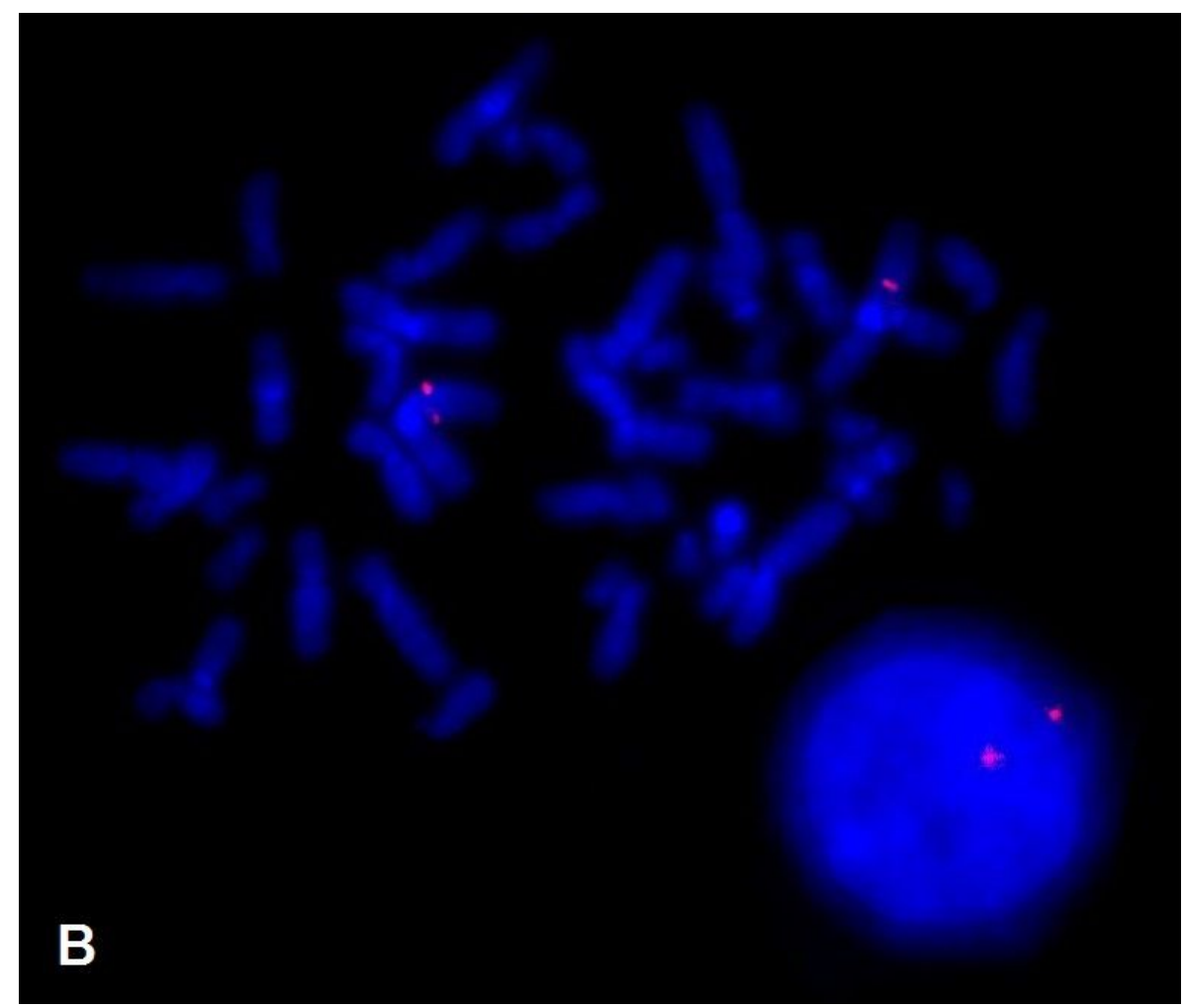

Figura 16 - FISH utilizando a sonda RP11-146P11 para o cromossomo 1p21.3, apresentando uma marcação no paciente 19 (A) e duas marcações no pai do paciente 19 (B). 
MicroRNAs são RNAs não-codificantes de aproximadamente 20 a 24 nucleotídeos que estão envolvidos na regulação pós-transcricional de genes em organismos multicelulares, levando a repressão traducional ou degradação do mRNA. Eles estão criticamente envolvidos com a patogênese do câncer, atuando como oncogenes ou supressores de tumor, como é o caso do MIR137, envolvido com o desenvolvimento de melanoma e carcinoma, entre outros (Deng et al. 2011). Este microRNA tem função no controle do ciclo celular. MIR-137 pode também desempenhar um papel importante na etiologia genética da esquizofrenia por regular a expressão de genes associados à doença, que estão envolvidos no desenvolvimento neural e função cerebral. Dessa maneira, Wright et al. (2013) propuseram que a expressão anormal deste microRNA pode levar à formação anormal de sinapses que poderia desempenhar um papel nos déficits cognitivos, sintomas psicóticos, e anormalidades estruturais do cérebro encontrados nestes pacientes.

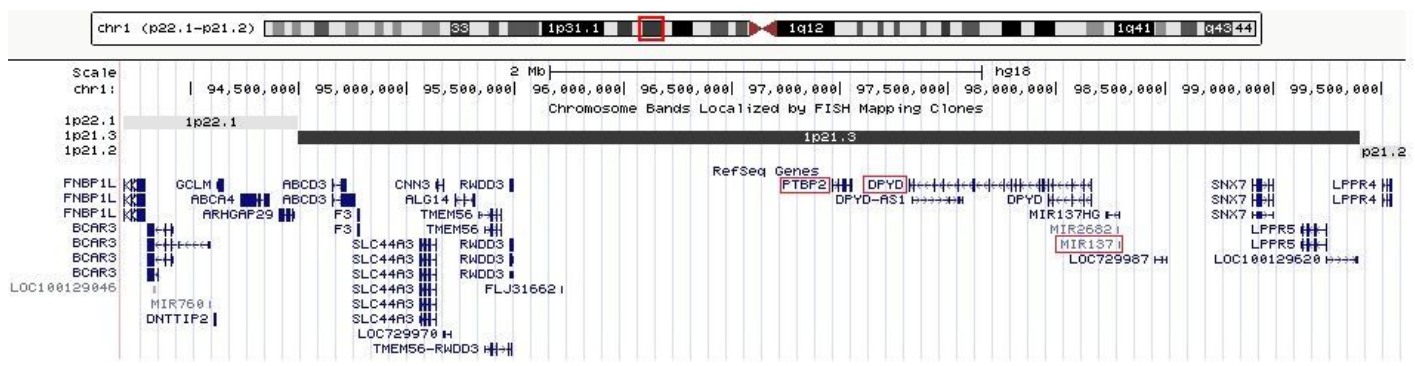

Figura 17 - Ilustração dos genes deletados em 1p22.1p21.2 do paciente 19. Em destaque nos retângulos vermelhos os genes e micro RNA associados com obesidade e deficiência intelectual. Retirado do UCSC Genome Browser em 08/2012. 


\section{Paciente 20}

J.P.P.M., sexo masculino, 6 anos. Pai com 41 e mãe com 30 anos. Sem irmãos. Mãe teve 11 abortos espontâneos, todos malformados. Nega consanguinidade. Uma prima com síndrome de Down e um primo com síndrome de Tourette, ambos parentes da mãe. O paciente foi encaminhado ao nosso serviço com suspeita de síndrome de Prader-Willi. A gestação durou 8 meses, com febre e perda sanguínea devido a placenta prévia no $4^{\circ}$ mês e infecção urinária por todo o período. Parto normal com duração de 9 horas, peso ao nascimento $4030 \mathrm{~g}$, comprimento $48 \mathrm{~cm}$, perímetro cefálico $36 \mathrm{~cm}$. Sem choro e sucção. Hipotonia. Infecção por Candida albicans gerando desconforto respiratório logo após o nascimento, havendo necessidade de ser entubado. Hipoglicemia. Firmou a cabeça com 1 ano e 4 meses. Sentou sem apoio aos 2 anos e 6 meses. Começou a andar com mais de 4 anos, com o auxílio de andador, que não utiliza mais. A partir dos 5 anos começou a formar frases. Entrou na escola aos 5 anos. Dificuldades de aprendizado (não lê, não escreve e não faz contas). Atraso no desenvolvimento neuropsicomotor. Não tem controle esfincteriano. Trombose no braço desde nascimento, ocasionalmente apresentando inchaço e veias aparentes.

$\mathrm{Na}$ ocasião da consulta apresentava a estatura 1,31 m ( $p>97,5)$, peso $57,4 \mathrm{~kg}(p>97,5)$ e perímetro cefálico $55 \mathrm{~cm}(p>97,5)$. Pescoço curto e grosso. Orelhas grandes $(7,5 \mathrm{~cm})$ com lóbulo preso. Nariz pequeno, em bico. Lábio superior fino, palato alto. Início da dentição aos 9 meses e $2^{\mathrm{a}}$ dentição com 4 anos. Hipogonadismo, hipoplasia genital, micropênis, criptorquidia bilateral. Clinodactilia do $5^{\circ}$ dedo das mãos. Pé chato, dedos tortos. Calça sapatos número 38. Manchas hipopigmentares segmentadas em ondas pelo corpo, 
semelhantes às presentes na hipomelanose de Ito. Traço falciforme. Devido à epilepsia toma Neuleptil desde que nasceu.

Problemas de alimentação na infância (com necessidade de técnicas especiais para a alimentação). Rápido e excessivo ganho de peso entre 1 e 6 anos de idade, com obesidade central. Hiperfagia, obsessão por comida. Distúrbios do sono. Saliva viscosa. Alto limiar para a dor. Habilidade em montar quebra-cabeças. Não tem capacidade de vomitar diminuída.

No retorno para coleta de material para estudo citogenético $(25 / 02 / 2013)$ o paciente estava com 13 anos e apresentava a estatura de 1,70 m (p95-p97) e peso 85,15 kg ( $p>97,5)$. Desenvolveu a puberdade.

Diagnosticado com apneia obstrutiva grau grave; fez a cirurgia e atualmente dorme toda a noite, com auxílio de medicamento. Desenvolveu o controle esfincteriano, utilizando fralda somente no período noturno.

Possui facilidade para decorar textos, conhece alfabeto e números, mas não consegue juntar as letras para formar palavras e pouca habilidade motora para escrever. Fala com erros de dicção. Período da manhã com acompanhamento escolar especial e período da tarde em escola normal, mas com auxílio de um profissional o tempo todo. Não houve novas ocorrências de convulsões.

Estudo do padrão de metilação para a região PWS/AS e teste de MLPA com o kit P064-B2 normais.

O emprego do array CytoSure ISCA 4x180k (OGT) mostrou uma deleção terminal do braço curto do cromossomo 8 (p23.3 - p23.1) de 7.7Mb localizada em $176464 p b$ e $7881234 p b$. Também foi detectada uma duplicação terminal do braço curto do cromossomo 12 (p13.33 - p13.31) de 8.16Mb 
localizada em 148375pb e 8309473pb, conforme o Ensembl Genome Browser (versão NCBI37/hg19).

O teste de MLPA com os kits P036-E1 e P070-B1 confirmou os achados no array Cytosure da deleção no braço curto do cromossomo 8 e duplicação no braço curto do cromossomo 12. Os genitores também foram testados com esses kits apresentando resultado normal para ambos (Figura 18).

Também se executou a hibridação in situ fluorescente com a sonda RP11-45M12 para a região deletada do cromossomo 8 (p23.2) marcada com digoxigenina (vermelho), a sonda RP11-433L7 para a região não deletada do cromossomo 8 (p22) marcada com biotina (verde), a sonda RP11-320N7 para a região duplicada do cromossomo 12 (p13.32) marcada com digoxigenina (vermelho), a sonda RP11-434C1 para a região não duplicada do cromossomo 12 (p13.2) marcada com biotina (verde). Como mostrado na Figura 19, confirmam-se as alterações detectadas no array, onde se pode observar que a região duplicada do cromossomo 12 encontra-se posicionada no braço curto do cromossomo 8, na região que está deletada.

Como o MLPA já havia descartado alguma alteração de número de cópias para as regiões subteloméricas dos braços curtos dos cromossomos 8 e 12 dos genitores, o FISH foi efetuado para investigar a presença de translocações equilibradas. Utilizando as mesmas sondas, afastou-se a ocorrência de translocações, exibindo duas marcações para o cromossomo 8 e duas marcações para o cromossomo 12 em cromossomos separados (Figuras 20 e 21). 

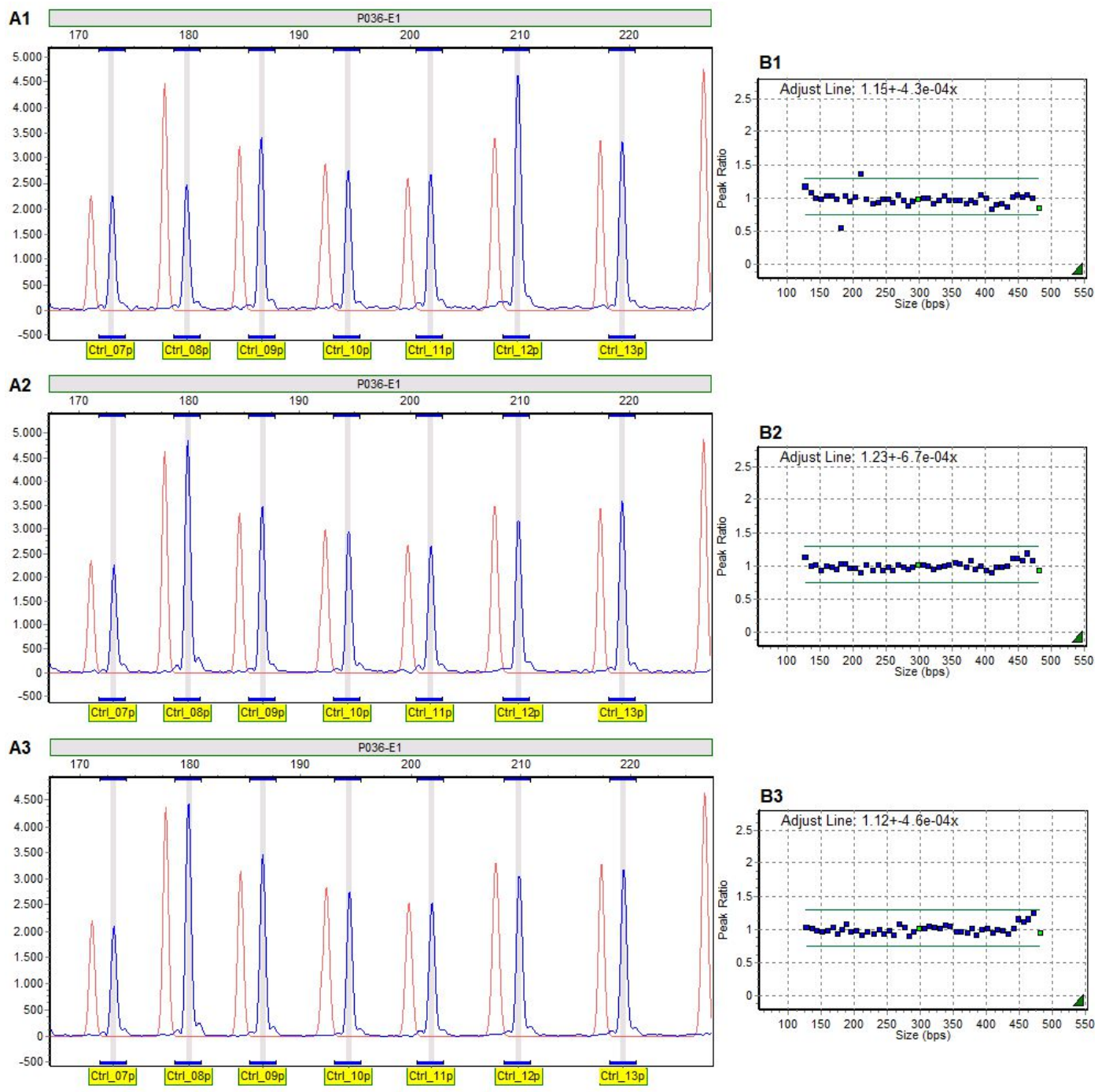

Figura 18 - Resultado do MLPA com o kit P036 do paciente 20 e genitores. A - histograma de dosagem, onde os picos em vermelho correspondem ao grupo controle, enquanto os picos em azul são relativos ao paciente. B - Quociente de dosagem das sondas específicas (em azul) no paciente em relação a um grupo controle. O intervalo é delimitado por 0.65 e 1.35 . Sondas posicionadas abaixo do limite de $\mathbf{0 . 6 5}$ indicam deleção; sondas posicionadas acima do limite de 1.35 indicam duplicação. A1 e B1 - Resultado do paciente indicando deleção da região subtelomérica do cromossomo 8 e duplicação da região subtelomérica do cromossomo 12. A2 e B2 - Resultado da mãe do paciente: normal. A3 e B3 - Resultado do pai do paciente: normal. 


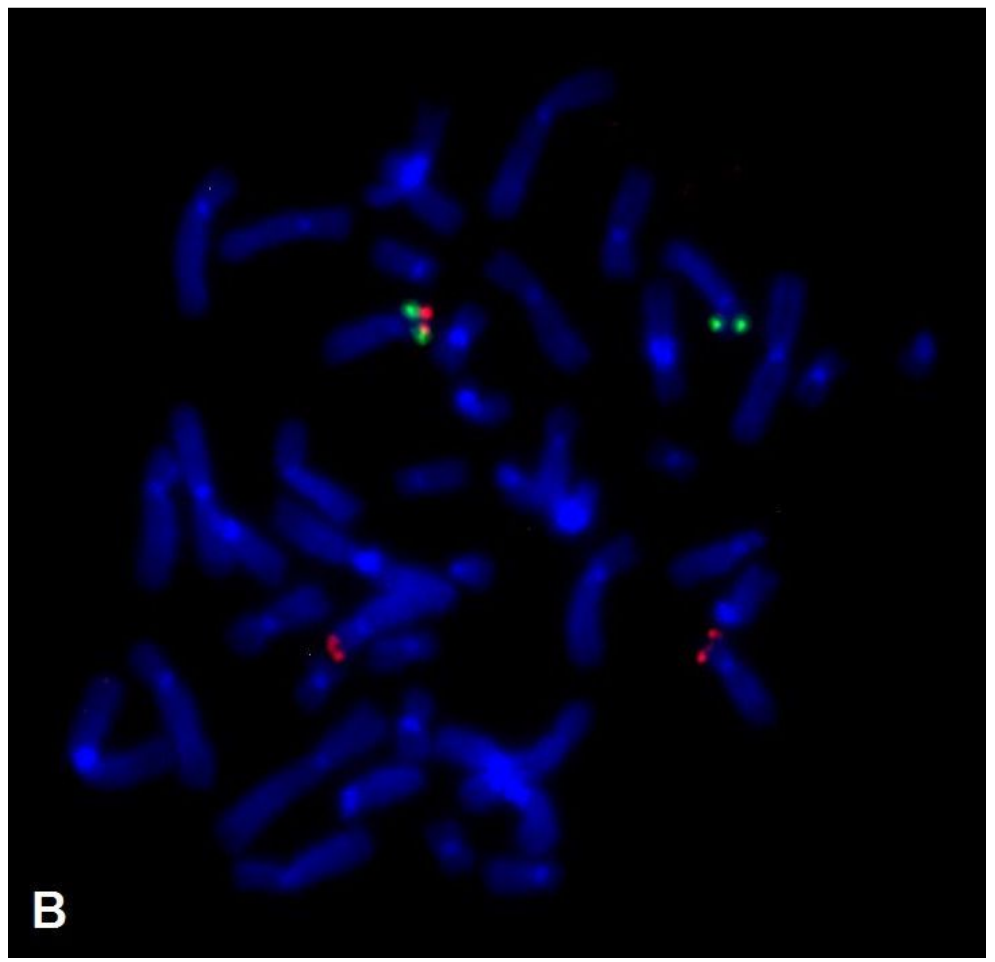

Figura 19 - FISH em metáfases do paciente 20. A - Utilizando a sonda RP11-45M12 para a região deletada do cromossomo 8 (p23.2) em vermelho e a sonda RP11-433L7 para a região não deletada do cromossomo 8 (p22) em verde. B - Utilizando a sonda RP11-433L7 para a região não deletada do cromossomo 8 (p22) em verde e a sonda RP11-320N7 para a região duplicada do cromossomo 12 (p13.32) em vermelho. 

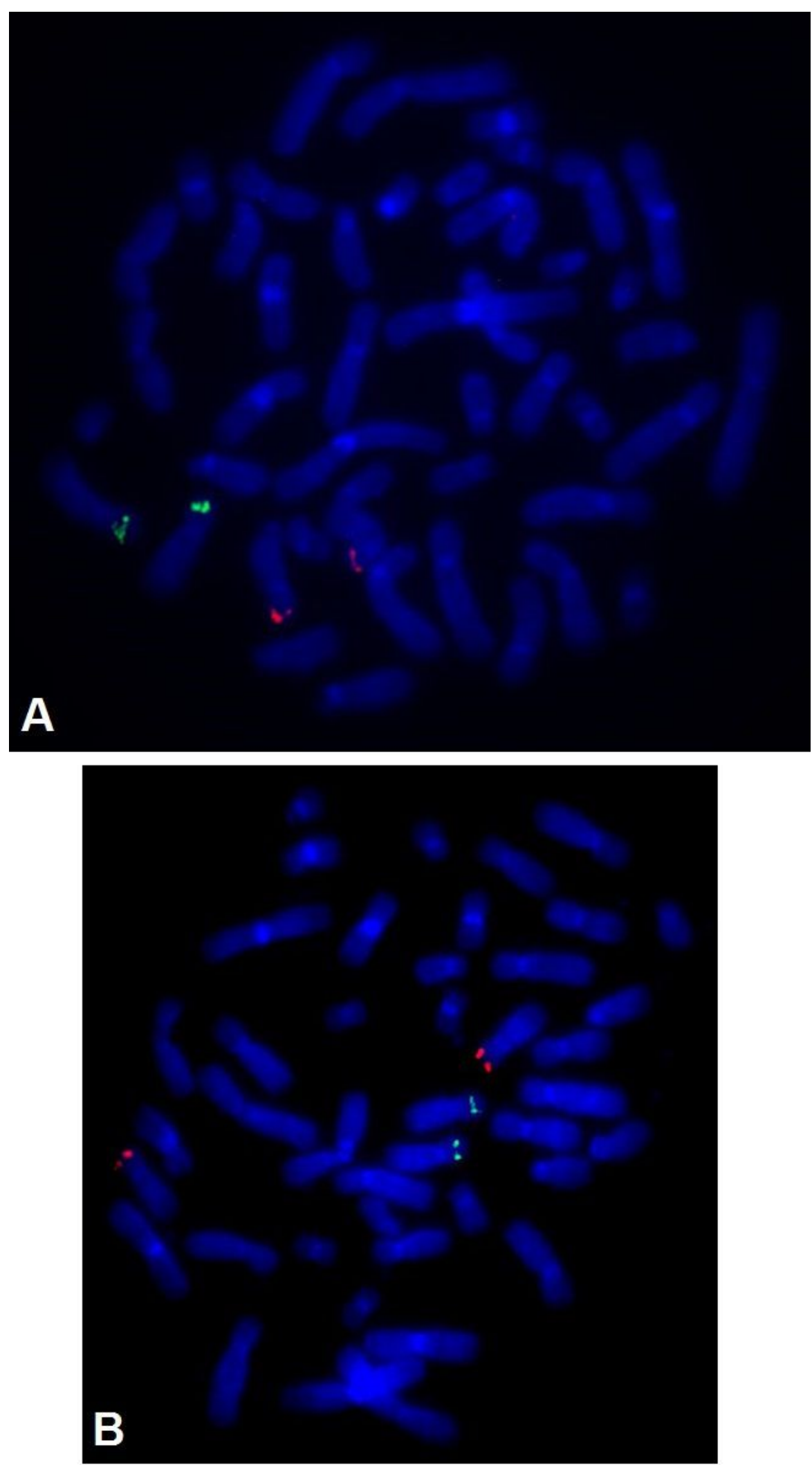

Figura 20 - FISH em metáfases da mãe (A) e pai (B) do paciente 20. Utilizando a sonda RP11-433L7 para a região não deletada no paciente do cromossomo 8 (p22) em verde e a sonda RP11-320N7 para a região duplicada no paciente do cromossomo 12 (p13.32) em vermelho. 

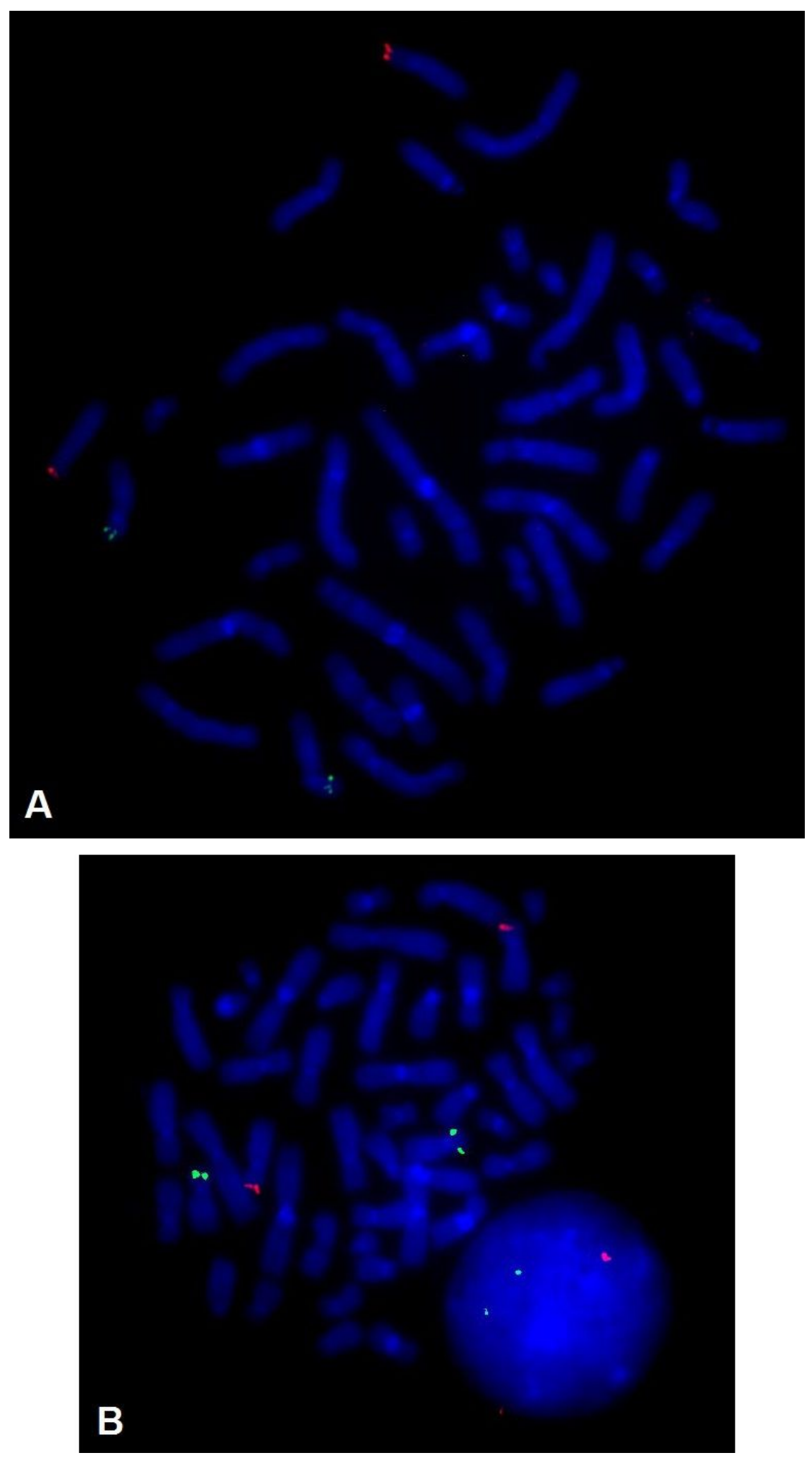

Figura 21 - FISH em metáfases da mãe (A) e pai (B) do paciente 20. Utilizando a sonda RP11-45M12 para a região deletada no paciente do cromossomo 8 (p23.2) em vermelho e a sonda RP11-434C1 para a região não duplicada no paciente do cromossomo 12 (p13.2) em verde. 
Margari et al. (2012) descreveram uma paciente com o fenótipo de anomalias do desenvolvimento neurológico, cognitivo e alterações comportamentais associadas com dismorfismo facial, anomalias do sistema nervoso central e epilepsia, portadora de uma deleção em 8p23.2p23.3 de 6.8Mb e uma duplicação em 12p13.31p13.33 de $8.4 \mathrm{Mb}$ de novo. A deleção do $8 p$ tinha o ponto de quebra proximal dentro da região REPD, um dos dois clusters de genes receptores olfatórios de 8p23.1, que tornam a região susceptível a vários rearranjos genômicos.

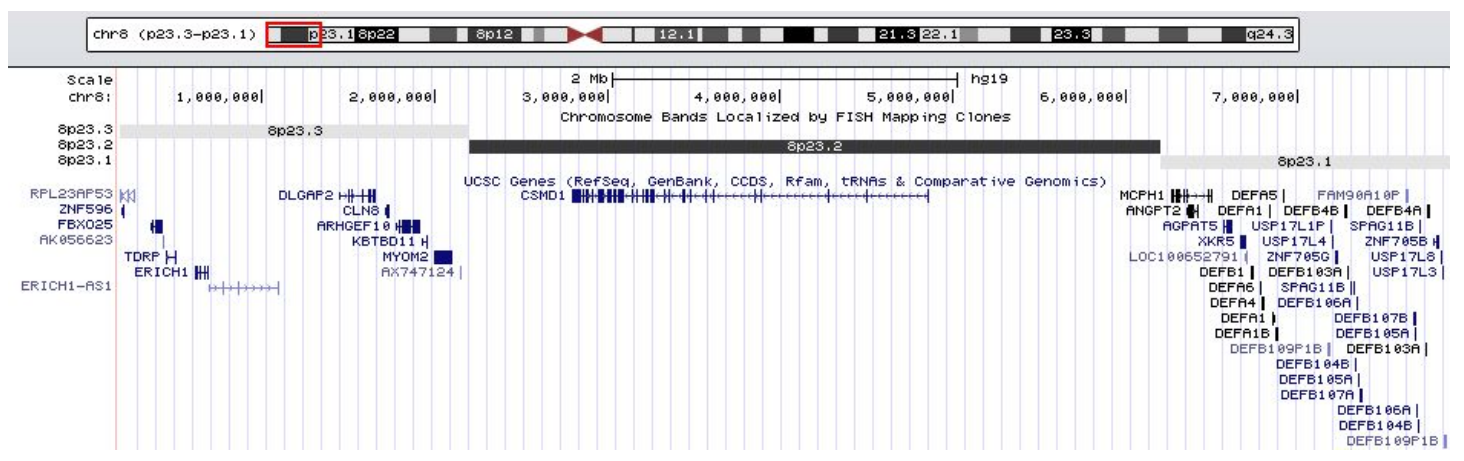

Figura 22 - llustração dos genes deletados da região 8 p23.3 - p23.1 do paciente 20 . 0 retângulo vermelho destaca a região deletada. Retirado do UCSC Genome Browser em 12/2012.

Goldlust et al. (2013) descreveram uma translocação recorrente não equilibrada causadora de uma nova síndrome associada com deficiência intelectual, macrocefalia, eczema, convulsões e obesidade. A translocação é mediada por NAHR entre $\sim 280 \mathrm{~kb}$ de duplicações segmentares dos cromossomos $8 p 23.1$ e 12p13.31, dado também reforçado pelo estudo de Ou et al. (2011). Esta translocação leva a uma duplicação de mais de 100 genes do cromossomo 12, incluindo o gene G-protein beta 3 (GNB3), que já foi identificado em estudos de associação como um candidato a gene de 
obesidade. Para confirmar esses dados geraram camundongos transgênicos portadores de uma cópia extra do haplótipo de risco do GNB3 humano, tendo como resultado machos e fêmeas $4.1-7.5 \%$ e $6.0-14.3 \%$ mais pesados, respectivamente, quando comparados a camundongos selvagens. Com qPCR detectaram uma expressão maior de GNB3 humano em todo o cérebro dos animais transgênicos. Os autores concluíram que a dosagem gênica e superexpressão de GNB3 elevou o IMC, fornecendo evidências para uma nova síndrome genética causada por uma CNV recorrente.

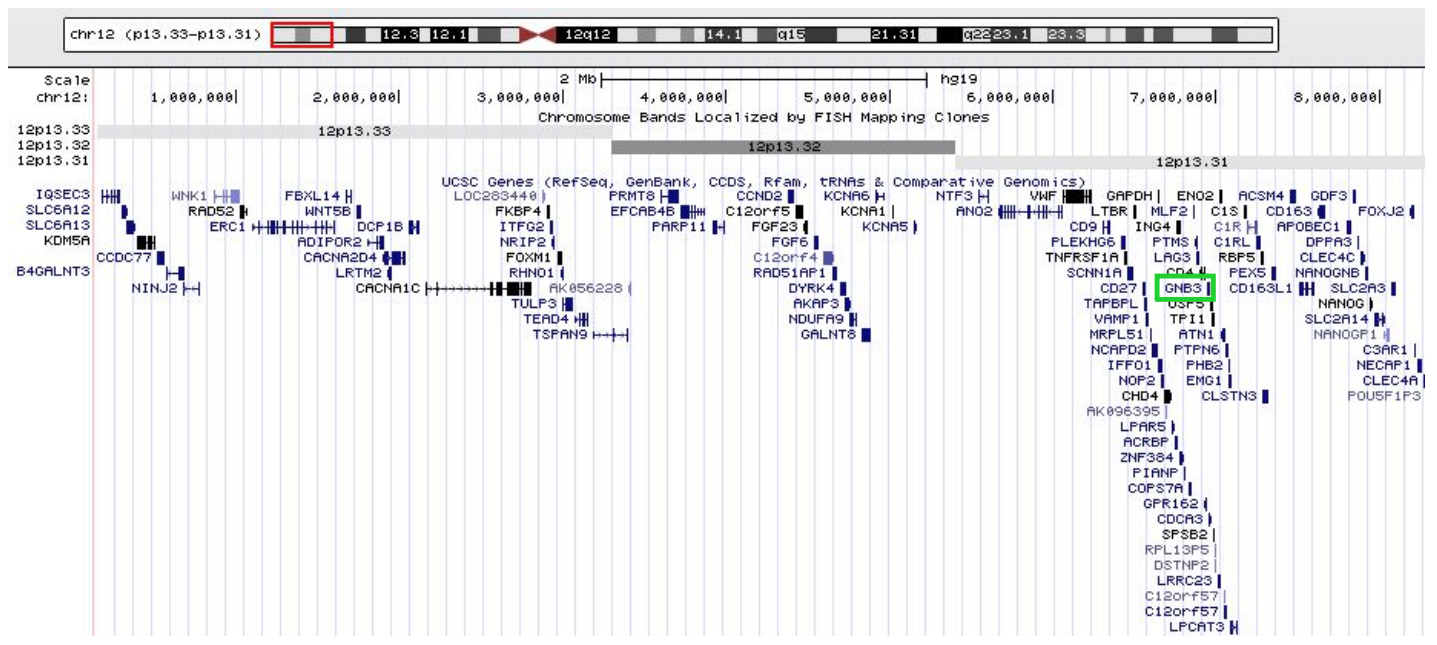

Figura 23 - llustração dos genes duplicados da região 12p13.33-p13.31 do paciente 20. 0 retângulo vermelho destaca a região duplicada. Em destaque no retângulo verde o gene GNB3. Retirado do UCSC Genome Browser em 12/2012. 


\section{Paciente 23}

P.P.R., sexo masculino, 14 anos. Mãe biológica tinha deficiência intelectual, praticamente não falava. Engravidou aos 17 anos, sendo que o pai do paciente é possivelmente seu avô materno. Mãe adotiva não tem contato com a mãe biológica. O paciente foi encaminhado ao nosso serviço com suspeita de síndrome de Prader-Willi. Parto cesáreo, peso ao nascimento $2800 \mathrm{~g}$, comprimento $46 \mathrm{~cm}$. Sucção fraca. Aos 5 dias passou por cirurgia devido a estenose anal congênita e aos 3 meses outra cirurgia devido a comunicação interventricular (persistência de canal arterial). Broncopneumonias de repetição. Sentou sem apoio aos 8 meses. Começou a andar com 2 anos. A partir dos 3 anos começou a formar frases, com auxílio de fonoaudiólogo. Sabe ler, escrever, porém não faz contas. Controle esfincteriano aos 5 anos. Faz fisioterapia. Retardo no desenvolvimento neuropsicomotor e agitação psicomotora. Episódios de taquicardia, tremores, dores pelo corpo e palidez. Uso prolongado de corticoides devido a episódios repetitivos de bronquites e bronquiolites.

Na ocasião da consulta apresentava a estatura 1,60 m (p25-p50) e peso $103,5 \mathrm{~kg}(p>97,5)$. Dismorfismos craniofaciais, com abaulamento frontal, fronte estreita. Implantação baixa de cabelos na fronte. Pescoço curto e grosso. Orelhas grandes. Sinofre, inclinação mongólica, epicanto e estrabismo convergente de ambos os olhos. Nariz pequeno com narinas antivertidas. Macrognatismo e prognatismo. Palato alto. Leve braquidactilia do $5^{\circ}$ dedo das mãos. Pés grandes (calça 41), com sobreposição dos dedos. Manchas na pele claras e escuras. Tecido celular subcutâneo escasso e musculatura normal. 
Problemas de alimentação na infância com pouco ganho de peso, apresentando um rápido e excessivo ganho de peso com 6 anos. Excessiva ingesta alimentar. Obesidade mórbida. Problemas de comportamento como acessos de violência, comportamento obsessivo/compulsivo e mentiras. Alto limiar para a dor. Não tem diminuição da capacidade de vomitar.

Exame de eletroencefalograma (EEG) normal. Ressonância magnética do crânio normal. BERA compatível com comprometimento condutivo e/ou neurossensorial.

Cariótipo normal 46,XY (realizado em outro laboratório). Estudo do padrão de metilação para a região PWS/AS normal.

O emprego do array CytoSure ISCA 4x180k (OGT) mostrou uma duplicação intersticial do braço longo do cromossomo 21 (q22.13) de 515kb localizada em 38510849pb e 39025873pb, conforme o Ensembl Genome Browser (versão NCBI37/hg19).

Para comprovar a alteração detectada no array, realizou-se a análise com qPCR, utilizando-se o gene DSCR3 para o desenho dos primers foward (CAGCTCCACGCTTCTGATG) e reverse (TCCTTCGAGGACATCTCAACTC), demonstrando a duplicação previamente observada.

A duplicação deste paciente está inserida na região crítica da síndrome de Down (DSCR), localizada em 21q22, com aproximadamente 5,4Mb de tamanho (Ronan et al., 2009). Duplicações parciais do cromossomo 21 que abrangem esta região levam ao desenvolvimento do fenótipo desta síndrome. Diversas características fenotípicas presentes em pacientes com síndrome de Down também aparecem em nosso paciente, como inclinação mongólica dos olhos, epicanto e estrabismo, comunicação interventricular, perda auditiva, 
deficiência intelectual e tendência à obesidade. Não se tem o exato conhecimento de qual(is) gene(s) são essenciais para o desenvolvimento do fenótipo, mas Arron et al. (2006) concluíram que o aumento da dosagem de DSCR1 e DYRK1A levam a muitas das características da síndrome de Down.

Kosaki et al. (2005) sugeriram que duplicações dos genes DSCAM e COL6A1 no cromossomo 21 podem contribuir para o defeito cardíaco em geral, porém não se encontram em cópia extra no paciente estudado. Já Ronan et al. (2009) descrevem em seu trabalho uma mãe, seu feto e sua filha de 8 anos portadores de características fenotípicas da síndrome de Down, porém sem defeitos cardíacos. Apresentavam uma duplicação parcial do cromossomo 21 que incluía o gene $D Y R K 1$, mas não DSCR1 e DSCAM e relataram trabalhos anteriores que ligavam os genes DSCR1 e DSCAM a defeitos cardíacos na síndrome de Down (Arron et al., 2006).

Um produto gênico da DSCR, a proteína Dyrk1A, provavelmente contribui para a neuropatologia da doença de Alzheimer-like, compromete a neurogênese e também está envolvida com apoptose, mas sua superexpressão não poderia explicar todos os sintomas da síndrome de Down (Park et al., 2010). Tem sido proposto que o gene DYRK1A está associado com microcefalia e retardo mental, dada a sua localização na região de sobreposição mínima observada em pacientes com monossomia parcial do cromossomo 21. A superexpressão do DYRK1A em camundongos leva ao aumento do peso do cérebro, defeitos na memória e aprendizado, atraso do neurodesenvolvimento, hiperatividade e anomalias motoras. Já em pacientes com a síndrome de Down, a proteína Dyrk1A é superexpressa no cérebro, que é caracterizado por microcefalia, reduzidos neurônios corticais e sinapses 
anormais (Møller et al., 2008). O gene DSCR3 é expresso no cérebro, coração, pulmão, fígado, pâncreas e placenta. A proteína codificada pelo gene KCNJ6 é uma proteína integral de membrana que permite um maior fluxo de potássio para dentro da célula e pode estar envolvida na regulação da secreção de insulina.

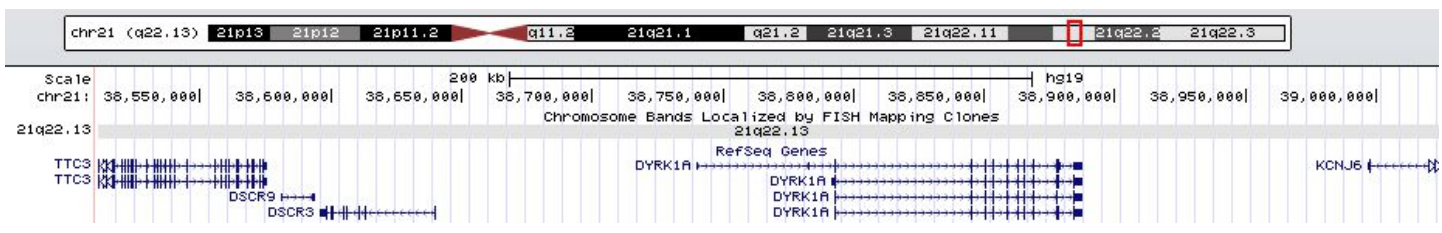

Figura 24 - Ilustração dos genes duplicados da região $21 q 22.13$ do paciente 23 . 0 retângulo vermelho destaca a região duplicada. Retirado do UCSC Genome Browser em 11/2012.

A tabela 3 apresenta resumidamente genes e/ou regiões previamente descritas na literatura associadas a fenótipos encontrados nos pacientes com trissomias ou monossomias do cromossomo 21, demonstrando a importância de genes sensíveis à dosagem no desenvolvimento das características clínicas. 
Tabela 3 - Associação de genes e/ou regiões a fenótipos presentes nos pacientes com trissomias ou monossomias do cromossomo 21 descritos na literatura.

\begin{tabular}{|c|c|c|}
\hline Fenótipo & Gene(s)/Região & Referências \\
\hline \multirow[t]{3}{*}{$\begin{array}{l}\text { Deficiência intelectual/ } \\
\text { Atraso no desenvolvimento }\end{array}$} & $\begin{array}{l}\text { KCNJ6, DSCR4, } \\
\text { KCNJ15 }\end{array}$ & Lyle et al. (2009) \\
\hline & DYRK1A, DSCAM & Lana-Elola et al. (2011) \\
\hline & ITSN1 & Roberson et al. (2011) \\
\hline \multirow[t]{4}{*}{ Defeitos cardíacos } & DSCAM & $\begin{array}{l}\text { Kosaki et al. (2005); Korbel } \\
\text { et al. (2009) }\end{array}$ \\
\hline & DSCR1 & Arron et al. (2006) \\
\hline & $\begin{array}{l}\text { KCNE1, RCAN1, CLIC6, } \\
\text { RUNX1 }\end{array}$ & Roberson et al. (2011) \\
\hline & COL6A1, SLC19A1 & Lana-Elola et al. (2011) \\
\hline $\begin{array}{l}\text { Dismorfismos faciais e } \\
\text { anormalidades do crânio e } \\
\text { cérebro }\end{array}$ & SIM2 & Chen et al. (2001) \\
\hline Doença de Hirschsprung & DSCAM & $\begin{array}{l}\text { Korbel et al. (2009); Jannot } \\
\text { et al. (2013) }\end{array}$ \\
\hline Doença de Alzheimer & $A P P$ & $\begin{array}{l}\text { Deutsch et al. (2005); } \\
\text { Korbel et al. (2009) }\end{array}$ \\
\hline $\begin{array}{l}\text { Leucemia megacariocítica } \\
\text { aguda/deficiência } \\
\text { mieloproliferativa transiente }\end{array}$ & RUNX1, ERG, ETS & Korbel et al. (2009) \\
\hline $\begin{array}{l}\text { Estenose duodenal/ Ânus } \\
\text { imperfurado }\end{array}$ & $21 q 21.11-q 22.3$ & Korbel et al. (2009) \\
\hline
\end{tabular}




\section{Paciente 31}

B. S. F., sexo feminino, 7 anos e 7 meses. Pai com 47 e mãe com 48 anos. Nega consanguinidade. Sem histórico de abortos. Um irmão de 13 anos saudável. Na família da avó materna, todos são obesos e hipertensos. A paciente foi encaminhada ao nosso serviço com suspeita de síndrome de Prader-Willi. A gestação durou 9 meses. A mãe vomitou muito durante a gravidez, movimentos fetais aumentados em relação ao irmão. Parto cesáreo, peso ao nascimento $2790 \mathrm{~g}$, comprimento $45 \mathrm{~cm}$. Chorou, suç̧ão normal. Hipotonia neonatal. Firmou a cabeça com 4 meses. Sentou sem apoio aos 7 meses. Começou a andar com 1 ano. Começou a formar frases a partir de 2 anos. Entrou na escola com 1 ano e 6 meses. Dificuldades de aprendizagem: escreve letras e sílabas, sabe fazer contas (soma e subtração). Problemas de articulação da fala. Em 2010 iniciou tratamento com fonoaudiólogo, com bons resultados.

$\mathrm{Na}$ ocasião da consulta apresentava a estatura 1,24 m (p25-p50), peso $50 \mathrm{~kg}(p>97,5)$ e perímetro cefálico $57 \mathrm{~cm}(p>97,5)$. Leve abaulamento frontal, fronte estreita. Implantação alta de cabelos na fronte. Pescoço curto. Orelhas grandes com lóbulo solto. Avaliação audiológica em 2011: presença de acometimento condutivo leve na orelha direita e condutivo com uma frequência mista leve/moderada na orelha esquerda. Astigmatismo no olho esquerdo (3 graus) e direito (1,25 graus). Nariz em sela, narinas pouco antivertidas. Macrognatismo, leve macrostomia. Lábio inferior grosso. Filtro bem desenhado. Dedos levemente grossos, afilados nas pontas. Genitais normais. 
Obesidade central antes de completar um ano de idade. Compulsão alimentar. Problemas de comportamento como teimosia e acessos de violência. Não tem diminuição da capacidade de vomitar.

Estudo do padrão de metilação para a região PWS/AS, teste de MLPA com os kits P064-B2, P036-E1, P070-B1 normais.

O emprego do array CytoSure ISCA 4x180k (OGT) mostrou uma deleção intersticial do braço curto do cromossomo 20 (p12.1) de 628,7kb localizada em 15345658pb e 15974369pb, conforme o Ensembl Genome Browser (versão NCBI37/hg19), de maneira que parte do gene MACROD2 (C20orf133) apresentava apenas uma cópia no paciente.

Para comprovar a alteração detectada no array, realizou-se a análise com qPCR, utilizando-se o gene MACROD2 para o desenho dos primers foward (TTTTGCCTCTAGGTGGATCG) e reverse (CGGCTCCACTTCTTCCATC), demonstrando a deleção previamente observada. Os genitores também foram analisados, e ficou evidenciado que a deleção foi herdada do pai.

O gene MACROD2 apresenta 2,06Mb de tamanho, contém 17 exons e é altamente conservado evolutivamente. É expresso no cérebro fetal e adulto, timo, músculo esquelético, fígado, pâncreas, próstata, pulmão e rim. Dentro de seu íntron 3 possui a sequência do gene FRLT3. MACROD2 tem função enzimática e está envolvido no reparo de DNA (Jankevicius et al., 2013). Maas et al. (2007) descreveram uma paciente com deleção de 250kb no exon 5 do gene MACROD2 (Figura 25) e fenótipo da síndrome de Kabuki. Posteriormente, um estudo com 43 pacientes portadores da síndrome de 
Kabuki não conseguiu dar suporte à hipótese de Maas et al. (Kuniba et al., 2008).

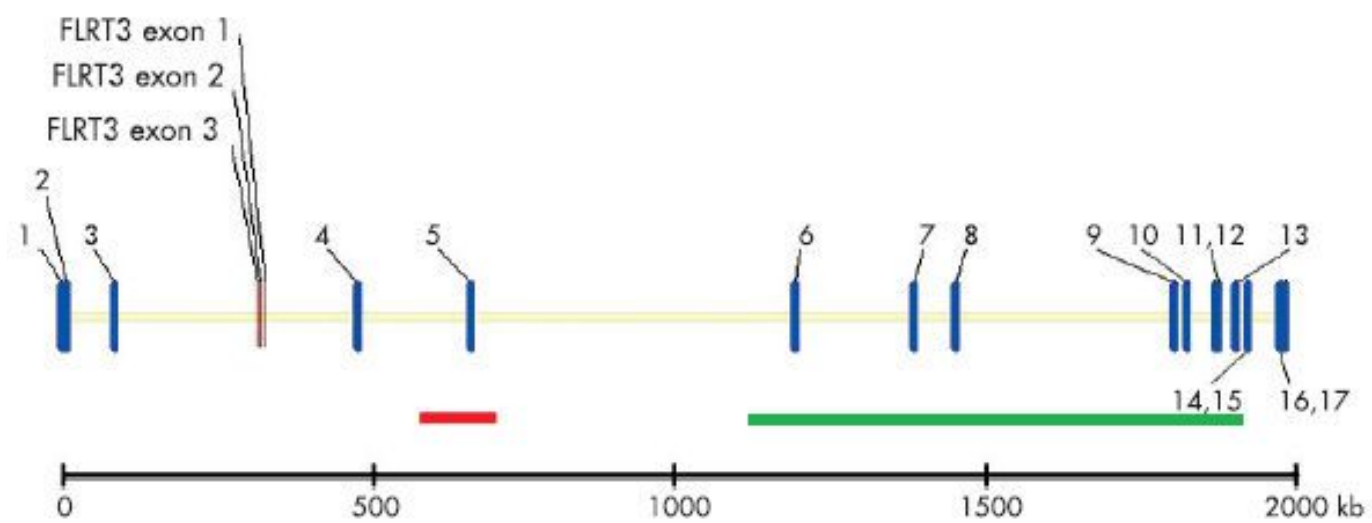

Figura 25 - Esquema dos exons e íntrons dos genes MACROD2 e FLRT3. A linha vermelha indica a deleção de $250 \mathrm{~kb}$ descrita por Maas et al. (2007). A linha verde indica a deleção de $628,7 \mathrm{~kb}$ encontrada em nosso paciente (figura modificada de Maas et al., 2007).

Buscas no DECIPHER retornaram como resultado dois pacientes com deleção no gene MACROD2, mas sem sobreposição com a deleção de nosso paciente, que apresentam obesidade. Além da obesidade, um paciente (249098) apresenta deficiência intelectual, microcefalia e ataxia do tronco; o segundo paciente (258431) apresenta hipopituitarismo anterior, autismo e deficiência intelectual. Um outro paciente (250879), também sem sobreposição à deleção, apresenta hipertelorismo, anormalidades na face, deficiência auditiva condutiva, atraso no desenvolvimento da fala e linguagem e deficiência intelectual, sendo que as quatro últimas características estão presentes em nosso paciente, e sua deleção foi herdada de um genitor fenotipicamente normal Diversos outros pacientes com deleções neste gene apresentam deficiência intelectual. (Figura 26). 


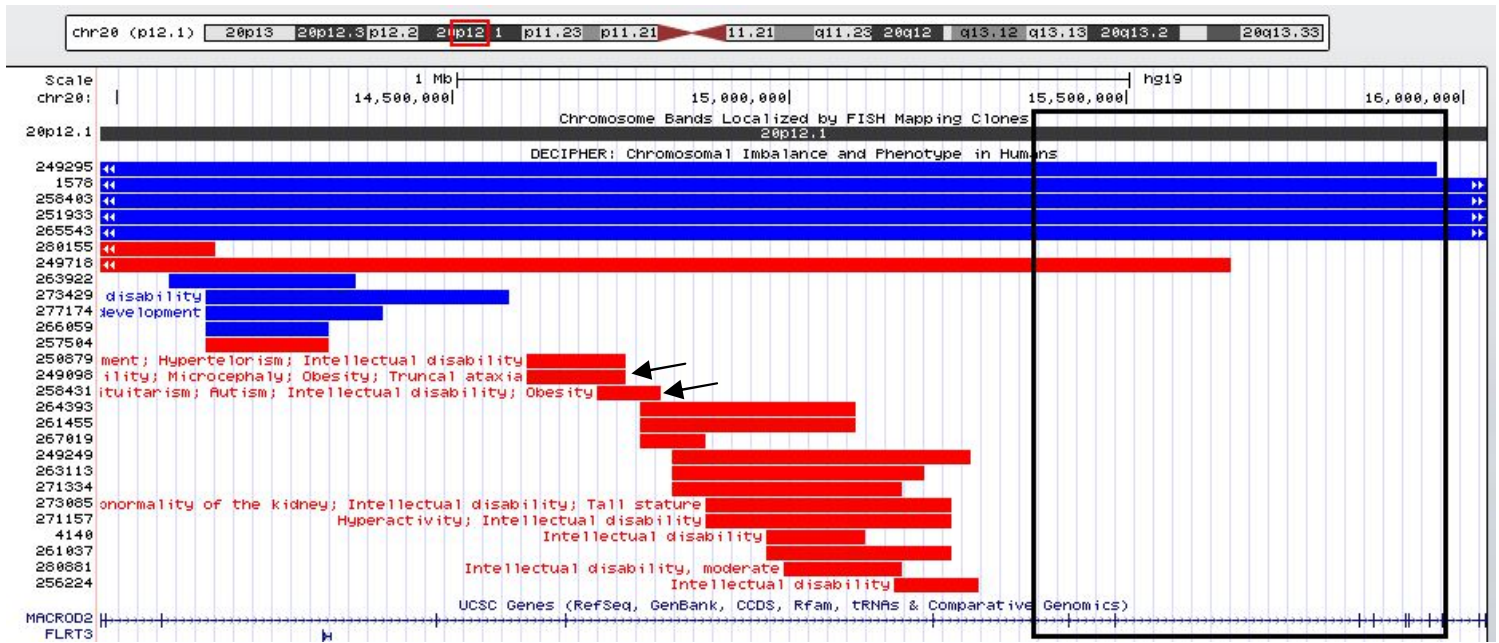

Figura 26 - Pacientes com alterações genômicas que ocorrem no gene MACROD2. As setas pretas indicam os pacientes relatados no DECIPHER com fenótipo de obesidade. A área demarcada pelo retângulo preto é a área da alteração da paciente 31. Imagem retirada do UCSC Genome Browser em 12/2013.

Na tabela 4 é apresentado um resumo das variações de número de cópias encontradas nos pacientes.

Na tabela 5, um resumo dos dados antropométricos. 


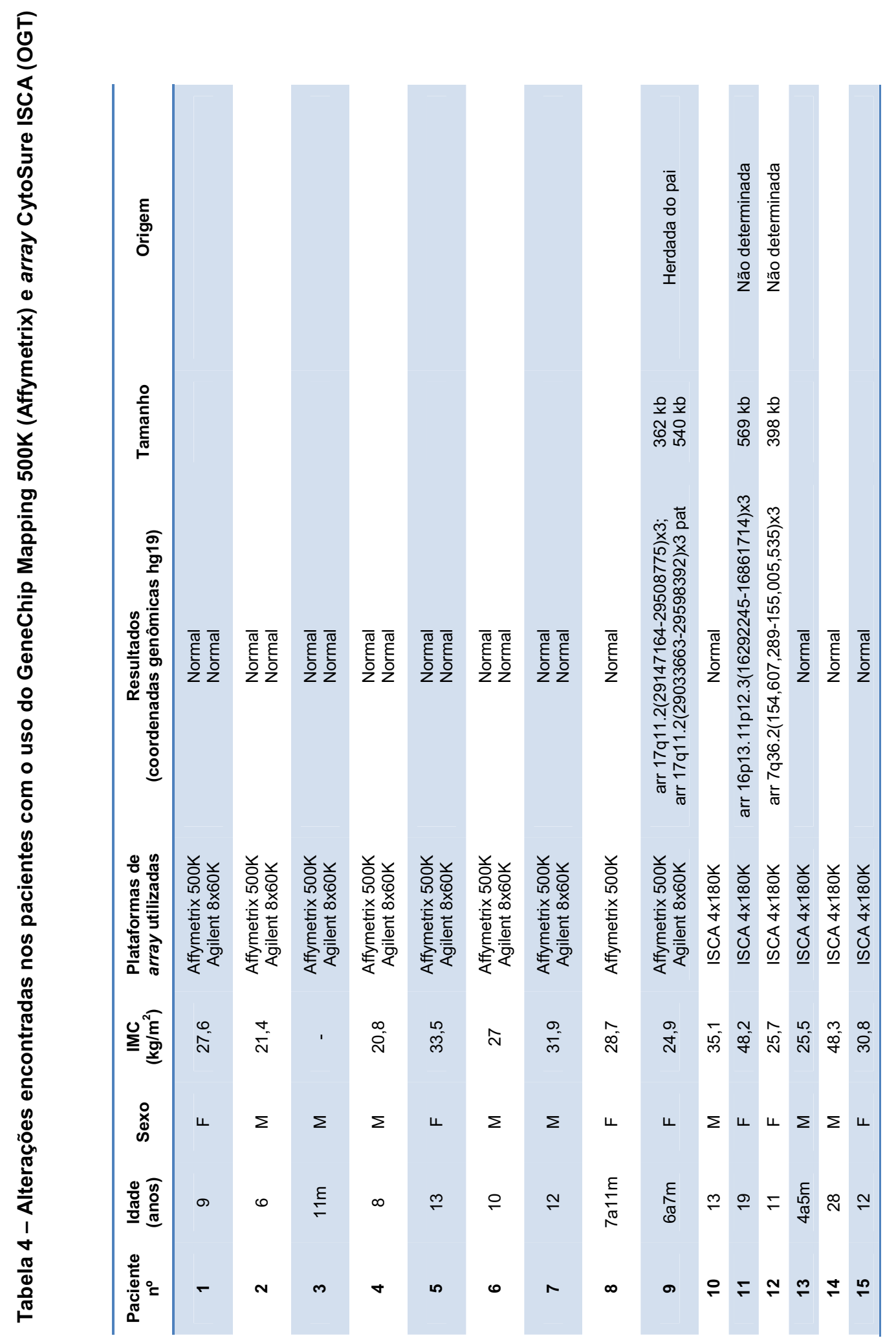




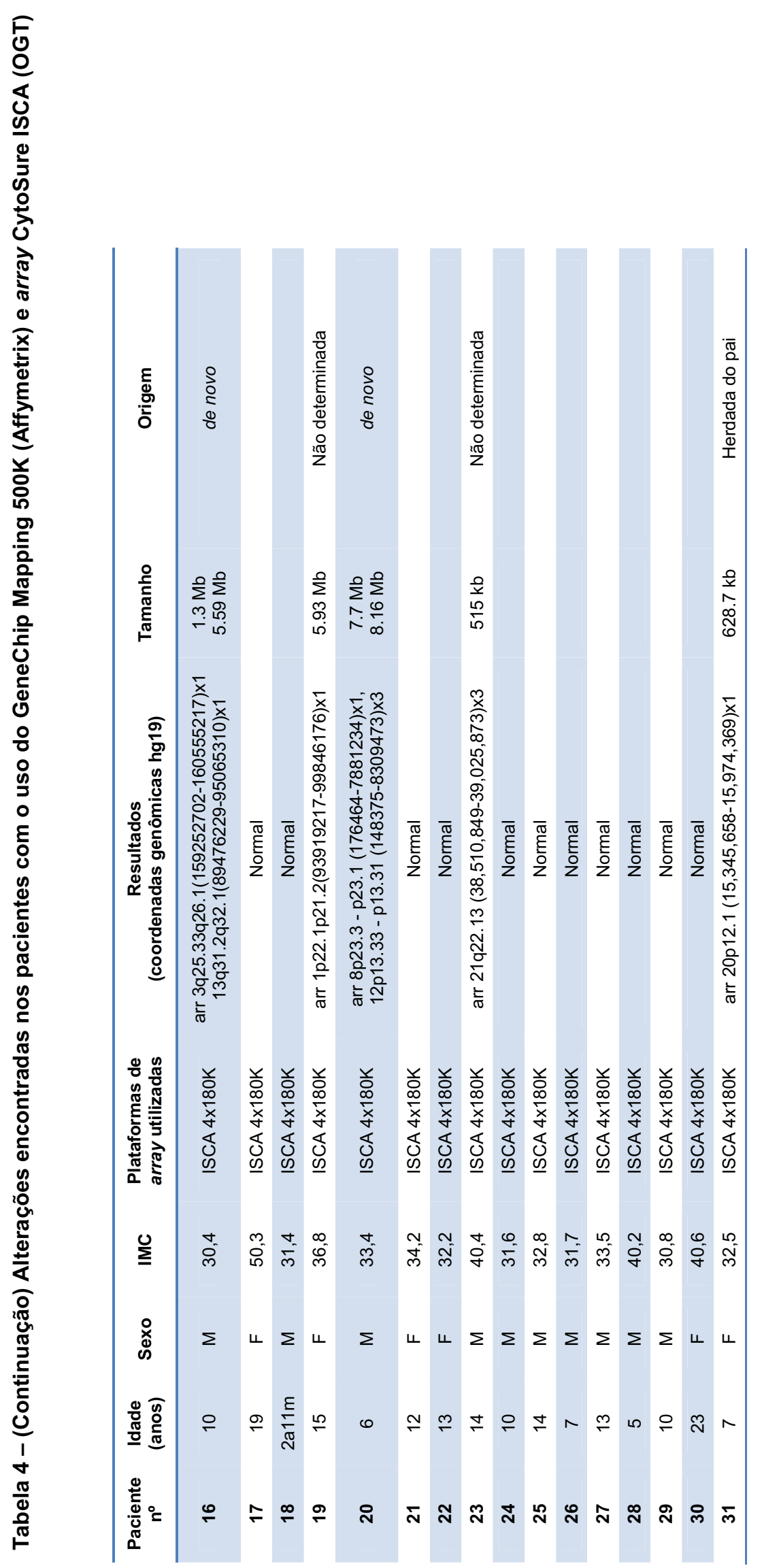


Tabela 5 - Dados antropométricos dos pacientes estudados

\begin{tabular}{|c|c|c|c|c|c|c|c|c|c|}
\hline \multirow{2}{*}{ Paciente } & \multirow{2}{*}{ Sexo } & \multirow{2}{*}{ Idade } & \multicolumn{2}{|c|}{ Altura } & \multicolumn{2}{|c|}{ Peso } & \multirow{2}{*}{$\frac{\text { IMC }}{\left(\mathrm{kg} / \mathrm{m}^{2}\right)}$} & \multicolumn{2}{|c|}{ Perímetro Cefálico } \\
\hline & & & (m) & percentil & $(\mathrm{Kg})$ & percentil & & (cm) & percentil \\
\hline 1 & $F$ & $9 a$ & 1,38 & p75-p90 & 52,5 & $p>97,5$ & 27,57 & - & - \\
\hline 2 & M & $6 a$ & 1,21 & p90-p97,5 & 31,4 & $>p 97,5$ & 21,45 & 53,5 & p90-p97,5 \\
\hline 3 & M & $11 \mathrm{~m}$ & 0,76 & p50-p75 & 11,4 & p75-p90 & 19,74 & 44 & p10-p25 \\
\hline 4 & M & $8 a$ & 1,42 & $p>97,5$ & 42 & $p>97,5$ & 20,83 & 57 & $>p 97,5$ \\
\hline 5 & $\mathrm{~F}$ & $13 a$ & 1,6 & p75-p90 & 85,5 & $p>97,5$ & 33,40 & 58 & $>p 97,5$ \\
\hline 6 & M & $10 a$ & 1,47 & p90-p97,5 & 58,4 & $p>97,5$ & 27,03 & 55 & p90-p97,5 \\
\hline 7 & M & $12 a$ & 1,47 & p50-p75 & 69 & $p>97,5$ & 31,93 & 52 & p25-p50 \\
\hline 8 & $\mathrm{~F}$ & $\begin{array}{c}7 a \\
11 m\end{array}$ & 1,15 & $\mathrm{p} 2,5-\mathrm{p} 10$ & 38 & $p>97,5$ & 28,73 & 47,5 & $<p 10$ \\
\hline 9 & $\mathrm{~F}$ & $\begin{array}{l}6 a \\
7 m\end{array}$ & 1,16 & p25-p50 & 33,5 & $p>97,5$ & 24,90 & 50,5 & p50-p75 \\
\hline 10 & M & $13 a$ & 1,62 & p75-p90 & 92 & $p>97,5$ & 35,06 & 55 & p75-p90 \\
\hline 11 & $\mathrm{~F}$ & $19 a$ & 1,49 & $p<2,5$ & 107 & $>$ p97 & 48,20 & 59 & >p98 \\
\hline 12 & $\mathrm{~F}$ & $11 a$ & 1,45 & p2,5-p10 & 54,1 & p90-p95 & 25,73 & 49,5 & p10 \\
\hline 13 & M & $\begin{array}{l}4 a \\
5 m\end{array}$ & 1 & p10 & 25,5 & $>$ p97,5 & 25,50 & 55,5 & $>$ p97,5 \\
\hline 14 & $M$ & $28 a$ & 1,82 & p50-p75 & 160 & >p95 & 48,30 & 61 & $>$ p97 \\
\hline 15 & $F$ & $12 a$ & 1,57 & p75-p90 & 75,9 & $>p 97,5$ & 30,79 & 57,5 & $>$ p97,5 \\
\hline 16 & M & $10 a$ & 1,23 & p2,5-p10 & 46 & p95-p97 & 30,41 & 54 & p75-p90 \\
\hline 17 & $\mathrm{~F}$ & $19 a$ & 1,65 & p50-p75 & 137 & $p>97,5$ & 50,32 & 57 & p90-p97,5 \\
\hline 18 & M & $\begin{array}{c}3 a \\
11 m\end{array}$ & 0,9 & p2,5-p10 & 25,4 & $p>97,5$ & 31,36 & 50 & p50-p75 \\
\hline 19 & $\mathrm{~F}$ & $15 a$ & 1,62 & p50-p75 & 97,3 & $p>97,5$ & 37,08 & 59 & $>p 97,5$ \\
\hline 20 & M & $6 a$ & 1,31 & $>p 97,5$ & 57,4 & $p>97,5$ & 33,45 & 55 & $>p 97,5$ \\
\hline 21 & $\mathrm{~F}$ & $12 a$ & 1,67 & $>p 97,5$ & 95,4 & $p>97,5$ & 34,21 & 56 & $>p 97,5$ \\
\hline 22 & $\mathrm{~F}$ & $13 a$ & 1,435 & $\mathrm{p} 2,5-\mathrm{p} 10$ & 65,8 & p90-p95 & 31,95 & 55 & $>$ p90 \\
\hline 23 & $M$ & $14 a$ & 1,6 & p25-p50 & 103,5 & $p>97,5$ & 40,43 & - & - \\
\hline 24 & M & $11 a$ & 1,36 & p10-p25 & 58,4 & $p>97,5$ & 31,57 & 56 & $>$ p97,5 \\
\hline 25 & $M$ & $14 a$ & 1,59 & p25-p50 & 83 & $p>97,5$ & 32,83 & 57 & $>$ p95 \\
\hline 26 & M & $7 a$ & 1,36 & $>$ p97,5 & 58,6 & $p>97,5$ & 31,68 & 59 & $>$ p97,5 \\
\hline 27 & $\mathrm{M}$ & $13 a$ & 1,52 & p25-p50 & 77,5 & $p>97,5$ & 33,54 & 55 & p75-p90 \\
\hline 28 & M & $\begin{array}{c}5 a \\
9 m\end{array}$ & 1,1 & p10-p25 & 48,6 & $p>97,5$ & 40,17 & 54 & $>p 97,5$ \\
\hline 29 & $\mathrm{M}$ & $10 a$ & 1,5 & p95-p97 & 68 & $p>97,5$ & 30,22 & 53 & p75 \\
\hline 30 & $\mathrm{~F}$ & $23 a$ & 1,48 & p2,5-p10 & 89 & p85-p90 & 40,63 & 51,5 & $p<2,5$ \\
\hline 31 & $\mathrm{~F}$ & $\begin{array}{l}7 \mathrm{a} \\
7 \mathrm{~m} \\
\end{array}$ & 1,24 & p25-p50 & 50 & $p>97,5$ & 32,52 & 57 & $>p 97,5$ \\
\hline
\end{tabular}


Figura 27: Fotos dos pacientes estudados que apresentaram alterações no genoma
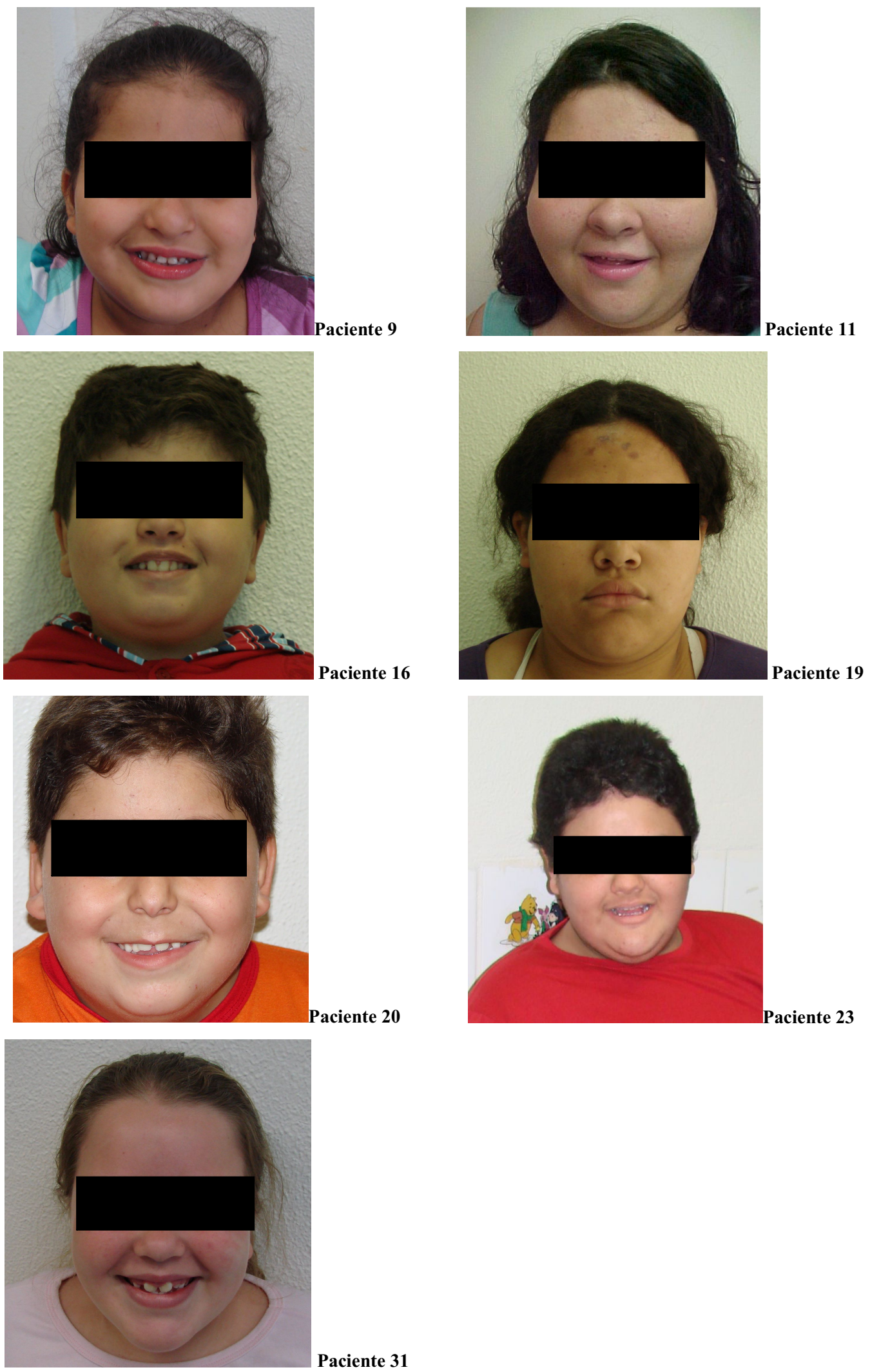


\section{Discussão}

O nosso laboratório é centro de referência no diagnóstico da síndrome de Prader-Willi (PWS), a forma sindrômica mais comum de obesidade. Graças à condição de ser um grupo de referência em todo o Brasil, recebemos um grande número de pacientes, muitos dos quais permanecem sem diagnóstico após a suspeita diagnóstica de síndrome de Prader-Willi ter sido afastada pelo teste genético específico. Este fato tornou viável a elaboração de projetos de pesquisa em pacientes que apresentam atraso do DNPM e/ou dificuldade de aprendizado, distúrbios de comportamento, obesidade e/ou hiperfagia como características principais, visando à localização de genes envolvidos com obesidade, e para o estabelecimento de diagnósticos de pacientes. Dentre esses pacientes selecionamos para o estudo com array-CGH aqueles que apresentavam também algum tipo de malformação como macrocefalia, braquicefalia, fronte estreita, sinofre, epicanto, palato alto, extremidades curtas, clinodactilia de $5^{\circ}$ dedo das mãos e criptorquidia.

A associação entre distúrbios de comportamento com obesidade e/ou hiperfagia foi inicialmente relatada para a síndrome de Prader-Willi. Anteriormente, já havíamos descrito a deleção 6q16.2, incluindo o gene SIM1, em um paciente com agressividade (Varela et al. 2006), um paciente com síndrome da deleção 22q11.2 associada com agressividade (D’Angelo et al. 2007), e três pacientes com síndrome de Smith-Magenis na qual ocorre um padrão específico de comportamento auto-agressivo. Além disso, comportamentos de (auto) agressão são frequentes em pacientes com a monossomia 1p36 e estão em alguns casos associados com obesidade e hiperfagia. 
Mais de vinte e cinco formas sindrômicas de obesidade já foram identificadas e o estudo genômico por microarray tem sido eficaz na detecção de alterações genéticas em pacientes com deficiência intelectual e malformações congênitas. Vários casos de "novas síndromes" foram encontrados, sugerindo que elas são mais comuns do que se pensava e coletivamente são susceptíveis de ser uma das principais causas de deficiência intelectual. $O$ emprego desta técnica revelou o potencial para fazer diagnósticos genéticos que não eram evidentes na apresentação clínica dos pacientes detectando as síndromes conhecidas que apresentam variação no número de cópias, assim como novas síndromes (Cooper et al., 2011).

As alterações levando a ganho e perda de pequenas partes do genoma podem ser detectadas por array, assim como translocações não equilibradas e aneuplodias, porém alterações que não resultam em variação no número de cópias, como as translocações equilibradas não são reveladas por essa técnica.

Em pesquisas anteriores já havíamos relatado várias alterações patogênicas no número de cópias do DNA em uma proporção de pacientes com características clínicas e comportamentais associadas à obesidade sem diagnóstico de PWS. As regiões genômicas identificadas foram: 1p, 2p, 3p, 6q16, 7q22.1-22.3, 11q, 12q15-q21.1, 14q11.2, 17p11.2, 22q11.2, Xp22.13p22.12 e Xq (D’Angelo et al., 2006; Krepischi-Santos et al., 2006; Varela et al., 2006; D'Angelo et al., 2007; D'Angelo et al., 2010; Kohl,I Tese de Doutorado,2010).

$\mathrm{Na}$ presente amostra de 31 pacientes com obesidade e/ou hiperfagia associada a atraso do desenvolvimento neuropsicomotor, dificuldades de 
aprendizagem, distúrbios de comportamento e outras características clínicas identificamos alterações de CNVs em 8 pacientes, o que corresponde a 25,8\% da amostra estudada. Dentre essas alterações, a duplicação 16p13.11p12.3 foi descrita como provavelmente benigna.

As alterações encontradas foram: deleção 1p22.1p21.2; deleção 3q25.33q26.1 e deleção 13q31.2q32.1; duplicação 7q36.2; deleção 8p23.3p23.1 e duplicação 12p13.33p13.31; duplicação 16p13.11p12.3; duplicação 17q11.2; deleção 20p12.1; duplicação 21q22.13.

Algumas dessas alterações estão localizadas em regiões de síndromes descritas tendo a obesidade como uma de suas principais características, como relatado para a microdeleção de 1p21.3, as duplicações do cromossomo 21 e a duplicação do gene GNB3 (cromossomo 12p13.31) que mostram pacientes com tendência a desenvolver a obesidade ou já obesos, embora poucos casos foram encontrados na literatura. Tanto a deleção de 1 p21.3 quanto a duplicação de 12p13.31, relacionada ao rearranjo genômico da translocação $(8 ; 12)$, possuem em torno de 10 pacientes anteriormente descritos para cada síndrome.

Nosso estudo permitiu a detecção de formas sindrômicas já descritas na literatura. Da mesma maneira, também possibilitou detectar novas CNVs que podem vir a se tornar síndromes após a discussão na literatura de outros casos. As alterações restantes não fazem parte de síndromes relatadas.

A duplicação em 17q11.2 não está relacionada a síndromes conhecidas, apesar de sobrepor-se ao gene NF1 que quando mutado ou deletado causa a Neurofibromatose tipo 1, e ser uma região rica em duplicações segmentares, predispondo a ocorrência de vários pacientes com CNVs nesta região. Da 
mesma forma, a duplicação em 16p13.11p12.3 também é devido à presença de duplicações segmentares por toda sua extensão. O cromossomo 16 é rico em low copy repeats o que explica os vários pacientes com desequilíbrios genômicos mapeados neste cromossomo, principalmente na banda 16p11.2.

A região da duplicação de 7q36.2 não apresenta nenhuma síndrome descrita, apesar de aproximadamente 70 pacientes descritos no DECIPHER e ISCA possuírem deleções ou duplicações nessa região. Por outro lado, o gene DPP6 presente nessa região está associado a diversas doenças, como esclerose lateral amiotrófica e autismo.

A deleção do cromossomo 3q25.33q26.1 tem sobreposição com deleções de apenas 3 pacientes descritos no DECIPHER, sendo que apresentam poucas características fenotípicas similares. Dois trabalhos, citando um total de 26 pacientes, fizeram a correlação entre diversas deleções parciais do cromossomo 13 e o fenótipo, refinando a menor região ligada à baixa estatura, porém sem descrever nenhuma síndrome justaposta à região q31.2q32.1 do cromossomo 13.

A deleção em 20p12.1 que abrange o gene MACROD2 inicialmente foi associada com a síndrome de Kabuki, mas estudos subsequentes com 43 pacientes portadores desta síndrome não deram suporte a essa hipótese.

Nas CNVs identificadas foram encontrados genes já descritos como associados à obesidade (PTBP2, DPYD, MIR137, GNB3 e PPM1L) ou possivelmente envolvidos com este fenótipo (HTR5A e KCNJ6).

Os genes RNF135, NF1, DPP6, GPC5, DYRK1A e MACROD2 são os prováveis causadores da deficiência intelectual, atraso do desenvolvimento neuropsicomotor, dificuldades de aprendizagem, distúrbios de comportamento 
e outras características clínicas encontrados nos pacientes (Douglas et al., 2007; Grisart et al., 2008; Liao et al., 2013; Quélin et al., 2009; Møller et al., 2008; Maas et al., 2007).

No restante dos pacientes $(23-74,2 \%)$ nos quais não detectamos CNVs aparentemente patogênicas, o sequenciamento de nova geração (NGS - nextgeneration sequencing) pode provavelmente revelar mutações em genes específicos associados à obesidade e deficiência intelectual.

Vários dos prováveis genes causadores da obesidade são altamente expressos ou conhecidos em atuar no sistema nervoso central, sugerindo a função das vias do sistema nervoso central na predisposição para obesidade em geral, como ocorre nas raras formas de obesidade monogênica (Choquet et al., 2010; Herrera et al. 2011). Alguns genes, incluindo FTO, BDNF, SH2B1 e NEGR1, demonstraram influenciar aspectos da função neuronal, particularmente no hipotálamo, reforçando a ideia de que a obesidade é, em parte, um distúrbio relacionado ao cérebro. Também para apoiar essa ligação significativa entre o cérebro e a obesidade, tem-se o aumento do risco de atrofia cerebral, disfunção cognitiva e demência em idades mais avançadas de indivíduos obesos (Curran et al., 2013).

Um achado interessante foi a presença de pacientes macrocefálicos $(p>97,5)$ na amostra estudada $(44 \%$ - 13 dos 29 pacientes em que esta informação estava disponível). Toriello et al. (2007) encontraram uma relação entre a obesidade e a macrocefalia, sugerindo que sejam características dependentes. Os 421 pacientes estudados eram crianças entre 4 e 12 anos de clínicas pediátricas onde $25 \%$ das crianças eram obesas (IMC $\geq p 95$ ) e $39 \%$ estavam em risco de desenvolver obesidade (IMC $\geq p 85$ ). $13,7 \%$ do grupo total 
de pacientes tinha macrocefalia (perímetro cefálico $\geq p 98$ ). Entre aqueles com obesidade, 34\% tinham macrocefalia e entre aqueles em risco de desenvolver obesidade, $30 \%$ tinham macrocefalia. Os autores também constataram, através da análise de regressão múltipla, que o peso era mais importante do que a altura para determinar variações no perímetro cefálico. Desta maneira, esperavam que a macrocefalia ocorresse durante o desenvolvimento da criança. Para verificar esta afirmação, analisaram as medidas de perímetro cefálico disponíveis, feitas até 2 anos de idade, das crianças com obesidade e macrocefalia. Identificaram que apenas 2/22 (9\%) tiveram macrocefalia por volta dos 2 anos de idade, concluindo que quase toda a macrocefalia claramente não era congênita, de forma a apoiar a hipótese de que a obesidade conduz de algum modo ao crescimento da cabeça.

Bi et al. (2013) demonstraram que a grande maioria dos ganhos (<1 MB) e perdas $(<0,5 \mathrm{Mb})$ de material genético de significado clínico incerto nos autossomos e no cromossomo X são herdadas. A maioria dessas CNVs é em regiões não associadas a doenças e, provavelmente, representam CNVs benignas, de maneira que, para CNVs de significado clínico incerto, os autores sugerem que se deve primeiro considerar o tamanho da CNV e o conteúdo genético antes de solicitar estudos dos genitores. Quando uma CNV rara é encontrada em um paciente, mas herdada de um progenitor saudável, é mais provável ser classificada como variante de significado desconhecido (VOUS) ou provavelmente benigna. Entretanto, um portador aparentemente saudável poderia ser um portador não-penetrante de uma CNV (Hehir-Kwa et al., 2013; Kearney et al., 2011). 
É importante ressaltar que uma CNV presente em uma região sem genes pode afetar um promotor ou enhancer de um gene e, indiretamente, romper este gene. Rearranjos genômicos podem levar a expressão anormal do gene por afetar elementos regulatórios enquanto que o gene permanece intacto. O conhecimento atual sobre os possíveis efeitos de uma CNV numa região de não codificação ainda é muito pobre fazendo a interpretação clínica de tais regiões e aconselhamento subsequente ao paciente difícil.

A grande maioria de efeitos de posição em humanos que têm sido descritas são devidas a translocações aparentemente equilibradas com pontos de quebra a até mesmo $1 \mathrm{Mb}$ de distância do gene intacto causador do fenótipo (Stankiewicz et al., 2010). Isto demonstra a importância do estudo citogenético para a verificação de possíveis alterações estruturais, dado que arrays não determinam nem a posição ou a orientação da informação, somente o número relativo de cópias de segmentos relacionados a controles. Caso o segmento duplicado esteja translocado no genoma, é interpretado como provavelmente patogênico, como é o caso do paciente 20 , com o segmento duplicado do cromossomo 12 translocado ao braço curto do cromossomo 8 .

Evidências sugerem que alelos patogênicos relacionados a doenças recessivas que também apresentam CNVs ocorrem frequentemente, de maneira que uma perda heterozigótica em ambos os pais pode resultar em uma perda homozigótica clinicamente relevante na criança. Da mesma forma, quando um dos pais é portador de uma deleção que contém um gene recessivo e o outro progenitor é portador de uma mutação no mesmo gene, a heterozigosidade composta pode levar a uma prole afetada (Hehir-Kwa et al., 2013). 
Os pacientes 16 (deleções em 3q e 13q) e 20 (deleção em 8p e duplicação em 12p) poderiam também ser explicados pelo modelo "Two-hit", onde a combinação de duas ou mais CNVs podem explicar um fenótipo. Girirajan et al. (2010) estudaram pacientes com atraso do desenvolvimento com recorrentes microdeleções $16 \mathrm{p} 12.1$ e observaram um enriquecimento de grandes CNVs adicionais (maiores que $500 \mathrm{~kb}$ ), em comparação aos controles. Concluíram que pacientes com CNVs adicionais mostram um fenótipo clínico mais grave do que aqueles sem CNVs adicionais. Também há um aumento significativo da carga de CNVs em indivíduos com deficiência intelectual e anomalias múltiplas congênitas, em comparação com os indivíduos com deficiência intelectual isolada. Isso sugere que a carga total de CNVs correlaciona-se positivamente com a gravidade da deficiência na infância (Girirajan et al., 2011).

Microduplicações são mais frequentemente herdadas que microdeleções, talvez por resultar em um fenótipo mais leve que não afeta negativamente a capacidade reprodutiva. Por isso, uma cuidadosa avaliação clínica dos pais é recomendada quando a microduplicação é herdada, pois eles podem ter um fenótipo mais leve que o paciente. Isso é significante para aquelas microduplicações que são provavelmente patogênicas devido ao associado alto risco de recorrência (Stankiewicz et al., 2010).

Em apenas dois dos nossos pacientes a alteração encontrada foi herdada, onde em ambos os casos o pai era portador da CNV. Estas variações apresentam um significado clínico incerto. Em outros quatro casos não foi possível determinar a origem do rearranjo devido ao paciente ser adotado, ocorrer falha na técnica ou não termos disponível material para o estudo. Em 
dois casos a CNV era de novo. O fato dos genitores apresentarem cromossomos normais faz com que o risco de recorrência seja considerado desprezível.

A identificação de CNVs presentes no genoma que contribuem para a obesidade extrema associada à deficiência intelectual permite o diagnóstico de novas síndromes que apresentam fenótipos semelhantes aos de síndromes já conhecidas, ampliando o espectro de variabilidade fenotípica das síndromes associadas com obesidade.

O estudo de pacientes com síndromes raras cuja obesidade é uma de suas características torna possível a localização de genes e mecanismos moleculares que também podem estar relacionados à obesidade comum presente na população em geral, permitindo futuramente o desenvolvimento de tratamentos e medidas preventivas para as formas comuns de obesidade. 
Conclusões 


\section{$\underline{\text { V-Conclusões }}$}

1. O estudo genético de 31 pacientes com obesidade e/ou hiperfagia associada a atraso do desenvolvimento neuropsicomotor, dificuldades de aprendizagem, distúrbios de comportamento e outras características clínicas resultou na detecção de CNVs em 8 pacientes, o que corresponde a $25,8 \%$ da amostra estudada. Dentre essas alterações, a duplicação 16p13.11p12.3 foi descrita como provavelmente benigna.

2. Algumas CNVs presentes no genoma contribuem para a obesidade extrema associada à deficiência intelectual. A identificação de tais CNVs permite o diagnóstico de novas síndromes que apresentam fenótipos semelhantes aos de síndromes já conhecidas, explicando a variabilidade fenotípica presente nos pacientes.

3. As alterações encontradas foram: deleção em 1p22.1p21.2; deleção em 3q25.33q26.1 e deleção em 13q31.2q32.1; duplicação em 7q36.2; deleção em 8p23.3p23.1 e duplicação em 12p13.33p13.31; duplicação 16p13.11p12.3; duplicação em 17q11.2; deleção em 20p12.1; duplicação em 21q22.13.

4. Algumas alterações encontradas estão localizadas em regiões de síndromes descritas como tendo a obesidade com uma de suas principais características. A microdeleção de 1p21.3, as duplicações do cromossomo 21 e a duplicação do gene GNB3 (cromossomo 12p13.31) 
mostram pacientes com tendência a desenvolver a obesidade ou já obesos.

5. Nos segmentos alterados foram encontrados genes já descritos como associados à obesidade (PTBP2, DPYD, MIR137, GNB3 e PPM1L) ou possivelmente envolvidos com este fenótipo (HTR5A e KCNJ6).

6. Os genes RNF135, NF1, DPP6, GPC5, DYRK1A e MACROD2 são os prováveis causadores da deficiência intelectual, atraso do desenvolvimento neuropsicomotor, dificuldades de aprendizagem, distúrbios de comportamento e/ou outras características clínicas encontrados nos pacientes.

7. Dez genitores foram analisados por array-CGH, qPCR, FISH e/ou cariótipo. Apenas dois genitores eram portadores da CNV estudada, ambos os casos apresentando um significado clínico incerto. Em dois pacientes a CNV era comprovadamente de novo, tendo um risco de recorrência considerado desprezível. 


\section{Resumo}




\section{$\underline{\text { VI - Resumo }}$}

A obesidade se tornou uma das maiores preocupações de saúde pública. É um distúrbio neuroendócrino, no qual fatores ambientais e genéticos agem em conjunto, levando ao excesso de armazenamento de energia na forma de gordura corporal. A síndrome de Prader-Willi (PWS) é a mais freqüente das síndromes que possui a obesidade como uma de suas características, com incidência de 1:25.000 nascimentos. É caracterizada por hipotonia neonatal com dificuldade de sucção, atraso do desenvolvimento neuropsicomotor (DNPM), hiperfagia, obesidade, baixa estatura em adolescentes, mãos e pés pequenos, hipogonadismo, distúrbios do sono, características faciais dismórficas, deficiência intelectual leve a moderada e comportamento obsessivo-compulsivo. Pacientes com atraso do DNPM e/ou dificuldade de aprendizado, distúrbios de comportamento, obesidade e/ou hiperfagia, com teste negativo para PWS, foram estudados com plataformas de SNP array, "The GeneChip ${ }^{\circledR}$ Mapping 500K Set" da Affymetrix, ou array-CGH, CytoSure ISCA 4x180k da OGT, para identificar genes relacionados a obesidade e hiperfagia, assim como, novas regiões genômicas implicadas na etiologia de síndromes genéticas associadas à obesidade. Dentre os 31 pacientes estudados, oito apresentaram variações de número de cópias (CNVs) em seu genoma: deleção em 1p22.1p21.2; deleção em 3q25.33q26.1 e deleção em 13q31.2q32.1; duplicação em 7q36.2; deleção em 8p23.3p23.1 e duplicação em 12p13.33p13.31; duplicação 16p13.11p12.3; duplicação em 17q11.2; deleção em 20p12.1; duplicação em 21q22.13. Duas dessas alterações foram herdadas de pais fenotipicamente normais. Algumas dessas 
CNVs sobrepõem regiões genômicas previamente relacionadas com obesidade, incluindo a microdeleção de 1p21.3 e as duplicações dos cromossomos 12 e 21. Identificamos genes anteriormente descritos como associados à obesidade (PTBP2, DPYD, MIR137, GNB3 e PPM1L), ou possivelmente envolvidos com este fenótipo (HTR5A e KCNJ6), mapeados em várias dessas CNVs. Além disso, os genes RNF135, NF1, DPP6, GPC5, $D Y R K 1 A$ e MACROD2 são os prováveis causadores da deficiência intelectual, atraso do desenvolvimento neuropsicomotor, dificuldades de aprendizagem, distúrbios de comportamento e outras características clínicas encontrados nos pacientes. O diagnóstico e prognóstico dos pacientes e o Aconselhamento Genético aos pais e familiares é fornecido. 
Abstract 


\section{VII - Abstract}

Obesity has become a major concern for public health. It is a neuroendocrine disorder, in which genetic and environmental factors act together, leading to excessive storage of energy as fat. Prader-Willi syndrome (PWS) is the main obesity-related syndrome with a birth incidence of 1:25,000. It is characterized by neonatal hypotonia, poor sucking, developmental delay, hyperphagia, obesity, short stature in adolescents, small hands and feet, hypogonadism, sleep disturbance, dysmorphic facial features, mild to moderate intellectual disability and obsessive-compulsive behavior. Patients with psychomotor developmental delay and/or learning disabilities, behavior disorders, obesity and/or hyperphagia, who tested negative for PWS, were studied by chromosomal microarray analysis, including the SNP-based platform “The GeneChip® Mapping 500K Set” (Affymetrix), and the array-CGH platform "CytoSure ISCA 4x180k (OGT)", to identify genes related to hyperphagia and obesity, as well as new genomic regions implicated in the etiology of genetic syndromes associated with obesity. Of 31 patients studied, eight had copy number variants (CNVs) in the genome: 1p22.1p21.2 deletion; 3q25.33q26.1 deletion and 13q31.2q32.1 deletion; 7q36.2 duplication; 8p23.3p23.1 deletion and 12p13.33p13.31 duplication; 16p13.11p12.3 duplication; $17 q 11.2$ duplicaton; 20p12.1 deletion; 21q22.13 duplication. Two of these CNVs were inherited from an unaffected father. Some of these CNVs overlap genomic regions that have previously been related to obesity, including the $1 \mathrm{p} 21.3$ microdeletion and the duplications of chromosomes 12 and 21. Furthermore, we identified genes previously described as associated with obesity (PTBP2, 
DPYD, MIR137, GNB3 and PPM1L), or possibly involved with this phenotype (HTR5A and KCNJ6), mapped to several of these CNVs. In addition, the genes RNF135, NF1, DPP6, GPC5, DYRK1A and MACROD2 are likely implicated in intellectual disability, developmental delay, learning disabilities, behavioral disorders and other clinical features found in patients. The diagnosis and prognosis of patients and genetic counseling to parents and families is provided. 
Anexo 1 


\section{VIII - Anexo 1}

\section{Paciente 1}

J. P. S., sexo feminino, 9 anos na ocasião da consulta. Pai com 48 e mãe com 44 anos, não-consanguíneos, 2 abortos naturais. Irmãs de 13, 7 e 3 anos, saudáveis. A paciente foi encaminhada ao nosso serviço com suspeita de síndrome de Prader-Willi. Relato de casos na família: prima da mãe com aproximadamente 30 anos com deficiência intelectual grave. A gestação durou 9 meses. Parto cesáreo, peso ao nascimento $4100 \mathrm{~g}$ e comprimento $51 \mathrm{~cm}$, chorou e possuía boa sucção. Amamentação no peito até 6 meses. Firmou a cabeça aos 8 meses. Sentou sem apoio no $10^{\circ}$ mês. Andou com 1 ano e 6 meses. Começou a frequentar a escola com 3 anos e 6 meses. Desenvolveu frases e controle esfincteriano aproximadamente com 4 anos. Atraso do desenvolvimento global, problemas de aprendizado. Não desenvolveu a leitura e escrita. Problemas de articulação da fala. Rápido e excessivo ganho de peso entre 1 e 6 anos.

Na ocasião da consulta apresentava a estatura 1,38 m (p75-p90) e peso $52,5 \mathrm{~kg}(\mathrm{p}>97,5)$. Estatura abaixo do percentil familiar (apesar de normal). Lóbulo preso. Pescoço curto e grosso. Palato alto. Clinodactilia no $5^{\circ}$ dedo das mãos. Caminha com os pés virados para dentro. Obesidade com hiperfagia, obsessão por comida e polifagia. Intestino preso e infecção de urina recorrente. Saliva viscosa. Teimosia, acessos de violência, variações rápidas de humor, comportamento obsessivo/compulsivo, mentiras e roubos principalmente referentes à comida. Grita muito. Choro forte. Hábito de cutucar feridas. Alto 
limiar para dor. Diminuição da capacidade de vomitar. EEG (Eletroencefalograma) normal.

Cariótipo 46,XX, estudo do padrão de metilação da região PWS/, teste de MLPA com os kits P070-B1 e P064-B2 normais.

O emprego dos arrays GeneChip Mapping 500K (Affymetrix) e CytoSure ISCA 8x60k (OGT) não detectou alterações no genoma deste paciente. 


\section{Paciente 2}

G. F. S., sexo masculino, 6 anos. Pai com 43 e mãe com 36 anos, nãoconsanguíneos, não há histórico de abortos. Filho único. O paciente foi encaminhado ao nosso serviço com suspeita de síndrome de Prader-Willi. Relato de casos na família: um sobrinho da mãe não falava, não andava e faleceu aos 4 anos por causa desconhecida. A gestação durou 40 semanas. Parto cesário devido a hipertensão arterial materna, peso ao nascimento 2800 g. Diminuição de movimentos fetais. Sucção boa e quadro de icterícia. Firmou a cabeça com 3 meses, sentou sem apoio aos 5 meses e começou a andar com 1 ano e 9 meses. Rápido e excessivo ganho de peso aos 3 anos. Ingressou na escola com 5 anos. Teve rubéola. Deficiência intelectual grave. Não fala. Ri muito.

$\mathrm{Na}$ ocasião da consulta (15/03/2010) apresentava a estatura $1,21 \mathrm{~m}$ (p90-p97,5) e peso 31,4 kg (>p97,5), perímetro cefálico 53,5 cm (p90-p97,5). Dismorfismos leves. Estrabismo esquerdo. Orelha com lóbulo solto. Pescoço curto e grosso. Não possui controle esfincteriano. Testículos pequenos. Clinodactilia no $5^{\circ}$ dedo de ambas as mãos. Hiperfagia. Problemas de comportamento: teimosia, acessos de violência, comportamento obsessivo, roubos de comida. Hiperativo. Distúrbios de sono. Hábito de cutucar feridas. Alto limiar para dor. Diminuição da capacidade de vomitar. Medicado com neuleptil por orientação da psiquiatra.

Ressonância magnética crânio/encefálica normal. EEG com um foco irritativo temporal direito.

Cariótipo 46,XY. Pesquisa para sítio frágil do X, Estudo do padrão de metilação da região PWS/AS e teste de MLPA com o kit P064-B2 normais. 
No retorno para coleta de material para estudo citogenético (15/08/2011) o paciente apresentava a estatura de 1,38 m (>p97,5) e peso 43,8 kg (>p97,5), além de padrões comportamentais característicos: Alegre, crise de riso. Curioso e agitado.

O emprego dos arrays GeneChip Mapping 500K (Affymetrix) e CytoSure ISCA 8x60k (OGT) não detectou alterações no genoma deste paciente. 


\section{Paciente 3}

E. N. A., sexo masculino, 11 meses. Pai com 44 e mãe com 34 anos, não-consanguíneos, não há histórico de abortos. Irmã de 7 anos saudável. 0 paciente foi encaminhado ao nosso serviço com suspeita de obesidade sindrômica. Relato de casos na família: alguns casos de obesidade, além de demora em sentar. A gestação durou 37 semanas, ocorrência de febre com uso de antibióticos desde o inicio (sinusite); mãe fez densitometria óssea no inicio da gestação, pois desconhecia a gravidez. Parto Cesário devido a ausência de dilatação, peso ao nascimento $2620 \mathrm{~g}$ e comprimento $44 \mathrm{~cm}$; apresentou cianose. Com 45 dias teve pneumonia aspirativa, tinha refluxo. Atraso no desenvolvimento associado à hipotonia e déficit de sucção nos primeiros dias de vida.

Na ocasião da consulta (05/04/2010) apresentava a estatura $76 \mathrm{~cm}$ (p50p75) e peso 11,4 kg (p75-p90), perímetro cefálico $44 \mathrm{~cm}$ (p10-p25). Fontanela fechada, braquicefalia, fronte alta e estreita, implantação alta de cabelos na fronte, muito cabelo, bem espetado, pele e cabelos claros, sinofre, telecanto a direita e esquerda, hipertelorismo, estrabismo, fendas palpebrais estreitas, olhos levemente fundos, prega epicântica interna. Narinas antevertidas, lábios finos, filtro aumentado. Pregas palmares normais, camptodactilia $4^{\circ}$ dedo em ambas as mãos. Nos membros inferiores apresentava sindactilia no $3^{\circ}$ e $4^{\circ}$ dedo e clinodactilia no $4^{\circ}$ e $5^{\circ}$ dedo. Pavilhões auriculares com hélice espessa. Mamilos invertidos. Pênis pequeno, testículos tópicos.

EEG, ressonância magnética de crânio, avaliação auditiva e oftalmológica normais. 
Cariótipo 46,XY (realizado em outro laboratório). Estudo do padrão de metilação da região PWS/AS e teste de MLPA com o kit P064-B2 normais.

O emprego dos arrays GeneChip Mapping 500K (Affymetrix) e CytoSure ISCA 8x60k (OGT) não detectou alterações no genoma deste paciente. 


\section{Paciente 4}

G. A. O., sexo masculino, 8 anos. Pai com 53 e mãe com 49 anos, nãoconsanguíneos, não há histórico de abortos. Irmãos de 13 e 11 anos, saudáveis. O paciente foi encaminhado ao nosso serviço com suspeita de síndrome de Prader-Willi. A gestação durou 40 semanas, mãe utilizou antibióticos. Parto cesáreo devido a criança estar "sentada", peso ao nascimento $2960 \mathrm{~g}$ e comprimento $47,5 \mathrm{~cm}$, chorou e possuía boa sucção; apgar 8-9. Diminuição dos movimentos fetais. Choro fraco que melhorou com a idade. Instabilidade da temperatura corpórea. Com 2 meses teve broncopneumonia. Firmou a cabeça aos 7 meses. Sentou sem apoio 11 meses. Rápido e excessivo ganho de peso no $1^{\circ}$ ano. Andou com 2 anos. Adquiriu a capacidade de formular frases com aproximadamente 3 anos. Frequenta a escola desde os 4 anos. Controle esfincteriano aos 5 anos. Problemas de articulação da fala. Fala pouco e com dificuldade. Atraso no desenvolvimento global e de aprendizado, deficiência intelectual leve. Não desenvolveu a leitura, escrita e uso das operações matemáticas.

Na ocasião da consulta apresentava a estatura 1,42 m ( $p>97,5)$, peso 42 $\mathrm{kg}(p>97,5)$ e perímetro cefálico $57 \mathrm{~cm}(p>97,5)$. Hipotonia. Fronte ampla e abaulada, implantação alta de cabelos na fronte. Lóbulo solto. Déficit auditivo. Sinofre, epicanto, inclinação mongólica dos olhos, hipertelorismo, olhos amendoados. Lábio superior fino e inferior grosso. Boca pequena, dentes mal implantados, incisivos centrais proeminentes. Pescoço curto e grosso. Pênis pequeno, criptorquidismo. Dedos levemente afilados na ponta, clinodactilia do $5^{\circ}$ dedo das mãos. Pés pequenos. Suspeita de cardiopatia congênita. Marcha com dificuldades. Hiperfagia e obsessão por comida. Teimosia, acessos de 
violência, comportamento obsessivo, roubos principalmente referente à comida. Distúrbios de sono. Hábito de cutucar feridas. Alto limiar para a dor. Diminuição da capacidade de vomitar.

EEG, Estudo ecocardiográfico e US abdome total normais. Pressão arterial elevada.

Cariótipo 46,XY (realizado em outro laboratório). Estudo do padrão de metilação da região PWS/AS e teste de MLPA com o kit P064-B2 normais.

O emprego dos arrays GeneChip Mapping 500K (Affymetrix) e CytoSure ISCA 8x60k (OGT) não detectou alterações no genoma deste paciente. 


\section{Paciente 5}

F. A. S., sexo feminino, 13 anos, pais saudáveis. Pai com 38 e mãe com 37 anos, não-consanguíneos, não há histórico de abortos. Irmã de 15 anos, saudável. A paciente foi encaminhada ao nosso serviço com suspeita de síndrome de Prader-Willi. Relato de casos na família: filho de 15 anos da prima do pai apresenta deficiência intelectual. A gestação durou 9 meses, ocorrência de hipertensão arterial da mãe com uso de medicamento. Parto normal, peso ao nascimento $2750 \mathrm{~g}$ e comprimento $49 \mathrm{~cm}$, não chorou e possuía boa sucção; quadro de icterícia. Com 2 dias engasgou no berçário e houve demora para reanimá-la (sic). Firmou a cabeça com 9 meses. Início da dentição após completar 1 ano. Sentou sem apoio e iniciou a elaboração de frases com aproximadamente 1 ano e 6 meses. Andou e adquiriu controle esfincteriano com 3 anos. Teve caxumba. Rápido e excessivo ganho de peso aos 6 anos. Deficiência intelectual leve e problemas de aprendizado. Não desenvolveu a leitura e uso das operações matemáticas; quanto a escrita somente copia. Frequenta escola para crianças especiais. Fala normal, ri demasiadamente.

$\mathrm{Na}$ ocasião da consulta apresentava a estatura 1,60 m (p75-p90), peso $85,5 \mathrm{~kg}(\mathrm{p}>97,5)$ e perímetro cefálico $58 \mathrm{~cm}(p>97,5)$. Pescoço curto e grosso. Orelhas normais, lóbulo preso. Hiperacusia. Inclinação mongólica dos olhos. Miopia e astigmatismo, baixa acuidade visual. Lábio superior grosso. Palato alto. Filtro bem desenhado. Saliva viscosa. Clinodactilia do $5^{\circ}$ dedo das mãos. Pele apresenta manchas. Menarca aos 11 anos. Obesidade com obsessão por comida. Tem diabetes. Teimosia, variações rápidas de humor, comportamento obsessivo/compulsivo. Distúrbios de sono. Habito de cutucar feridas. Alto limiar 
para dor. Nunca vomitou. Manifesta sentir muito calor. Hiperatividade com uso dos medicamentos geodon e ritalina.

Tomografia computadorizada do crânio normal. EEG anormal devido a alentecimento e atividade epileptiforme de quadrante posterior esquerdo.

Cariótipo 46,XX. Estudo do padrão de metilação da região PWS/AS e teste de MLPA com o kit P064-B2 normais.

O emprego dos arrays GeneChip Mapping 500K (Affymetrix) e CytoSure ISCA 8x60k (OGT) não detectou alterações no genoma deste paciente. 


\section{Paciente 6}

R. G. F. S., sexo masculino, 10 anos. Pai com 55 e mãe com 38 anos, não-consanguíneos; a mãe aos 15 anos teve uma menina prematura de 7 meses com outro marido que faleceu com 7 dias de vida, além de 2 abortos provocados. Irmã com 2 anos, saudável. O pai teve com primeira esposa 1 menino e 2 meninas, a esposa teve 3 abortos espontâneos com aproximadamente 3 meses; os filhos do primeiro casamento são casados e tem filhos sendo uma das netas com paralisia infantil; as filhas são obesas com aproximadamente $120 \mathrm{~kg}$. Pai é fumante. O paciente foi encaminhado ao nosso serviço com suspeita de síndrome de Prader-Willi. A gestação durou 34 semanas. Parto normal, placenta rompeu às $6 \mathrm{~h}$ e o nascimento ocorreu às 20 h; apgar 9-9; peso ao nascimento $2235 \mathrm{~g}$, comprimento $42,5 \mathrm{~cm}$ e perímetro cefálico $31 \mathrm{~cm}$, choro fraco, sucção boa; icterícia com recomendação de banho de luz. Firmou a cabeça com 1 ano e 2 meses, sentou sem apoio com 2 anos e 3 meses, elaboração de frases com aproximadamente 1 ano; controle esfincteriano 5 anos. Desde os 5 anos está em tratamento que inclui 8 cirurgias para andar, para problemas no quadril, pernas e tendões, não anda sozinho. Neurologista afirma que o paciente teve paralisia cerebral. Atraso DNPM. Não lê, escreve ou faz contas. O paciente já teve rubéola, catapora, sarampo.

Na ocasião da consulta apresentava a estatura 1,47 m (p90-p97,5), peso 58,4 kg (p>97,5) e perímetro cefálico 55 cm (p90-p97,5). Crânio dismórfico, fronte alta e estreita. Hipermetropia. Orelhas grandes. Palato alto. Idade óssea comparável ao padrão masculino para 13 anos. Mãos $18 \mathrm{~cm}$. EEG normal.

Estudo do padrão de metilação da região PWS/AS e teste de MLPA com o kit P064-B2 normais. 
O emprego dos arrays GeneChip Mapping 500K (Affymetrix) e CytoSure ISCA 8x60k (OGT) não detectou alterações no genoma deste paciente. 


\section{Paciente 7}

W. A. N., sexo masculino, 12 anos. Pai com 37 e mãe com 34 anos, nãoconsanguíneos, não há histórico de abortos. Irmão 9 anos saudável. Pai foi relatado com problema de alcoolismo. O paciente foi encaminhado ao nosso serviço com suspeita de síndrome de Prader-Willi/obesidade sindrômica. A gestação durou 9 meses, hipertensão arterial diagnosticada 1 semana antes do parto com necessidade de internação. Parto cesáreo devido a ausência de dilatação, peso ao nascimento $3110 \mathrm{~g}$ e comprimento $48 \mathrm{~cm}$, ocorrência de choro e sucção. Firmou a cabeça com 4 meses, sentou sem apoio entre o $7^{\circ} \mathrm{e}$ $8^{\circ}$ mês e começou a andar e formular frases com 1 ano. Ingressou na escola com 4 anos, lê pouco, escreve seu próprio nome, faz contas, porém possui dificuldade de aprendizagem. Rápido e excessivo ganho de peso entre 1 e 6 anos.

$\mathrm{Na}$ ocasião da consulta (29/11/2010) apresentava a estatura $1,47 \mathrm{~m}$ (p50-p75) e peso $69 \mathrm{~kg}(p>97,5)$, perímetro cefálico $52 \mathrm{~cm}$ (p25-p50). Fronte baixa, estreita. Pescoço curto. Olhos fundos, inclinação mongólica ligeira. Miopia. Audição diminuída. Micrognatismo, lábio superior fino, inferior grosso, filtro pouco desenhado. Não demonstra sinal de puberdade. Clinodactilia $5^{\circ}$ dedo de ambas as mãos. Hemangioma no braço e peito esquerdos. Sopro cardíaco descoberto em 2008. Suspeita de problema renal. Distúrbios comportamentais como teimosia e acessos de violência. Distúrbios de sono. Hábito de cutucar feridas. Não tem diminuição na capacidade de vomitar. Hiperfagia.

No retorno para coleta de material para estudo citogenético (22/08/2011) o paciente apresentava a estatura de 1,52 m (p50), peso 70,2 kg (p>97,5) e 
perímetro cefálico $55 \mathrm{~cm}$ (p50-p75). Colesterol alto. Glicemia em jejum 105 $\mathrm{ml} / \mathrm{dL}$.

Cariótipo 46,XY. Estudo do padrão de metilação da região PWS/AS e teste de MLPA com os kits P036-E1 e P070-B1 normais.

O emprego dos arrays GeneChip Mapping 500K (Affymetrix) e CytoSure ISCA 8x60k (OGT) não detectou alterações no genoma deste paciente. 


\section{Paciente 8}

S. R. C., sexo feminino, 7 anos e 11 meses. Pai com 28 e mãe com 29 anos. Irmã de 6 anos, saudável. A paciente foi encaminhada ao nosso serviço com suspeita de obesidade sindrômica. A gestação durou 8 meses e meio, apresentou quadro de anemia. Parto normal, peso ao nascimento $2935 \mathrm{~g} \mathrm{e}$ comprimento $47 \mathrm{~cm}$, demorou a chorar, sucção normal. Sentou sem apoio aos 8 meses. Começou a andar com 3 anos. A partir dos 4 anos se comunicava através de palavras e gestos. Deficiência intelectual.

$\mathrm{Na}$ ocasião da consulta apresentava a estatura 1,15 m (p2,5-p10), peso $38 \mathrm{~kg}(p>97,5)$ e perímetro cefálico 47,5 cm ( $p<10)$. Microcefalia, braquicefalia, abaulamento frontal, fronte baixa e estreita, implantação de cabelos baixa na

nuca. Pescoço curto. Orelhas grandes, lóbulo solto. Nistagmo e estrabismo. Narinas antevertidas. Incisivos separados, filtro bem desenhado, lábios levemente grossos, microstomia. Macrognatismo. Clinodactilia $5^{\circ}$ dedo das mãos. Vomita muito, não possui muitos movimentos do lado direito (canhota). Única ocorrência de convulsão febril.

EEG, BERA, Tomografia computadorizada do crânio, Ressonância Magnética Nuclear do encéfalo, função tireoidiana, normais.

Cariótipo (realizado em outro laboratório), pesquisa para sítio frágil do $X$ e teste de MLPA com os kits P036-E1 e P070-B1 normais.

O emprego dos arrays GeneChip Mapping 500K (Affymetrix) e CytoSure ISCA 8x60k (OGT) não detectou alterações no genoma deste paciente. 


\section{Paciente 10}

J.A. sexo masculino, 13 anos. Pai com 55 e mãe com 39 anos, nãoconsanguíneos. Irmã com 22 anos com dificuldade de aprendizagem grave. Pai alcoólatra; tem uma irmã obesa e com hiperfagia. O paciente foi encaminhado ao nosso serviço devido à obesidade, dificuldades de aprendizagem e hipogenitalismo. A hipótese diagnóstica de síndrome de Prader-Willi foi afastada pela falta de características clínicas como ausência de hipotonia, presença de sucção ao nascimento e hiperfagia após os 6 anos (iniciou-se no paciente por volta dos 9 anos). A gestação durou 9 meses, com a ocorrência de febre e infecção urinária no início da gestação. Parto cesáreo devido a apresentação pélvica, peso ao nascimento 4000 g. Chorou, sucção normal. Firmou a cabeça com 3-4 meses, sentou sem apoio com 6 meses, andou com 1 ano e 6 meses. Escreve, porém não lê. Ecolalia. Atraso no desenvolvimento neuropsicomotor.

Na ocasião da consulta apresentava a estatura 1,62 m (p75-p90), peso $92 \mathrm{~kg}(p>97,5)$ e perímetro cefálico $55 \mathrm{~cm}$ (p75-p90). Fronte estreita. Implantação baixa de cabelos na fronte e nuca. Orelhas grandes, lóbulo solto. Olhos com inclinação mongólica. Ceratocone bilateral. Nariz pequeno. Lábio superior fino e inferior grosso. Palato alto; filtro longo e liso. Pescoço curto. Criptorquidia. Mãos grandes (18 cm - p50). Pés planos.

Há também a suspeita de Síndrome de Bardet-Biedl devido à obesidade, ceratocone, hipogonadismo e dificuldades de aprendizagem (características major).

Cariótipo 46,XY. 
O emprego do array CytoSure ISCA 4x180k (OGT) não detectou alterações no genoma deste paciente. 


\section{Paciente 13}

W.S.F.F., sexo masculino, 4 anos e 5 meses. Pai com 40 anos, também obeso, e mãe com 42 anos, não-consanguíneos. Um irmão de 11 anos teve febre reumática aos 6 anos, tratando-se até os dias de hoje e uma irmã de 8 anos saudável. Ocorrência de 2 abortos espontâneos. O paciente foi encaminhado ao nosso serviço com suspeita de obesidade e hipotonia leve. A gestação durou 38 semanas, com o uso de Sibutramina no início da gestação. Parto cesáreo com apgar 8-9, peso ao nascimento $2970 \mathrm{~g}$ e comprimento 46,5 cm. Demorou a chorar, sucção normal, porém mãe tinha pouco leite. Hipotonia. Firmou a cabeça com 3 meses, sentou sem apoio com 6 meses, andou com 1 ano e 3 meses.

$\mathrm{Na}$ ocasião da consulta apresentava a estatura 1,00 m (p10), peso 25,5 $\mathrm{kg}(>\mathrm{p} 97,5)$ e perímetro cefálico $55,5 \mathrm{~cm}(>\mathrm{p} 97,5)$. Braquicefalia, fronte alta e estreita, implantação baixa de cabelos na fronte. Orelhas grandes. Nariz pequeno. Microstomia, macrognatismo, lábios superior e inferior finos, filtro bem desenhado. Pescoço curto. Genitais normais. Membros inferiores com sindactilia bilateral total entre o $2^{\circ}$ e $3^{\circ}$ dedos. Teve rápido e excessivo ganho de peso, hiperfagia. Problemas de comportamento como teimosia e variações rápidas de humor. Leve atraso no desenvolvimento global.

Cariótipo 46,XY,inv(9)(p12q13), estudo do padrão de metilação da região PWS/AS, teste de MLPA com os kits P036-E1, P070-B1 e P064-B2 normais.

O emprego do array CytoSure ISCA 4x180k (OGT) não detectou alterações no genoma deste paciente. 


\section{Paciente 14}

R.R.P., sexo masculino, 28 anos. Pai com 57 e mãe com 61 anos, nãoconsanguíneos. Dois irmãos do sexo masculino saudáveis de 29 anos (altura de $1,82 \mathrm{~m})$ e 24 anos $(1,80 \mathrm{~m})$. O paciente foi encaminhado ao nosso serviço com suspeita de síndrome de Prader-Willi. A gestação durou 9 meses. Parto cesáreo devido a eclampsia, peso ao nascimento $3500 \mathrm{~g}$ e comprimento $52 \mathrm{~cm}$. Chorou, sucção fraca. Hipotonia. Firmou a cabeça depois de 1 ano, sentou sem apoio com 8 meses, andou com 3 anos, elaboração de frases em torno dos 3 anos, controle esfincteriano aos 3-4 anos. Quando começou a andar tornou-se hiperativo. Sabe ler e escrever, tem dificuldade em matemática. Fez tratamento com fonoaudiólogo. Tem atraso no desenvolvimento neuropsicomotor.

$\mathrm{Na}$ ocasião da consulta apresentava a estatura 1,82 m (p50-p75), peso $160 \mathrm{~kg}$ ( $p>95)$ e perímetro cefálico $61 \mathrm{Cm}(p>97)$. Fácies sindrômica. Braquicefalia, turricefalia. Boca aberta, língua protrusa. Prognatismo. Pênis pequeno. Mãos com $20 \mathrm{~cm}$ (p50), braquidactilia, dedos curtos e pregas palmares normais. Pés grandes (calça tamanho 48). Obesidade. Alto limiar para a dor. Alérgico. Pressão alta. Distúrbios do comportamento como agressividade e autoagressividade, teimosia e comportamento repetitivo.

Exames de triglicérides, colesterol e TSH normais.

Estudo do padrão de metilação da região PWS/AS e teste de MLPA com os kits P036-E1, P070-B1 e P064-B2 normais.

O emprego do array CytoSure ISCA 4x180k (OGT) não detectou alterações no genoma deste paciente. 


\section{Paciente 15}

I.P., sexo feminino, 12 anos. Pai com 36 e mãe com 40 anos, nãoconsanguíneos. Sem irmãos. A paciente foi encaminhada ao nosso serviço com suspeita de síndrome de Prader-Willi. A gestação durou 9 meses com a mãe sofrendo de infecção urinária no início e fim da gravidez. Exposição com proteção à radiação no braço quando estava com 8 meses. Parto cesáreo devido a falta de dilatação, peso ao nascimento $3975 \mathrm{~g}$ e comprimento $49 \mathrm{~cm}$. Firmou a cabeça aos 3 meses, sentou sem apoio aos 6 meses, andou com 1 ano, formou frases com 1 ano e 6 meses, entrando na escola com a mesma idade, porém não lê, não escreve e não faz contas. Deficiência no desenvolvimento da linguagem. Faz tratamento com fonoaudiólogo.

$\mathrm{Na}$ ocasião da consulta apresentava a estatura 1,57 m (p75-p90), peso $75,9 \mathrm{~kg}(p>97,5)$ e perímetro cefálico $57,5 \mathrm{~cm}(p>97,5)$. Fácies normal. Orelhas com $7 \mathrm{~cm}$ e lóbulo solto. Palato alto, filtro bem desenhado. Início da dentição aproximadamente aos 7 meses e segunda dentição aos 6 anos. Mãos com 18 cm (p95) e clinodactilia no $4^{\circ}$ dedo das mãos. Genitais normais, menarca aos 11 anos.

Teimosia. Obesidade com compulsão alimentar.

Cariótipo 46,XX (realizado em outro laboratório), estudo do padrão de metilação da região PWS/AS, teste de MLPA com os kits P036-E1, P070-B1 e P064-B2 normais.

O emprego do array CytoSure ISCA 4x180k (OGT) não detectou alterações no genoma deste paciente. 


\section{Paciente 17}

J.G., sexo feminino, 19 anos. Pai com 43 e mãe com 50 anos, nãoconsanguíneos, não há histórico de abortos. Irmã saudável. Primos por parte da mãe com deficiência intelectual. A paciente foi encaminhada ao nosso serviço com suspeita de síndrome de Prader-Willi/obesidade sindrômica. A gestação durou 9 meses. Parto cesáreo, peso ao nascimento $3049 \mathrm{~g}$ e comprimento $49 \mathrm{~cm}$, ocorrência de choro e sem sucção. Mãe não teve leite; tomou leite Nan, porém teve refluxo, passando a tomar leite de soja. Hipotonia. Andou com 1 ano e 4 meses e demorou a formular frases. Ingressou na escola em classe especial com 5 anos. Atraso no desenvolvimento cognitivo e articulação da fala. Fez cirurgia da adenoide. Teve convulsão em 2011.

$\mathrm{Na}$ ocasião da consulta apresentava a estatura 1,65 m (p50-p75), peso $137 \mathrm{~kg}$ ( $p>97,5)$ e perímetro cefálico $57 \mathrm{~cm}(p 90-p 97,5)$. Fronte alta. Pescoço curto e grosso. Orelhas pequenas $(6 \mathrm{~cm})$, lóbulo ligeiramente preso. Epicanto no olho esquerdo com inclinação ligeiramente mongólica e miopia (grau 3,5). Nariz com hiperplasia alar. Sobrancelhas largas. Microstomia. Boca pequena com lábio superior fino e inferior grosso. Filtro longo, bem desenhado. Dentes mal implantados. Início da dentição: em torno de 1 ano. Boca com cantos voltados para baixo. Pintas no rosto. Menarca aos 10 anos.

Rápido e excessivo ganho de peso entre 1 e 4 anos de idade. Obesidade mórbida com compulsão alimentar. Resistência à insulina. Problemas de comportamento: ansiedade, teimosia, comportamento obsessivo/compulsivo, mentiras, roubos. Distúrbios de sono. Hábito de cutucar feridas. Alto limiar para a dor. Não tem diminuição na capacidade de vomitar. Escoliose. 
Cariótipo 46,XX (realizado em outro laboratório), estudo do padrão de metilação da região PWS/AS e teste de MLPA com os kits P036-E1 e P064-B2 normais.

O emprego do array CytoSure ISCA 4x180k (OGT) não detectou alterações no genoma deste paciente. 


\section{Paciente 18}

M.A.M.S., sexo masculino, 3 anos e 11 meses. Pai com 56 e mãe com 41 anos. Irmão de 16 anos (por parte materna), saudável. Uma perda gestacional no primeiro trimestre. O paciente foi encaminhado ao nosso serviço com suspeita de síndrome de Prader-Willi. A gestação durou 39 semanas. Parto cesáreo devido a hipertensão, peso ao nascimento $3665 \mathrm{~g}$, comprimento $46,5 \mathrm{~cm}$, perímetro cefálico $34 \mathrm{~cm}$. Chorou e com sucção normal. Sentou sem apoio aos 6 meses. Começou a andar com 2 anos. A partir dos 3 anos começou a formar frases.

$\mathrm{Na}$ ocasião da consulta apresentava estatura de $90 \mathrm{~cm}$ (p2,5-p10), peso $25,4 \mathrm{~kg}(p>97,5)$ e perímetro cefálico $50 \mathrm{~cm}$ (p50-p75). Braquicefalia, turricefalia, fronte alta, implantação de cabelos alta na fronte e baixa na nuca. Pescoço curto. Orelhas com implantação baixa, lóbulo preso, hiperenrolamento de hélice. Sinofre, epicanto, inclinação mongólica dos olhos. Nariz bífido, achatado. Micrognatismo, boca de carpa. Lábio superior fino e inferior grosso. Palato alto e estreito, filtro longo, bem desenhado. Início da dentição aproximadamente aos 7 meses. Mamilos invertidos. Hipogenitalismo, micropênis. Mãos pequenas (direita 10,5cm; esquerda 10cm - p5-p50). Pé plano. Hirsutismo leve. Manchas café com leite no braço e manchas hipopigmentares segmentadas em ondas pelo corpo, semelhantes às presentes na hipomelanose de Ito.

Bastante tranquilo, não tem comportamento auto-agressivo. Quando irritado chora muito.

Exames realizados aos 12 meses de idade: FSH, LH, testosterona, androstenediona, hormônio do crescimento, erros inatos, US abdome total, RX 
tórax, RM crânio normais. Sulfato de dehidroepiandrosterona (DHEA-S) com resultado 83 microg/dL (referência para condições basais de 6 meses a 5 anos: até $15 \mathrm{microg} / \mathrm{dL})$.

Cariótipo 46,XY. Estudo do padrão de metilação para a região PWS/AS, teste de MLPA com os kits P064-B2, P036-E1, P070-B1 normais.

O emprego do array CytoSure ISCA 4x180k (OGT) não detectou alterações no genoma deste paciente. 


\section{Paciente 21}

L.F.S., sexo feminino, 12 anos. Pai com 46 e mãe com 47 anos. Uma irmã de 16 anos saudável. Mãe teve 1 perda gestacional no $1^{\circ}$ trimestre. Nega consanguinidade. A paciente foi encaminhada ao nosso serviço com suspeita de síndrome de Prader-Willi. A gestação durou 8 meses e meio, com febre no $1^{\circ}$ trimestre. Mãe fumou durante a gestação. Parto cesáreo devido a hipertensão, peso ao nascimento $3340 \mathrm{~g}$, comprimento $49 \mathrm{~cm}$. Demorou a chorar, com sucção normal. Não teve hipotonia neonatal. Firmou a cabeça entre 4 e 5 meses. Sentou sem apoio aos 9 meses. Começou a andar com 1 ano e 7 meses. A partir dos 2 anos começou a formar frases. Problemas de articulação da fala, como gagueira, levando a paciente a parar de falar. Utilizou fralda noturna até os 5 anos. Está na $6^{\mathrm{a}}$ série da escola, mas possui dificuldades de aprendizado, apesar de saber ler, escrever e fazer contas. Atraso leve do desenvolvimento neuropsicomotor.

$\mathrm{Na}$ ocasião da consulta apresentava a estatura 1,67 m ( $p>97,5)$, peso 95,4 $\mathrm{kg}(p>97,5)$ e perímetro cefálico $56 \mathrm{~cm}(p>97,5)$. Fronte alta, larga. Implantação alta de cabelos na fronte. Aos 4 anos os cabelos começaram a ficar brancos. Pescoço curto. Orelhas grandes com lóbulo preso. Inclinação mongólica dos olhos. Nariz grande. Lábios superior e inferior finos com filtro bem desenhado. Inicio da dentição após 1 ano. Genitais normais, com menarca aos 12 anos. Mãos grandes (18cm - p95) com dedos levemente afilados nas pontas. Apresenta acantose nigricans.

Com 6 meses de idade não ganhava peso em decorrência do refluxo que iniciou-se com 1 mês e meio e seguiu até os 5 anos. Teve um rápido e excessivo ganho de peso após os 3 anos, decorrente da má alimentação (não 
era compulsiva), porém desenvolveu a obsessão por comida posteriormente. Foi diagnosticada como cardiopata por apresentar taquicardia. Com 12 anos desenvolveu diabetes e hipertensão.

Problemas de comportamento como teimosia, variações rápidas de humor e comportamento obsessivo/compulsivo. Apresenta distúrbios do sono, dormindo muito durante o dia. Saliva viscosa. Hábito de cutucar feridas, alto limiar para a dor. Não tem diminuição da capacidade de vomitar. Escoliose.

Exames de tomografia computadorizada e ressonância magnética de crânio normais.

Cariótipo 46,XX. Estudo do padrão de metilação para a região PWS/AS, teste de MLPA com os kits P064-B2, P036-E1, P070-B1 e kit sintético de obesidade normais.

O emprego do array CytoSure ISCA 4x180k (OGT) não detectou alterações no genoma deste paciente. 


\section{Paciente 22}

C.A.S., sexo feminino, 13 anos. Pai com 60 e mãe com 52 anos. Irmãs de 25, 22 e 20 anos saudáveis. Mãe teve 1 perda gestacional no $1^{\circ}$ mês. Nega consanguinidade. A paciente foi encaminhada ao nosso serviço com suspeita de síndrome de Prader-Willi. A gestação durou 9 meses. Parto cesariana devido a ausência de dilatação, peso ao nascimento $2500 \mathrm{~g}$, estatura $52 \mathrm{~cm}$. Sem choro e sucção. Hipotonia neonatal. Firmou a cabeça com 1 ano. Sentou sem apoio aos 8 meses. Começou a andar com 3 ano e 6 meses. A partir dos 5 anos começou a formar frases. Iniciou estudos em escola especial aos 7 anos, sabe ler, escrever e fazer contas. Problemas de articulação da fala. Atraso no desenvolvimento global.

Na ocasião da consulta apresentava a estatura 1,435 m (p2,5-p10), peso 65,8 kg (p90-p95) e perímetro cefálico $55 \mathrm{~cm}$ ( $p>90)$. Braquicefalia. Pescoço curto e grosso. Orelhas grandes, em abano, lóbulo solto. Nariz pequeno. Lábio superior fino, palato alto. Inicio de dentição aos 7 meses e segunda dentição aos 8 anos. Genitais normais, menstrua desde os 9 anos. Mãos pequenas $(15 \mathrm{~cm}-\mathrm{p5})$, dedos afilados nas pontas com a borda ulnar reta e clinodactilia no $5^{\circ}$ dedo das mãos. Pés pequenos (calça $31 / 32$ ).

Problemas de alimentação na infância com pouco ganho de peso, apresentando um rápido e excessivo ganho de peso com 6 anos. Problemas de comportamento como teimosia, acessos de violência, comportamento obsessivo/compulsivo e mentiras. Hábito de cutucar feridas, alto limiar para a dor. Diminuição da capacidade de vomitar. Habilidade de montar quebracabeças. 
Exame de eletroencefalograma (EEG) anormal (resultado: atividade de fundo normal; raros surtos de ondas lentas de projeções encefálicas difusas). Tomografia computadorizada do crânio normal.

Raio X para a determinação da idade óssea resultou em 15 anos, sendo que a paciente apresentava a idade cronológica de 11 anos e 3 meses.

Estudo do padrão de metilação para a região PWS/AS normal.

O emprego do array CytoSure ISCA 4x180k (OGT) não detectou alterações no genoma deste paciente. 


\section{Paciente 24}

R.A.P.F., sexo masculino, 11 anos. Pai com 52 e mãe com 49 anos. Nega consanguinidade. Sem histórico de abortos. O paciente foi encaminhado ao nosso serviço com suspeita de síndrome de Angelman. A gestação durou 38 semanas. Parto fórceps (mãe ficou com mais de 24 horas com contração, resultando em uma lesão na cabeça da criança), peso ao nascimento $2560 \mathrm{~g}$, comprimento $49 \mathrm{~cm}$. Apresentou sucção e choro. Hipotonia. Firmou a cabeça com 3 meses. Sentou sem apoio aos 7 meses. Começou a andar com 11 meses. Controle esfincteriano aos 5 anos. Não fala. Entrou na escola aos 2 anos e 6 meses. Problemas de articulação da fala. Atraso no desenvolvimento neuropsicomotor.

$\mathrm{Na}$ ocasião da consulta apresentava a estatura 1,36 m (p10-p25), peso $58,4 \mathrm{~kg}(p>97,5)$ e perímetro cefálico $56 \mathrm{~cm}(p>97,5)$. Braquicefalia. Olhos fundos. Orelhas com lóbulo preso. Genitais normais. Mãos com dedos afilados nas pontas, unhas quadradas, pregas palmares normais e clinodactilia do $5^{\circ}$ dedo bilateral.

Convulsões a partir de 1 ano e 6 meses, sendo que perde habilidades já adquiridas todas as vezes que tem quadros convulsivos. Problemas de comportamento como autoagressão.

Ressonância magnética do encéfalo normal.

Cariótipo 46,XY. Estudo do padrão de metilação para a região PWS/AS, teste de MLPA com os kits P147 (para a deleção 1p36), P036-E1, P070-B1 normais.

O emprego do array CytoSure ISCA 4x180k (OGT) não detectou alterações no genoma deste paciente. 


\section{Paciente 25}

K.Z., sexo masculino, 14 anos. Pai e mãe com 43 anos. Nega consanguinidade. Sem histórico de abortos. O paciente foi encaminhado ao nosso serviço com suspeita de síndrome de Prader-Willi. A gestação durou 9 meses. Perdas sanguíneas no início da gravidez. Parto cesáreo, peso ao nascimento $3020 \mathrm{~g}$, comprimento $49 \mathrm{~cm}$, perímetro cefálico $34,5 \mathrm{~cm}$. Firmou a cabeça com 3 meses. Sentou sem apoio aos 6 meses. Começou a andar com 1 ano e 7 meses. Começou a formar frases a partir de 2 anos e 7 meses. Entrou na escola com 1 ano e 6 meses.

$\mathrm{Na}$ ocasião da consulta apresentava a estatura 1,59 m (p25-p50), peso $83 \mathrm{~kg}(p>97,5)$ e perímetro cefálico $57 \mathrm{~cm}(p>95)$. Abaulamento frontal. Implantação baixa de cabelos na fronte. Orelhas com lóbulos soltos. Lábios grossos, leve macrostomia, filtro curto, bem desenhado. Leve clinodactilia no $5^{\circ}$ dedo esquerdo; pregas palmares normais. Pênis pequeno e criptorquidia bilateral.

Começou a ter aumento excessivo de peso aos 7 anos. Faz uso de hormônio do crescimento $(\mathrm{GH})$ há pouco mais de 1 ano, onde ganhou $9 \mathrm{~cm}$ e 3 $\mathrm{kg}$.

Apresenta algumas alterações de DNPM, com diagnóstico de TDAH (Transtorno do Déficit de Atenção com Hiperatividade) pelo psiquiatra e uso de fluoxetina.

Exame de colesterol dentro da faixa de normalidade; testosterona em 198ng/dl (valor de referência: 240-816 ng/dl). Eletroencefalograma e ressonância magnética de hipotálamo-hipófise normais. 
Cariótipo 46,XY. Teste de MLPA com os kits P064-B2, P036-E1, P070B1 normais.

O emprego do array CytoSure ISCA 4x180k (OGT) mostrou uma duplicação intersticial do braço longo do cromossomo 7 (q35) de 9.4kb localizada em 147012133pb e 147021543pb, conforme o Ensembl Genome Browser (versão NCBI37/hg19).

Como a alteração abrange o gene CNTNAP2, previamente descrito na literatura, em que mutações e deleções neste gene resultam no transtorno do espectro autista (Peñagarikano \& Geschwind, 2012), optou-se por verificar se a alteração detectada no array era verdadeira, mesmo tratando-se de uma alteração pequena. Realizou-se a análise com qPCR, utilizando-se o gene CNTNAP2 para o desenho dos primers foward (AGTTCATGACCAGCCTGAGC) e reverse (TGGATCACTGCACTCCAAGG), onde não se confirmou a duplicação previamente observada. 


\section{Paciente 26}

P.H.B.B, sexo masculino, 7 anos. Pai falecido e mãe com 36 anos. Nega consanguinidade. Sem histórico de abortos. Um irmão de 19 anos saudável de outro pai. Sobrinho de 10 anos do pai apresenta deficiência intelectual. 0 paciente foi encaminhado ao nosso serviço com suspeita de síndrome de Prader-Willi. A gestação durou 9 meses. Parto normal, peso ao nascimento 2200g. Chorou e com boa sucção. Firmou a cabeça com 6 meses. Sentou sem apoio aos 8 meses. Começou a andar com 1 ano e 8 meses. Começou a formar frases em torno de 1 ano e 6 meses. Entrou na escola com 6 anos. Fala é normal. Não lê, não escreve e não faz contas.

$\mathrm{Na}$ ocasião da consulta apresentava a estatura 1,36 m ( $p>97,5)$, peso $58,6 \mathrm{~kg}(p>97,5)$ e perímetro cefálico $59 \mathrm{~cm}(p>97,5)$. Pescoço curto e grosso. Orelhas grandes com implantação baixa, grosseiras e lóbulo preso. Lábio superior fino, palato alto. Início da dentição aos 9 meses. Genitais normais.

Rápido e excessivo ganho de peso com 3 anos. Hiperfagia, obsessão por comida. Problemas de comportamento como teimosia e acessos de violência. Hiperativo. Distúrbios do sono. Não tem diminuição da capacidade de vomitar.

Ressonância magnética do crânio normal.

Cariótipo 46,XY. Estudo do padrão de metilação para a região PWS/AS, teste de MLPA com os kits P064-B2, P036-E1, P070-B1 normais.

O emprego do array CytoSure ISCA 4x180k (OGT) não detectou alterações no genoma deste paciente. 


\section{Paciente 27}

L.C.S.F., sexo masculino, 13 anos. Pai com 49 e mãe com 43 anos. Nega consanguinidade. Possui 4 irmãs de 25, 22, 16 e 11 anos saudáveis sendo que a mais nova tem dificuldade escolar e um irmão de 24 anos saudável. Sobrinha do pai com 20 anos tem muita dificuldade escolar e alguns primos da mãe apresentam distúrbios mentais. O paciente foi encaminhado ao nosso serviço com suspeita de síndrome da deleção 1p36. A gestação durou 9 meses. Parto normal, peso ao nascimento $3000 \mathrm{~g}$. Não chorou, sem suç̧ão. Firmou a cabeça com 4 meses. Sentou sem apoio aos 6 meses. Começou a andar com 2 anos. Começou a formar frases a partir de 3 anos. Controle esfincteriano aos 5 anos. Entrou na escola com 11 anos. Dificuldades de aprendizado (não lê, não escreve e não faz contas). Atraso do desenvolvimento neuropsicomotor.

$\mathrm{Na}$ ocasião da consulta apresentava a estatura 1,52 m (p25-p50), peso $77,5 \mathrm{~kg}(\mathrm{p}>97,5)$ e perímetro cefálico $55 \mathrm{~cm}$ (p75-p90). Braquicefalia. Pescoço curto e grosso. Olhos fundos. Orelhas grandes, assimétricas, de implantação baixa, levemente em abano, com lóbulo solto. Sinofre. Genitais normais, pênis pequeno. Ginecomastia. Pele e anexos: manchas hipo e hiperpigmentadas no abdômen na direção do púbis e na virilha, linha média hipopigmentada. Braquidactilia e clinodactilia do $5^{\circ}$ dedo.

Hiperfagia. Obesidade. Distúrbios de comportamento como agressividade e roubo de alimentos. Não tem diminuição da capacidade de vomitar.

Psicólogos diagnosticaram como Síndrome de Cornélia de Lange. 
Cariótipo 46,XY (realizado em outro laboratório). Estudo do padrão de metilação para a região PWS/AS, teste de MLPA com os kits P064-B2, P036$\mathrm{E} 1, \mathrm{P} 070-\mathrm{B} 1$ normais.

O emprego do array CytoSure ISCA 4x180k (OGT) não detectou alterações no genoma deste paciente. 


\section{Paciente 28}

H.O.B, sexo masculino, 5 anos e 9 meses. Idade dos pais não informada. Um irmão de 11 anos saudável. O paciente foi encaminhado ao nosso serviço com suspeita de Obesidade Sindrômica. A gestação durou 42 semanas. Perdas sanguíneas no início da gravidez. Parto cesáreo, peso ao nascimento $3490 \mathrm{~g}$, comprimento $49,5 \mathrm{~cm}$, perímetro cefálico $35 \mathrm{~cm}$. Chorou e com boa sucção. Firmou a cabeça com 3 meses. Sentou sem apoio com 1 ano. Começou a andar com 3 anos. Controle esfincteriano aos 3 anos. Começou a formar frases a partir de 3 anos. Problemas de articulação na fala. Dificuldades de aprendizado.

Internado com 1 ano e 10 dias devido a pressão alta. Apresentava excesso de peso $(23 \mathrm{~kg})$. Também teve glomerulonefrite em consequência da hipertensão arterial. Além disso, tem diabetes e colesterol alto.

$\mathrm{Na}$ ocasião da consulta apresentava a estatura 1,10 m (p10-p25), peso $48,6 \mathrm{~kg}(p>97,5)$ e perímetro cefálico $54 \mathrm{~cm}(p>97,5)$. Abaulamento frontal, fronte estreita. Pescoço curto. Orelhas grandes, levemente rotadas. Sinofre, epicanto no olho direito, telecanto, fenda palpebral estreita, reta. Micrognatismo; lábio superior grosso, evertido, lábio inferior grosso, filtro curto. Dentes pequenos. Abdômen protuso. Genitais normais. Mãos pequenas $(13 \mathrm{~cm}$ direita, $12,5 \mathrm{~cm}$ esquerda - p50), dedos curtos e afilados, unhas quadradas. Pele toda desenhada, com manchas hipopigmentares no abdômen e costas (hipomelanose de Ito), linha média mais clara.

Não é agressivo, nem em relação à comida. Diminuição da capacidade de vomitar (teve apenas um episódio). Dificuldades de respiração durante o sono (utiliza respirador mecânico). 
Cariótipo 46,XY. Estudo do padrão de metilação para a região PWS/AS, teste de MLPA com os kits P064-B2, P036-E1, P070-B1 normais.

O emprego do array CytoSure ISCA 4x180k (OGT) não detectou alterações no genoma deste paciente. 


\section{Paciente 29}

E.A.S., sexo masculino, 10 anos. Pai com 45 e mãe com 46 anos. Nega consanguinidade. Histórico de 2 abortos. Um irmão falecido (usuário de drogas), uma irmã de 19 anos e uma irmã de 14 anos acima do peso. Irmão da mãe faleceu aos 8 anos (tinha epilepsia, não falava corretamente, não andava). O paciente foi encaminhado ao nosso serviço com suspeita de obesidade sindrômica. A gestação durou 9 meses. Perdas sanguíneas no início da gravidez. Parto cesáreo, peso ao nascimento $2100 \mathrm{~g}$. Chorou, sem sucção (boca muito pequena). Hipotonia neonatal. Tímpano esquerdo perfurado congênito. Sentou sem apoio com 1 ano. Começou a andar com 1 ano e 6 meses. Controle esfincteriano aos 4 anos. Entrou na escola com 7 anos. Começou a formar frases a partir de 8 anos, com auxílio de fonoaudiólogo. Problemas de articulação na fala. Dificuldades de aprendizado.

$\mathrm{Na}$ ocasião da consulta apresentava a estatura 1,50 m (p95-p97), peso $68 \mathrm{~kg}(p>97,5)$ e perímetro cefálico $53 \mathrm{~cm}(p 75)$. Abaulamento frontal, fronte alta e estreita. Implantação alta de cabelos na fronte. Pescoço curto e grosso. Orelhas grandes com lóbulo preso. Olhos pequenos. Nariz em bico, ponte nasal um pouco alargada. Microstomia, retrognatismo, lábios finos. Úvula bífida. Palato muito estreito. Maloclusão, dentes muito tortos. Criptorquidia unilateral à esquerda, micropênis. Mãos com $17,5 \mathrm{~cm}$, pregas transicionais à direita.

Rápido e excessivo ganho de peso a partir de 5 anos. Hiperfagia, com alguns episódios de obsessão por comida. Hiperativo. Problemas de comportamento como teimosia e acessos de violência. Hábito de cutucar feridas. Não tem diminuição da capacidade de vomitar. 
Cariótipo 46,XY,inv(9)(p12q13). Estudo do padrão de metilação para a região PWS/AS, teste de MLPA com os kits P064-B2, P036-E1, P070-B1 normais.

O emprego do array CytoSure ISCA 4x180k (OGT) não detectou alterações no genoma deste paciente. 


\section{Paciente 30}

R.S.C., sexo feminino, 23 anos. Pai com $49(1,57 \mathrm{~m})$ e mãe com 43 anos $(1,55 \mathrm{~m})$. Primos em primeiro grau. Sem irmãos. A paciente foi encaminhada ao nosso serviço com suspeita de obesidade sindrômica. A gestação durou 9 meses. Parto cesáreo, peso ao nascimento $2600 \mathrm{~g}$, comprimento $49 \mathrm{~cm}$. Chorou, sucção normal. Firmou a cabeça com 3 meses. Sentou sem apoio com 6 meses. Começou a andar com 1 ano e 2 meses. Controle esfincteriano aos 2 anos. Começou a formar frases a partir de 3 anos. Entrou na escola com 4 anos. Problemas de articulação na fala. Ecolalia. Voz anasalada. Dificuldades de aprendizado. Lê, não escreve bem pela coordenação motora deficiente, não aprende matemática.

$\mathrm{Na}$ ocasião da consulta apresentava a estatura $1,48 \mathrm{~m}$, peso $89 \mathrm{~kg} \mathrm{e}$ perímetro cefálico $51,5 \mathrm{~cm}(\mathrm{p}<2,5)$ Braquicefalia, abaulamento frontal, fronte estreita. Pescoço curto. Inclinação mongólica dos olhos, hipertelorismo. Narinas antivertidas. Microstomia, macrognatismo, lábios finos. Genitais normais, menstrua normalmente. Mãos pequenas com $18 \mathrm{~cm}$ ( $p 50)$. Pés pequenos (calça $\left.n^{\circ} 34\right)$.

Obesidade com compulsão alimentar e hiperfagia. Problemas de comportamento como teimosia, acessos de violência, ansiedade, comportamento obsessivo-compulsivo. Atualmente provoca vômito quando se alimenta em excesso. Utiliza medicamento para dormir, pois sem ele não dorme nem à noite. Também utiliza Topiramato $(25 \mathrm{mg})$, Lexapro $(15 \mathrm{mg})$ e Risperidona (1mg).

Cariótipo 46,XX. Estudo do padrão de metilação para a região PWS/AS, teste de MLPA com os kits P064-B2, P036-E1, P070-B1 normais. 
O emprego do array CytoSure ISCA 4x180k (OGT) não detectou alterações no genoma deste paciente. 


\section{Referências bibliográficas}


$\underline{\text { IX - Referências Bibliográficas }}$

Referências Eletrônicas

CHORI: bacpac.chori.org/bacpacmini.htm

DECIPHER: http://decipher.sanger.ac.uk/

DGV Toronto: dgv.tcag.ca/dgv/app/home/

Ensembl Genome Browser: www.ensembl.org/

GeneCards: www.genecards.org/

ISCA: www.iscaconsortium.org/

OMIM: www.omim.org/

PubMed: www.ncbi.nlm.nih.gov/pubmed

University of California Santa Cruz Genome Bioinformatics:

genome.ucsc.edu/ 


\section{Referências Bibliográficas}

Alders M, Koopmann TT, Christiaans I, Postema PG, Beekman L, Tanck MW, Zeppenfeld K, Loh P, Koch KT, Demolombe S, Mannens MM, Bezzina CR, Wilde AA. Haplotype-sharing analysis implicates chromosome 7q36 harboring DPP6 in familial idiopathic ventricular fibrillation. Am J Hum Genet. 2009 Apr;84(4):468-76.

Al-Kateb H, Khanna G, Filges I, Hauser N, Grange DK, Shen J, Smyser CD, Kulkarni S, Shinawi M. Scoliosis and vertebral anomalies: Additional abnormal phenotypes associated with chromosome 16p11.2 rearrangement. Am J Med Genet A. 2014 Jan 23.

Arron JR, Winslow MM, Polleri A, Chang CP, Wu H, Gao X, Neilson JR, Chen L, Heit JJ, Kim SK, Yamasaki N, Miyakawa T, Francke U, Graef IA, Crabtree GR. NFAT dysregulation by increased dosage of DSCR1 and DYRK1A on chromosome 21. Nature. 2006 Jun 1;441(7093):595-600.

Bachmann-Gagescu R, Mefford HC, Cowan C, Glew GM, Hing AV, Wallace S, Bader PI, Hamati A, Reitnauer PJ, Smith R, Stockton DW, Muhle H, Helbig I, Eichler EE, Ballif BC, Rosenfeld J, Tsuchiya KD. Recurrent 200-kb deletions of 16p11.2 that include the SH2B1 gene are associated with developmental delay and obesity. Genet Med. 2010 Oct;12(10):641-7. 
Barness LA, Opitz JM, Gilbert-Barness E. Obesity: Genetic, molecular, and environmental aspects. Am J Med Genet. 2007 Part A 143A:3016-3034.

Bartnik M, Nowakowska B, Derwińska K, Wiśniowiecka-Kowalnik B, Kędzior M, Bernaciak J, Ziemkiewicz K, Gambin T, Sykulski M, Bezniakow N, Korniszewski L, Kutkowska-Kaźmierczak A, Klapecki J, Szczałuba K, Shaw CA, Mazurczak T, Gambin A, Obersztyn E, Bocian E, Stankiewicz P. Application of array comparative genomic hybridization in 256 patients with developmental delay or intellectual disability. J Appl Genet. 2014 Feb;55(1):125-44.

Beales, PF, Farooqi, IS. Introdution. In: Genetics of Obesity Syndromes. New York: Oxford University Press, Inc., 2009. P. 3-24.

Bell CG, Walley AJ, Froguel P. The genetics of human obesity. Nat Rev Genet. 2005 Mar;6(3):221-34.

Bi W, Pham J, Denham J, Roney E, Pursley AN, Stankiewicz P, Breman A, Lalani S, Smith J, Bacino C, Patel A, S. W. Cheung Baylor College of Medicine, Houston, TX. Parental Studies of 2,248 Chromosomal Microarray Analysis (CMA) Cases -Role of parental studies in facilitating the interpretation of copy number variants. Apresentação de Pôster no Congresso da ASHG - American Society of Human Genetics 2013, Boston, USA.

Bochukova EG, Huang N, Keogh J, Henning E, Purmann C, Blaszczyk K, Saeed S, Hamilton-Shield J, Clayton-Smith J, O'Rahilly S, Hurles ME, Farooqi 
IS. Large, rare chromosomal deletions associated with severe early-onset obesity. Nature. 2010 Feb 4;463(7281):666-70.

Bonnefond A, Raimondo A, Stutzmann F, Ghoussaini M, Ramachandrappa S, Bersten DC, Durand E, Vatin V, Balkau B, Lantieri O, Raverdy V, Pattou F, Van Hul W, Van Gaal L, Peet DJ, Weill J, Miller JL, Horber F, Goldstone AP, Driscoll DJ, Bruning JB, Meyre D, Whitelaw ML, Froguel P. Loss-of-function mutations in SIM1 contribute to obesity and Prader-Willi-like features. J Clin Invest. 2013 Jul 1;123(7):3037-41.

Bouchard C, Tremblay A, Després JP, Nadeau A, Lupien PJ, Thériault G, Dussault J, Moorjani S, Pinault S, Fournier G. The response to long-term overfeeding in identical twins. N Engl J Med. 1990 May 24;322(21):1477-82.

Bouchard C, Tremblay A, Després JP, Thériault G, Nadeau A, Lupien PJ, Moorjani S, Prudhomme D, Fournier G. The response to exercise with constant energy intake in identical twins. Obes Res. 1994 Sep;2(5):400-10.

Burns B, Schmidt K, Williams SR, Kim S, Girirajan S, Elsea SH. Rai1 haploinsufficiency causes reduced Bdnf expression resulting in hyperphagia, obesity and altered fat distribution in mice and humans with no evidence of metabolic syndrome. Hum Mol Genet. 2010 Oct 15;19(20):4026-42.

Calton ,MA, Vaisse, C. Narrowing down the role of common variants in the genetic predisposition to obesity. Genome Medicine. 2009 Mar,11 1:31. 
Carter MT, Nikkel SM, Fernandez BA, Marshall CR, Noor A, Lionel AC, Prasad A, Pinto D, Joseph-George AM, Noakes C, Fairbrother-Davies C, Roberts W, Vincent J, Weksberg R, Scherer SW. Hemizygous deletions on chromosome 1p21.3 involving the DPYD gene in individuals with autism spectrum disorder. Clin Genet. 2011 Nov;80(5):435-43.

Cassidy SB, Schwartz S, Miller JL, Driscoll DJ. Prader-Willi syndrome. Genet Med. 2012 Jan;14(1):10-26.

Chen CP, Huang HK, Ling PY, Su YN, Chen M, Tsai FJ, Wu PC, Chern SR, Chen YT, Lee CC, Wang W. A de novo duplication of chromosome 21q22.11 $\rightarrow$ qter associated with Down syndrome: prenatal diagnosis, molecular cytogenetic characterization and fetal ultrasound findings. Taiwan $\mathbf{J}$ Obstet Gynecol. 2011 Dec;50(4):492-8.

Choquet H, Meyre D. Genomic insights into early-onset obesity. Genome Med. 2010 Jun 23;2(6):36.

Coll, AP, Farooqi, IS, Challis, BG, Yeo, GSH, O'Rahilly, S. Proopiomelanocortin and Energy Balance: Insights from Human and Murine Genetics. The Journal of Clinical Endocrinology \& Metabolism. 2004 89(6):2557-2562.

Cooper GM, Coe BP, Girirajan S, Rosenfeld JA, Vu TH, Baker C, Williams C, Stalker H, Hamid R, Hannig V, Abdel-Hamid H, Bader P, McCracken E, Niyazov 
D, Leppig K, Thiese H, Hummel M, Alexander N, Gorski J, Kussmann J, Shashi V, Johnson K, Rehder C, Ballif BC, Shaffer LG, Eichler EE. A copy number variation morbidity map of developmental delay. Nat Genet. 2011 Aug 14;43(9):838-46.

Curran JE, McKay DR, Winkler AM, Olvera RL, Carless MA, Dyer TD, Kent JW Jr, Kochunov P, Sprooten E, Knowles EE, Comuzzie AG, Fox PT, Almasy L, Duggirala R, Blangero J, Glahn DC. Identification of pleiotropic genetic effects on obesity and brain anatomy. Hum Hered. 2013;75(2-4):136-43.

D’Angelo CS, Da Paz JA, Kim CA, Bertola DR, Castro CIE, Varela MC, Koiffmann CP. Prader-Willi-like phenotype: investigation of $1 \mathrm{p} 36$ deletion in 41 patients with delayed psychomotor development, hypotonia, obesity and/or hyperphagia, learning disabilities and behavioral problems. European $\mathbf{J}$ Medical Genetics. 2006 49(6):451-60.

D’Angelo CS, Kohl I, Varela MC, de Castro, CIE, Kim CA, Bertola DR, Lourenco $\mathrm{CM}$, Koiffmann CP. Extending the phenotype of monosomy 1p36 syndrome and mapping of a critical region for obesity and hyperphagia. Am J Med Genet Part A 2010 152A:102-110.

Deng $\mathrm{Y}$, Deng H, Bi F, Liu J, Bemis LT, Norris D, Wang XJ, Zhang Q. MicroRNA-137 targets carboxyl-terminal binding protein 1 in melanoma cell lines. Int J Biol Sci. 2011 Jan 27;7(1):133-7. 
Deutsch S, Lyle R, Dermitzakis ET, Attar H, Subrahmanyan L, Gehrig C, Parand L, Gagnebin M, Rougemont J, Jongeneel CV, Antonarakis SE. Gene expression variation and expression quantitative trait mapping of human chromosome 21 genes. Hum Mol Genet. 2005 Dec 1;14(23):3741-9.

de Vries, BBA, Pfundt, R, Leisink, M, Koolen, DA, Vissers,LELM, Janssen, IM, van Reijmersdal, S, Nillesen, WN, Huys, EHLPG, de Leeuw,N, Smeets, D, Sistermans, EA, Feuth, T, van Ravenswaaij-Arts, CMA, van Kessel, AG, Schoenmakers, EFPM, Brunner, HG, Veltman1, JA. Diagnostic Genome Profiling in Mental Retardation. Am. J. Hum. Genet. 2005 77:606-616.

Doco-Fenzy M, Leroy C, Schneider A, Petit F, Delrue MA, Andrieux J, PerrinSabourin L, Landais E, Aboura A, Puechberty J, Girard M, Tournaire M, Sanchez E, Rooryck C, Ameil A, Goossens M, Jonveaux P, Lefort G, Taine L, Cailley D, Gaillard D, Leheup B, Sarda P, Geneviève D. Early-onset obesity and paternal 2pter deletion encompassing the ACP1, TMEM18, and MYT1L genes. Eur J Hum Genet 2014 Apr;22(4):471-9.

Dorschner MO, Sybert VP, Weaver M, Pletcher BA, Stephens K. NF1 microdeletion breakpoints are clustered at flanking repetitive sequences. Human Molecular Genetics. 2000 9(1): 35-46.

Douglas, J., Cilliers, D., Coleman, K., Tatton-Brown, K., Barker, K., Bernhard, B., Burn, J., Huson, S., Josifova, D., Lacombe, D., Malik, M., Mansour, S., Reid, E., Cormier-Daire, V., Cole, T., The Childhood Overgrowth Collaboration, 
Rahman, N. Mutations in RNF135, a gene within the NF1 microdeletion region, causes phenotypic abnormalities including overgrowth. Nature Genet. 2007 39: 963-965.

Elsea SH, Williams SR. Smith-Magenis syndrome: haploinsufficiency of RAI1 results in altered gene regulation in neurological and metabolic pathways. Expert Rev Mol Med. 2011 Apr 19;13:e14.

Falk RE, Casas KA. Chromosome 2q37 deletion: clinical and molecular aspects. Am J Med Genet C Semin Med Genet. 2007 Nov 15;145C(4):357-71.

Farooqi, IS, O'Rahilly, S. Human Melanocortin 4 Receptor Deficiency. In: Genetics of Obesity Syndromes. New York: Oxford University Press, Inc., 2009. P.81-90.

Forsythe E1, Beales PL. Bardet-Biedl syndrome. Eur J Hum Genet. 2013 Jan;21(1):8-13.

Gijsbers AC, Lew JY, Bosch CA, Schuurs-Hoeijmakers JH, van Haeringen A, den Hollander NS, Kant SG, Bijlsma EK, Breuning MH, Bakker E, Ruivenkamp CA. A new diagnostic workflow for patients with mental retardation and/or multiple congenital abnormalities: test arrays first. Eur J Hum Genet. 2009 Nov; 17(11):1394-402. 
Girirajan S, Rosenfeld JA, Cooper GM, Antonacci F, Siswara P, Itsara A, Vives L, Walsh T, McCarthy SE, Baker C, Mefford HC, Kidd JM, Browning SR, Browning BL, Dickel DE, Levy DL, Ballif BC, Platky K, Farber DM, Gowans GC, Wetherbee JJ, Asamoah A, Weaver DD, Mark PR, Dickerson J, Garg BP, Ellingwood SA, Smith R, Banks VC, Smith W, McDonald MT, Hoo JJ, French BN, Hudson C, Johnson JP, Ozmore JR, Moeschler JB, Surti U, Escobar LF, El-Khechen D, Gorski JL, Kussmann J, Salbert B, Lacassie Y, Biser A, McDonald-McGinn DM, Zackai EH, Deardorff MA, Shaikh TH, Haan E, Friend KL, Fichera M, Romano C, Gécz J, DeLisi LE, Sebat J, King MC, Shaffer LG, Eichler EE. A recurrent 16p12.1 microdeletion supports a two-hit model for severe developmental delay. Nat Genet. 2010 Mar;42(3):203-9.

Girirajan S, Brkanac Z, Coe BP, Baker C, Vives L, Vu TH, Shafer N, Bernier R, Ferrero GB, Silengo M, Warren ST, Moreno CS, Fichera M, Romano C, Raskind WH, Eichler EE. Relative burden of large CNVs on a range of neurodevelopmental phenotypes. PLoS Genet. 2011 Nov;7(11):e1002334.

Goldlust IS, Hermetz KE, Catalano LM, Barfield RT, Cozad R, Wynn G, Ozdemir AC, Conneely KN, Mulle JG, Dharamrup S, Hegde MR, Kim KH, Angle B, Colley A, Webb AE, Thorland EC, Ellison JW, Rosenfeld JA, Ballif BC, Shaffer LG, Demmer LA; Unique Rare Chromosome Disorder Support Group, Rudd MK, Searle BA, Wynn SL. Mouse model implicates GNB3 duplication in a childhood obesity syndrome. Proc Natl Acad Sci U S A. 2013 Sep 10;110(37):14990-4. 
Goldstone AP, Beales PL. Genetic obesity syndromes. Front Horm Res. 2008 36:37-60.

Grisart B, Rack K, Vidrequin S, Hilbert P, Deltenre P, Verellen-Dumoulin C, Destrée A. NF1 microduplication first clinical report: association with mild mental retardation, early onset of baldness and dental enamel hypoplasia? European Journal of Human Genetics. 2008 16, 305-311.

Han JC, Liu QR, Jones M, Levinn RL, Menzie CM, Jefferson-George KS, AdlerWailes DC, Sanford EL, Lacbawan FL, Uhl GR, Rennert OM, Yanovski JA. Brain-derived neurotrophic factor and obesity in the WAGR syndrome. N Engl $\mathbf{J}$ Med. 2008 Aug 28;359(9):918-27.

Hannes FD, Sharp AJ, Mefford HC, de Ravel T, Ruivenkamp CA, Breuning MH, Fryns JP, Devriendt K, Van Buggenhout G, Vogels A, Stewart H, Hennekam RC, Cooper GM, Regan R, Knight SJ, Eichler EE, Vermeesch JR. Recurrent reciprocal deletions and duplications of $16 \mathrm{p} 13.11$ : the deletion is a risk factor for MR/MCA while the duplication may be a rare benign variant. J Med Genet. 2009 Apr;46(4):223-32.

Hastings PJ, Lupski JR, Rosenberg SM, Ira G. Mechanisms of change in gene copy number. Nat Rev Genet. 2009 Aug;10(8):551-64. 
Hebebrand J, Friedel S, Schäuble N, Geller F, Hinney A. Perspectives: molecular genetic research in human obesity. Obes Rev. 2003 Aug;4(3):13946.

Hebebrand J, Hinney A. Environmental and genetic risk factors in obesity. Child Adolesc Psychiatr Clin N Am. 2009 Jan;18(1):83-94.

Hebebrand J. Obesity. In: Martin A, Volkmar FR, Lewis M (eds) Lewis's Child and adolescent psychiatry: a comprehensive textbook. Lippincott Willians \& Wilkins, Philadelphia, pp 602-614, 2007.

Hehir-Kwa JY, Pfundt R, Veltman JA, de Leeuw N. Pathogenic or not? Assessing the clinical relevance of copy number variants. Clin Genet. 2013 Nov;84(5):415-21.

Herrera BM, Keildson S, Lindgren CM. Genetics and epigenetics of obesity. Maturitas. 2011 May;69(1):41-9.

Hinney A, Vogel Cl, Hebebrand J. From monogenic to polygenic obesity: recent advances. Eur Child Adolesc Psychiatry. 2010 Mar;19(3):297-310.

Holder JL Jr, Butte NF, Zinn AR. Profound obesity associated with a balanced translocation that disrupts the SIM1 gene. Hum Mol Genet. 2000 Jan $1 ; 9(1): 101-8$ 
Itsara A, Cooper GM, Baker C, Girirajan S, Li J, Absher D, Krauss RM, Myers RM, Ridker PM, Chasman DI, Mefford H, Ying P, Nickerson DA, Eichler EE. Population analysis of large copy number variants and hotspots of human genetic disease. Am J Hum Genet. 2009 Feb;84(2):148-61.

Jacquemont S, Reymond A, Zufferey F, Harewood L, Walters RG, Kutalik Z, Martinet D, Shen Y, Valsesia A, Beckmann ND, Thorleifsson G, Belfiore M, Bouquillon S, Campion D, de Leeuw N, de Vries BB, Esko T, Fernandez BA, Fernández-Aranda F, Fernández-Real JM, Gratacòs M, Guilmatre A, Hoyer J, Jarvelin MR, Kooy RF, Kurg A, Le Caignec C, Männik K, Platt OS, Sanlaville D, Van Haelst MM, Villatoro Gomez S, Walha F, Wu BL, Yu Y, Aboura A, Addor MC, Alembik Y, Antonarakis SE, Arveiler B, Barth M, Bednarek N, Béna F, Bergmann S, Beri M, Bernardini L, Blaumeiser B, Bonneau D, Bottani A, Boute O, Brunner HG, Cailley D, Callier P, Chiesa J, Chrast J, Coin L, Coutton C, Cuisset JM, Cuvellier JC, David A, de Freminville B, Delobel B, Delrue MA, Demeer B, Descamps D, Didelot G, Dieterich K, Disciglio V, Doco-Fenzy M, Drunat S, Duban-Bedu B, Dubourg C, El-Sayed Moustafa JS, Elliott P, Faas BH, Faivre L, Faudet A, Fellmann F, Ferrarini A, Fisher R, Flori E, Forer L, Gaillard D, Gerard M, Gieger C, Gimelli S, Gimelli G, Grabe HJ, Guichet A, Guillin O, Hartikainen AL, Heron D, Hippolyte L, Holder M, Homuth G, Isidor B, Jaillard S, Jaros Z, Jiménez-Murcia S, Helas GJ, Jonveaux P, Kaksonen S, Keren B, Kloss-Brandstätter A, Knoers NV, Koolen DA, Kroisel PM, Kronenberg F, Labalme A, Landais E, Lapi E, Layet V, Legallic S, Leheup B, Leube B, Lewis S, Lucas J, MacDermot KD, Magnusson P, Marshall C, Mathieu-Dramard M, McCarthy MI, Meitinger T, Mencarelli MA, Merla G, Moerman A, Mooser V, 
Morice-Picard F, Mucciolo M, Nauck M, Ndiaye NC, Nordgren A, Pasquier L, Petit F, Pfundt R, Plessis G, Rajcan-Separovic E, Ramelli GP, Rauch A, Ravazzolo R, Reis A, Renieri A, Richart C, Ried JS, Rieubland C, Roberts W, Roetzer KM, Rooryck C, Rossi M, Saemundsen E, Satre V, Schurmann C, Sigurdsson E, Stavropoulos DJ, Stefansson H, Tengström C, Thorsteinsdóttir U, Tinahones FJ, Touraine R, Vallée L, van Binsbergen E, Van der Aa N, Vincent-Delorme C, Visvikis-Siest S, Vollenweider P, Völzke H, Vulto-van Silfhout AT, Waeber G, Wallgren-Pettersson C, Witwicki RM, Zwolinksi S, Andrieux J, Estivill X, Gusella JF, Gustafsson O, Metspalu A, Scherer SW, Stefansson K, Blakemore Al, Beckmann JS, Froguel P. Mirror extreme BMI phenotypes associated with gene dosage at the chromosome $16 \mathrm{p} 11.2$ locus. Nature. 2011 Aug 31;478(7367):97-102.

Jankevicius G, Hassler M, Golia B, Rybin V, Zacharias M, Timinszky G, Ladurner AG. A family of macrodomain proteins reverses cellular mono-ADPribosylation. Nat Struct Mol Biol. 2013 Apr;20(4):508-14.

Jannot AS, Pelet A, Henrion-Caude A, Chaoui A, Masse-Morel M, Arnold S, Sanlaville D, Ceccherini I, Borrego S, Hofstra RM, Munnich A, Bondurand N, Chakravarti A, Clerget-Darpoux F, Amiel J, Lyonnet S. Chromosome 21 scan in Down syndrome reveals DSCAM as a predisposing locus in Hirschsprung disease. PLoS One. 2013 May 6;8(5):e62519.

Kearney HM, Thorland EC, Brown KK, Quintero-Rivera F, South ST; Working Group of the American College of Medical Genetics Laboratory Quality 
Assurance Committee. American College of Medical Genetics standards and guidelines for interpretation and reporting of postnatal constitutional copy number variants. Genet Med. $2011 \mathrm{Jul} ; 13(7): 680-5$.

Kirchhoff M, Bisgaard AM, Stoeva R, Dimitrov B, Gillessen-Kaesbach G, Fryns JP, Rose H, Grozdanova L, Ivanov I, Keymolen K, Fagerberg C, Tranebjaerg L, Skovby F, Stefanova M. Phenotype and 244k array-CGH characterization of chromosome 13q deletions: an update of the phenotypic map of 13q21.1-qter. Am J Med Genet A. 2009 May;149A(5):894-905.

Klenke S, Kussmann M, Siffert W. The GNB3 C825T polymorphism as a pharmacogenetic marker in the treatment of hypertension, obesity, and depression. Pharmacogenet Genomics. 2011 Sep;21(9):594-606.

Kohl, I. Pesquisa de genes e/ou segmentos cromossômicos em pacientes com obesidade e/ou hiperfagia, atraso do desenvolvimento neuropsicomotor e/ou dificuldades de aprendizado e distúrbios de comportamento. USP, 2010. 162p. Tese (Doutorado), Instituto de Biociências da Universidade de São Paulo, Departamento de Biologia. São Paulo, 2010.

Korbel JO, Tirosh-Wagner T, Urban AE, Chen XN, Kasowski M, Dai L, Grubert F, Erdman C, Gao MC, Lange K, Sobel EM, Barlow GM, Aylsworth AS, Carpenter NJ, Clark RD, Cohen MY, Doran E, Falik-Zaccai T, Lewin SO, Lott IT, McGillivray BC, Moeschler JB, Pettenati MJ, Pueschel SM, Rao KW, Shaffer LG, Shohat M, Van Riper AJ, Warburton D, Weissman S, Gerstein MB, Snyder 
M, Korenberg JR. The genetic architecture of Down syndrome phenotypes revealed by high-resolution analysis of human segmental trisomies. Proc Natl Acad Sci U S A. 2009 Jul 21;106(29):12031-6.

Kosaki R, Kosaki K, Matsushima K, Mitsui N, Matsumoto N, Ohashi H. Refining chromosomal region critical for Down syndrome-related heart defects with a case of cryptic 21q22.2 duplication. Congenit Anom (Kyoto). 2005 Jun;45(2):62-4.

Kousta, E, Hadjiathanasiou, CG, Tolis, G, Papathanasiou, A. Pleiotropic Genetic Syndromes with Developmental Abnormalities Associated with Obesity. Journal of Pediatric Endocrinology \& Metabolism, 2009 22, 581-592.

Krude, H, Grüters, A. Pro-opiomelanocortin Deficiency. In: Genetics of Obesity Syndromes. New York: Oxford University Press, Inc., 2009. P.49-62.

Kuniba H, Tsuda M, Nakashima M, Miura S, Miyake N, Kondoh T, Matsumoto T, Moriuchi $\mathrm{H}$, Ohashi $\mathrm{H}$, Kurosawa K, Tonoki H, Nagai T, Okamoto N, Kato M, Fukushima Y, Naritomi K, Matsumoto N, Kinoshita A, Yoshiura KI, Niikawa N. Lack of C20orf133 and FLRT3 mutations in 43 patients with Kabuki syndrome in Japan. J Med Genet. 2008 Jul;45(7):479-80.

Lana-Elola E, Watson-Scales SD, Fisher EM, Tybulewicz VL. Down syndrome: searching for the genetic culprits. Dis Model Mech. 2011 Sep;4(5):586-95. 
Leroy C, Landais E, Briault S, David A, Tassy O, Gruchy N, Delobel B, Grégoire MJ, Leheup B, Taine L, Lacombe D, Delrue MA, Toutain A, Paubel A, Mugneret F, Thauvin-Robinet C, Arpin S, Le Caignec C, Jonveaux P, Beri M, Leporrier N, Motte J, Fiquet C, Brichet O, Mozelle-Nivoix M, Sabouraud P, Golovkine N, Bednarek N, Gaillard D, Doco-Fenzy M. The 2q37-deletion syndrome: an update of the clinical spectrum including overweight, brachydactyly and behavioural features in 14 new patients. Eur J Hum Genet. 2013 Jun;21(6):602-12.

Lestner JM, Ellis R, Canham N. Delineating the 17q24.2-q24.3 microdeletion syndrome phenotype. Eur J Med Genet. 2012 Dec;55(12):700-4.

Lu X, Shaw CA, Patel A, Li J, Cooper ML, et al. Clinical Implementation of Chromosomal Microarray Analysis: Summary of 2513 Postnatal Cases. PLoS ONE 2007 2(3): e327.

Lupski JR. Genomic disorders ten years on. Genome Med. 2009 Apr $24 ; 1(4): 42$.

Lyle R, Béna F, Gagos S, Gehrig C, Lopez G, Schinzel A, Lespinasse J, Bottani A, Dahoun S, Taine L, Doco-Fenzy M, Cornillet-Lefèbvre P, Pelet A, Lyonnet S, Toutain A, Colleaux L, Horst J, Kennerknecht I, Wakamatsu N, Descartes M, Franklin JC, Florentin-Arar L, Kitsiou S, Aït Yahya-Graison E, Costantine M, Sinet PM, Delabar JM, Antonarakis SE. Genotype-phenotype correlations in 
Down syndrome identified by array CGH in 30 cases of partial trisomy and partial monosomy chromosome 21. Eur J Hum Genet. 2009 Apr;17(4):454-66

Ma, H, Shieh, KJ, Chen, G, Qiao, XT, Chuang, MY. Application of Real-time Polymerase Chain Reaction (RT-PCR). The Journal of American Science, $20062(3)$.

Maas NM, Van de Putte T, Melotte C, Francis A, Schrander-Stumpel CT, Sanlaville D, Genevieve D, Lyonnet S, Dimitrov B, Devriendt K, Fryns JP, Vermeesch JR. The C20orf133 gene is disrupted in a patient with Kabuki syndrome. J Med Genet. 2007 Sep;44(9):562-9.

Magoulas PL, Liu P, Gelowani V, Soler-Alfonso C, Kivuva EC, Lupski JR, Potocki L. Inherited dup(17)(p11.2p11.2): Expanding the phenotype of the Potocki-Lupski syndrome. Am J Med Genet A. 2014 Feb;164(2):500-4.

Mantripragada, KK, Buckley, PG, Stahl, TD, Dumanski, JP. Genomic microarrays in the spotlight. Trends Genet. 2004 Feb;20(2):87-94.

Margari L, Di Cosola ML, Buttiglione M, Pansini A, Buonadonna AL, Craig F, Cariola F, Petruzzelli MG, Gentile M. Molecular cytogenetic characterization and genotype/phenotype analysis in a patient with a de novo 8p23.2p23.3 deletion/12p13.31p13.33 duplication. Am J Med Genet. 2012 Part A 158A:1713-1718. 
Marshall CR, Noor A, Vincent JB, Lionel AC, Feuk L, Skaug J, Shago M, Moessner R, Pinto D, Ren Y, Thiruvahindrapduram B, Fiebig A, Schreiber S, Friedman J, Ketelaars CE, Vos YJ, Ficicioglu C, Kirkpatrick S, Nicolson R, Sloman L, Summers A, Gibbons CA, Teebi A, Chitayat D, Weksberg R, Thompson A, Vardy C, Crosbie V, Luscombe S, Baatjes R, Zwaigenbaum L, Roberts W, Fernandez B, Szatmari P, Scherer SW. Structural variation of chromosomes in autism spectrum disorder. Am J Hum Genet. 2008 Feb;82(2):477-88.

Moles KJ, Gowans GC, Gedela S, Beversdorf D, Yu A, Seaver LH, Schultz RA, Rosenfeld JA, Torchia BS, Shaffer LG. NF1 microduplications: identification of seven nonrelated individuals provides further characterization of the phenotype. Genet Med. 2012 14(5):508-514.

Møller RS, Kübart S, Hoeltzenbein M, Heye B, Vogel I, Hansen CP, Menzel C, Ullmann R, Tommerup N, Ropers HH, Tümer Z, Kalscheuer VM. Truncation of the Down syndrome candidate gene DYRK1A in two unrelated patients with microcephaly. Am J Hum Genet. 2008 May;82(5):1165-70.

Morris B, Etoubleau C, Bourthoumieu S, Reynaud-Perrine S, Laroche C, Lebbar A, Yardin C, Elsea SH. Dose dependent expression of HDAC4 causes variable expressivity in a novel inherited case of brachydactyly mental retardation syndrome. Am J Med Genet A. 2012 Aug;158A(8):2015-20. 
Murphy A, Tantisira KG, Soto-Quirós ME, Avila L, Klanderman BJ, Lake S, Weiss ST, Celedón JC. PRKCA: a positional candidate gene for body mass index and asthma. Am J Hum Genet. 2009 Jul;85(1):87-96.

Mutch DM, Clément K. Unraveling the genetics of human obesity. PLoS Genet 2006 2(12): e188.

Ou Z, Stankiewicz P, Xia Z, Breman AM, Dawson B, Wiszniewska J, Szafranski P, Cooper ML, Rao M, Shao L, South ST, Coleman K, Fernhoff PM, Deray MJ, Rosengren S, Roeder ER, Enciso VB, Chinault AC, Patel A, Kang SH, Shaw CA, Lupski JR, Cheung SW. Observation and prediction of recurrent human translocations mediated by NAHR between nonhomologous chromosomes. Genome Res. 2011 Jan;21(1):33-46.

Park J, Oh Y, Yoo L, Jung MS, Song WJ, Lee SH, Seo H, Chung KC. Dyrk1A phosphorylates p53 and inhibits proliferation of embryonic neuronal cells. J Biol Chem. 2010 Oct 8;285(41):31895-906.

Peñagarikano $\mathrm{O}$, Geschwind $\mathrm{DH}$. What does CNTNAP2 reveal about autism spectrum disorder? Trends Mol Med. 2012 Mar;18(3):156-63.

Quélin C, Bendavid C, Dubourg C, de la Rochebrochard C, Lucas J, Henry C, Jaillard S, Loget P, Loeuillet L, Lacombe D, Rival JM, David V, Odent S, Pasquier L. Twelve new patients with $13 q$ deletion syndrome: genotypephenotype analyses in progress. Eur J Med Genet. 2009 Jan-Feb;52(1):41-6. 
Rio M, Royer G, Gobin S, de Blois MC, Ozilou C, Bernheim A, Nizon M, Munnich A, Bonnefont JP, Romana S, Vekemans M, Turleau C, Malan V. Monozygotic twins discordant for submicroscopic chromosomal anomalies in 2p25.3 region detected by array CGH. Clin Genet. 2013 Jul;84(1):31-6.

Roberson ED, Wohler ES, Hoover-Fong JE, Lisi E, Stevens EL, Thomas GH, Leonard J, Hamosh A, Pevsner J. Genomic analysis of partial 21q monosomies with variable phenotypes. Eur J Hum Genet. 2011 Feb;19(2):235-8.

Rodríguez-López R, Pérez JM, Balsera AM, Rodríguez GG, Moreno TH, García de Cáceres M, Serrano MG, Freijo FC, Ruiz JR, Angueira FB, Pérez PM, Estévez MN, Gómez EG. The modifier effect of the BDNF gene in the phenotype of the WAGRO syndrome. Gene. 2013 Mar 10;516(2):285-90.

Ronan A, Fagan K, Christie L, Conroy J, Nowak NJ, Turner G. Familial 4.3 Mb duplication of 21q22 sheds new light on the Down syndrome critical region. BMJ Case Rep. 2009 Jun 4.

Sahoo T, Theisen A, Rosenfeld JA, Lamb AN, Ravnan JB, Schultz RA, Torchia BS, Neill N, Casci I, Bejjani BA, Shaffer LG. Copy number variants of schizophrenia susceptibility loci are associated with a spectrum of speech and developmental delays and behavior problems. Genet Med. 2011 Oct;13(10):868-80. 
Scheidecker S1, Etard C, Pierce NW, Geoffroy V, Schaefer E, Muller J, Chennen K, Flori E, Pelletier V, Poch O, Marion V, Stoetzel C, Strähle U, Nachury MV, Dollfus H. Exome sequencing of Bardet-Biedl syndrome patient identifies a null mutation in the BBSome subunit BBIP1 (BBS18). J Med Genet. 2014 Feb;51(2):132-6.

Schmittgen, TD, Livak, KJ. Analyzin real-time PCR data by the comparative $\mathrm{C}_{\mathrm{T}}$ method. Nat Protoc. 2008 3(6):1101-8.

Shinawi M, Sahoo T, Maranda B, Skinner SA, Skinner C, Chinault C, Zascavage R, Peters SU, Patel A, Stevenson RE, Beaudet AL. 11p14.1 microdeletions associated with ADHD, autism, developmental delay, and obesity. Am J Med Genet A. 2011 Jun;155A(6):1272-80.

Slater, HR, Bailey, DK, Ren, H, Cao, M, Bell, K, Nasioulas, S, Henke, R, Choo, KHA, Kennedy, GC. High-Resolution Identification of Chromosomal Abnormalities Using Oligonucleotide Arrays Containing 116,204 SNPs. Am. J. Hum. Genet. 2005 Nov;77(5):709-26.

Speliotes E. K., Willer C. J., Berndt S. I et al. Association analyses of 249,796 individuals reveal 18 new loci associated with body mass index. Nature Genetics, 2010 42: 937-948. 
Stankiewicz P, Pursley AN, Cheung SW. Challenges in clinical interpretation of microduplications detected by array CGH analysis. Am J Med Genet A. 2010 May;152A(5):1089-100.

Stevens SJ, van Ravenswaaij-Arts CM, Janssen JW, Klein Wassink-Ruiter JS, van Essen AJ, Dijkhuizen T, van Rheenen J, Heuts-Vijgen R, Stegmann AP, Smeets EE, Engelen JJ. MYT1L is a candidate gene for intellectual disability in patients with 2p25.3 (2pter) deletions. Am J Med Genet A. 2011 Nov;155A(11):2739-45.

Toriello $\mathrm{H}$, Mathew M, Valdmanis $\mathrm{V}$. Evidence that macrocephaly and obesity may be dependent traits. Am J Med Genet A. 2007 Dec 15;143A(24):3035-7

van Es MA, van Vught PW, Blauw HM, Franke L, Saris CG, Van den Bosch L, de Jong SW, de Jong V, Baas F, van't Slot R, Lemmens R, Schelhaas HJ, Birve A, Sleegers K, Van Broeckhoven C, Schymick JC, Traynor BJ, Wokke JH, Wijmenga C, Robberecht W, Andersen PM, Veldink JH, Ophoff RA, van den Berg LH. Genetic variation in DPP6 is associated with susceptibility to amyotrophic lateral sclerosis. Nature Genet. 2008 Jan;40(1):29-31.

van Kuilenburg AB, Meijer J, Mul AN, Hennekam RC, Hoovers JM, de DieSmulders CE, Weber P, Mori AC, Bierau J, Fowler B, Macke K, Sass JO, Meinsma R, Hennermann JB, Miny P, Zoetekouw L, Vijzelaar R, Nicolai J, Ylstra B, Rubio-Gozalbo ME. Analysis of severely affected patients with dihydropyrimidine dehydrogenase deficiency reveals large intragenic 
rearrangements of DPYD and a de novo interstitial deletion del(1)(p13.3p21.3). Hum Genet. 2009 Jun;125(5-6):581-90.

Varela MC, Kok F, Setian N, Kim CA, Koiffmann CP. Impact of molecular mechanisms, including deletion size, on Prader-Willi syndrome phenotype: study of 75 patients. Clin Genet 2005 67: 47-52.

Venturin M, Guarnieri P, Natacci F, Stabile M, Tenconi R, Clementi M, Hernandez C, Thompson P, Upadhyaya M, Larizza L, Riva P. Mental retardation and cardiovascular malformations in NF1 microdeleted patients point to candidate genes in 17q11.2. J Med Genet. 2004 41:35-41.

Vergult S, Dauber A, Delle Chiaie B, Van Oudenhove E, Simon M, Rihani A, Loeys B, Hirschhorn J, Pfotenhauer J, Phillips JA 3rd, Mohammed S, Ogilvie C, Crolla J, Mortier G, Menten B. 17q24.2 microdeletions: a new syndromal entity with intellectual disability, truncal obesity, mood swings and hallucinations. Eur J Hum Genet. 2012 May;20(5):534-9.

Vignoli A, Scornavacca GF, Peron A, La Briola F, Canevini MP. Interstitial 6q microdeletion syndrome and epilepsy: a new patient and review of the literature. Am J Med Genet A. 2013 Aug;161A(8):2009-15.

Vissers, LELM, de Vries, BBA, Osoegawa, K, Janssen, IM, Feuth, T, Choy, CO, Straatman, H, van der Vliet, W, Huys, EHLPG, van Rijk, A, Smeets, D, van Ravenswaaij-Arts, CMA, Knoers, NV, van der Burgt, I, Jong, PJ, Brunner, HG, 
van Kessel, AG, Schoenmakers,EFPM, Veltman, JA. Array-Based Comparative Genomic Hybridization for the Genomewide Detection of Submicroscopic Chromosomal Abnormalities. Am. J. Hum. Genet. 2003 Dec;73(6):1261-70.

Whitley P, Gibbard AM, Koumanov F, Oldfield S, et al. Identification of centaurin- $\alpha 2$ : A phosphatidylinositide-binding protein present in fat, heart and skeletal muscle. European Journal of Cell Biology. 2002 Apr 81:222-230.

Willemsen MH, Valle`s A, Kirkels LAMH, Mastebroek M, Loohuis NO, Kos A, Wissink-Lindhout WM, de Brouwer APM, Nillesen WM, Pfundt R, HolderEspinasse M, Vallée L, Andrieux J, Coppens-Hofman MC, Rensen H, Hamel BCJ, van Bokhoven H, Aschrafi A, Kleefstra T. Chromosome 1p21.3 microdeletions comprising DPYD and MIR137 are associated with intellectual disability. J Med Genet. 2011 48:810-818.

Willemsen MH, Vulto-van Silfhout AT, Nillesen WM, Wissink-Lindhout WM, van Bokhoven H, Philip N, Berry-Kravis EM, Kini U, van Ravenswaaij-Arts CM, Delle Chiaie B, Innes AM, Houge G, Kosonen T, Cremer K, Fannemel M, StrayPedersen A, Reardon W, Ignatius J, Lachlan K, Mircher C, Helderman van den Enden PT, Mastebroek M, Cohn-Hokke PE, Yntema HG, Drunat S, Kleefstra T. Update on Kleefstra Syndrome. Mol Syndromol. 2012 Apr;2(3-5):202-212.

Williams SR, Aldred MA, Der Kaloustian VM, Halal F, Gowans G, McLeod DR, Zondag S, Toriello HV, Magenis RE, Elsea SH. Haploinsufficiency of HDAC4 
causes brachydactyly mental retardation syndrome, with brachydactyly type E, developmental delays, and behavioral problems. Am J Hum Genet. 2010 Aug 13;87(2):219-28.

Wright C, Turner JA, Calhoun VD, Perrone-Bizzozero N. Potential Impact of miR-137 and Its Targets in Schizophrenia. Front Genet. 2013 Apr 26;4:58.

Yamamoto T, Togawa M, Shimada S, Sangu N, Shimojima K, Okamoto N. Narrowing of the responsible region for severe developmental delay and autistic behaviors in WAGR syndrome down to $1.6 \mathrm{Mb}$ including PAX6, WT1, and PRRG4. Am J Med Genet A. 2014 Mar;164(3):634-8.

Zhang Y, Smith EM, Baye TM, Eckert JV, Abraham LJ, Moses EK, Kissebah AH, Martin LJ, Olivier M. Serotonin (5-HT) receptor 5A sequence variants affect human plasma triglyceride levels. Physiol Genomics. 2010 Jul 7;42(2):168-76. 